\title{
UMA ANÁLISE DA PROTEÇÃO EFETIVA NA AGRICULTURA DO ESTADO DE SÃO PAULO
}

\author{
FERNANDO NAVES BLUMENSCHEIN
}

Orientador: Prof. Dr. FERNANDO B. HOMEM DE MELO

Dissertação apresentada à Escola Superior de Agricultura "Luiz de Queiroz", da Universidade de São Paulo, para obtenção do título de Mestre em Agronomia. Área de

Concentração: Economia Agrária.

PIRACICABA

Estado de São Paulo - Brasil

Novembro, 1982 
Ao pesquisar, pode-se e deve-se ser criativo e rigoroso ao mesmo tempo. Não respeitar o rïgor é não respeitar a ciência. Não respeitar a criatividade ē tolher o cientista.

Aos avös, Fermando e Francisco, raízes que não conheci, e à minha fomitia, que me acompanhou. 
iii.

\section{AGRADECIMENTOS}

Sou grato a todas as pessoas que souberam contribuir para minha formação acadêmica. A elas dedico respeito, e as tenho comigo. 
Päg.

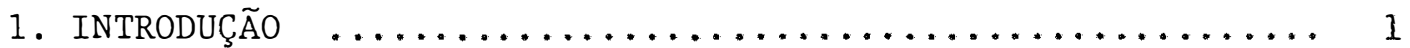

2. REVISÃO DE LITERATURA E OBJETIVOS $\ldots \ldots \ldots \ldots \ldots \ldots \ldots \ldots . \ldots$

2.1 - Argumentos Sobre a Discriminação do Setor Agrícola .. 4

2.2 - Tecnologia e Discriminação ................ 15

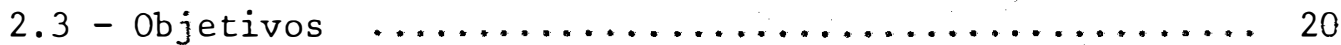

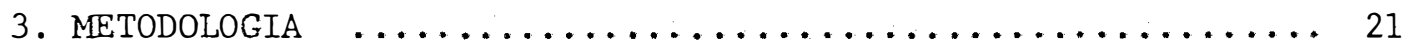

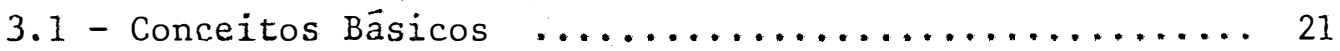

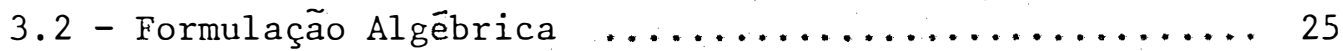

3.3 - Método de Cálculo .......................... 28

3.4 - Insumos Não Comercializāveis ("Non-Tradable") . . . . 31

3.5 - Considerações Sobre a Implementação da Análise .... 32

4. DESCRIÇÃO DOS DADOS UTILIZADOS $\ldots \ldots \ldots \ldots \ldots \ldots \ldots \ldots \ldots$

4.1 - Período, Produto e Região Analisados ........... 36

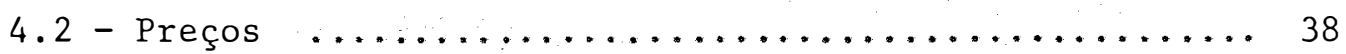

4.2 .1 - Preço dos produtos ............... 38

4.2 .2 - Preço dos fertilizantes ............ 42

4.2 .3 - Preço dos derivados do petróleo ........ 45

4.2 .4 - Custo de transporte $\ldots \ldots \ldots \ldots \ldots \ldots \ldots \ldots 48$

4.3 - Coeficientes Tëcnicos ................... 50

4.3.1 - Nota sobre o conceito de custo de produção do

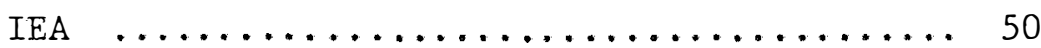




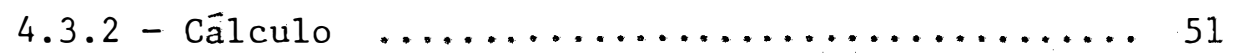

4.3 .3 - Ajuste para diesel e graxa $\ldots \ldots \ldots \ldots \ldots \ldots$

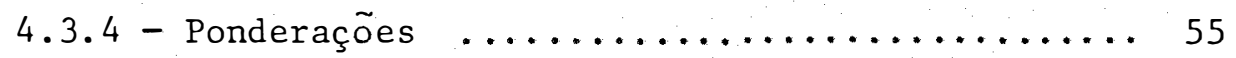

5. RESULTADOS E DISCUSSÃO $\ldots \ldots \ldots \ldots \ldots \ldots \ldots \ldots \ldots \ldots \ldots \ldots \ldots \ldots \ldots \ldots \ldots \ldots$

5.1 - Custo Diärio de Tratores e Custo de Produção ...... 62

5.2 - Taxa de Proteção Efetiva (TPE) $\ldots \ldots \ldots \ldots \ldots \ldots \ldots 66$

5.2 .1 - Custo de transporte .............. 83

5.3 - Tecnologia e Taxação da Agricultura ........... 87

5.4 - Disponibilidade de Tecnologia por Produto para São Pau

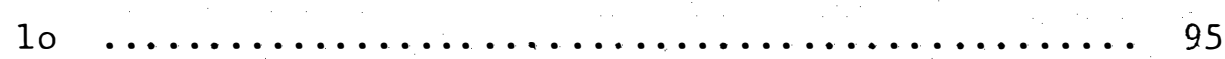

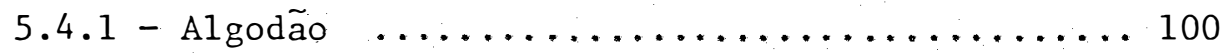

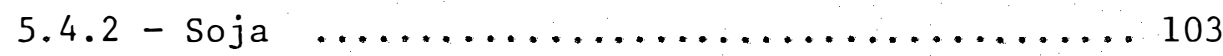

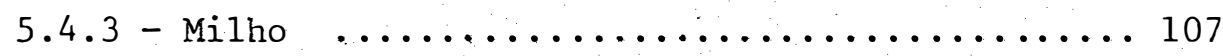

5.4 .4 - Arroz e feijão ..................111

5.5 - Proteção Efetiva e Tecnologia ................ 115

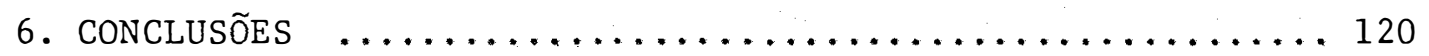

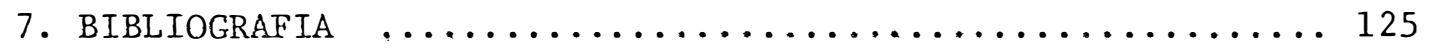

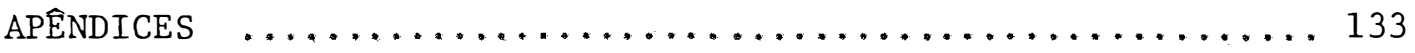




\section{LISTA DE TABELAS}

TABELA

Pàg.

1 Preços correntes mëdios recebidos pelos produtores. São Paulo, 1968-1978. Cr\$/ton ............. 40

2 Preços médios de exportaçäo. Cr\$/ton. 1968 a 1978..

3 Preços anuais mëdios dos nutrientes $\mathrm{N}, \mathrm{P}_{2} \mathrm{O}_{5}, \mathrm{~K}_{2} \mathrm{O}$ pa gos pelos agricultores do Estado de São Paulo. Cr $\$ 1$ kg. 1968 a 1980 .......................

4 Preços anuais médios de importação dos nutrientes $\mathrm{N}$, $\mathrm{P}_{2} \mathrm{O}_{5}$ e $\mathrm{K}_{2} \mathrm{O}$. Cr $\$ /$ ha. 1968 a $1980 \ldots \ldots \ldots \ldots \ldots \ldots \ldots 44$

5 Preços internos e externos de öleo diesel e graxa. Médias anuais. 1968 a 1978 ..................

6 Preços médios anuais de venda no mercado atacadista, cidade de São Paulo, 1968 a 1978. Cr\$/ton .......

7 Coeficientes físicos de consumo de ỏleo diesel e gra

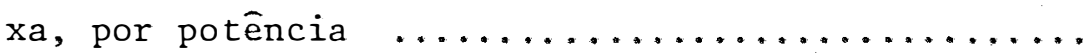

8 Arroz beneficiado. Coeficientes técnicos ponderados, em unidade de insumos por tonelada de produto. São Paulo. 1970/71 - 1979/80 .................

9 Algodão em pluma. Coeficientes técnicos ponderados, em unidades de insumos por tonelada de produto. São

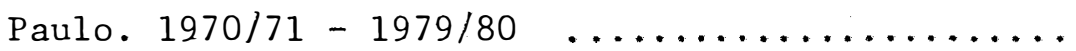


vii.

TABELA

Pàg.

10 Feijão. Coeficientes técnicos ponderados, em unidades de insumos por tonelada de produto. São Paulo.

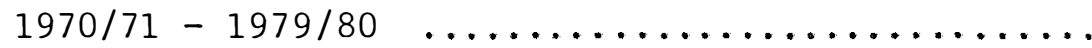

11 Milho. Coeficientes técnicos ponderados, em unidades de insumos por tonelada de produto. São Paulo. $1970 / 71-1979 / 80 \quad \ldots \ldots \ldots \ldots \ldots \ldots \ldots \ldots \ldots$

12 Soja. Coeficientes técnicos ponderados, em unidade de insumos por tonelada de produto. São Paulo. 1970/

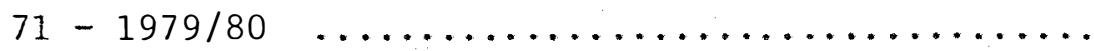

13 Participação percentual dos diversos ítens no custo diário de tratores de quatro rodas, segundo a potên cia (HP). São Paulo. 1970/71 - 1980/81 ........

14 Algodão. Tarifa de proteção efetiva (TPE) e proteção nominal (PN). São Paulo. 1968-1978 ......... 70

15 Arroz. Tarifa de proteção efetiva (TPE) e proteção nominal (PN). São Paulo. 1968-1978 ............

16 Feijão. Tarifa de proteção efetiva (TPE) e proteção nominal (PN). São Paulo. 1968-1978 ...........

17 Milho. Tarifa de proteção efetiva (TPE) e proteção nominal (PN). São Paulo, 1968-1978 ........... 
viii.

TABELA

Pág.

18 Soja. Tarifa de proteção efetiva (TPE) e proteção no minal (PN). São Paulo. 1968-1978 .............. 74

19 Tarifa de Proteção Efetiva (TPE) e Proteção Nominal (PN), com a inclusão dos custos de transporte. São Paulo. 1968 a 1978 .......................

20 Area cultivada e produtividade. Médias trienais. 1967/69 - 1979/80. Brasil .................

21 Taxa de crescimento da produção agrícola brasileira. Cinco produtos. 1967/76 e 1970/79 ..............

22 Distribuição por produto das publicações de pesquisa do Instituto Agronômico de Campinas (Revista Bragan-

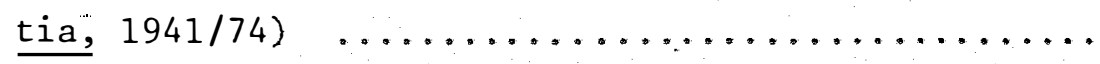

23 Nủmero de artigos científicos em pesquisa agrícola publicados em São Paulo, segundo o produto. 1927-77

24 Variedades de algodão lançadas pelo IAC, suas origens e ëpocas ............................ 101

25 Principais cultivares de soja, seus períodos e acrës cimos na produtividade .................... 104

26 Ganhos médios de produtividade de três cultivares de soja, devido ao uso de tecnologias mais avançadas no manejo do solo e da cultura, a partir de experimentos em Passo Fundo, Rs $\ldots \ldots \ldots \ldots \ldots \ldots \ldots \ldots \ldots$ 
27 Epoca e descrição dos principais eventos de pesquisa

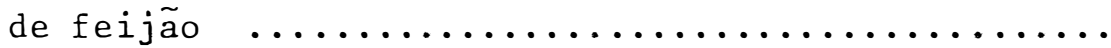

28 Participação porcentual de fertilizantes, defensivos e trator de rodas no custo de produção de arroz. São Paulo. 1970/71 - 1979/80

29 Participação de defensivos, fertilizantes e trator de rodas no custo de produção de algodão. São Paulo. $1970 / 71-1979 / 80$

30 Participação de fertilizantes, defensivos e trator de rodas no custo de produção de feijão. São Paulo. $1970 / 71-1979 / 80$

31 Participação de defensivos, fertilizantes e trator de rodas no custo de produção de milho. São Paulo. $1970 / 71-1979 / 80$

32 Participação de defensivos, fertilizantes e trator de rodas no custo de produção da soja. São Paulo. $1970 / 71-1979 / 80$

33 Relação preço mínimo do algodão em pluma/preço mỉnimo algodão em caroço (PMAP/PMAC). Aproximação do cus to de beneficiamento $\ldots \ldots \ldots \ldots \ldots \ldots \ldots \ldots \ldots$

34 Custo de beneficiamento de arroz. Região Centro-Sul. 1968-1980 
35 Teor de nutrientes $\left(\mathrm{N}, \mathrm{P}_{2} \mathrm{O}_{5}\right.$ e $\left.\mathrm{K}_{2} \mathrm{O}\right)$ nos fertilizantes sulfato de amônio, superfosfato simples, superfosfa-

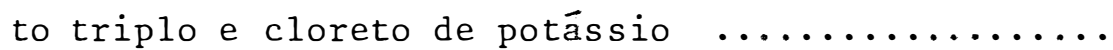

36 Vendas de tratores de quatro rodas no Brasil, segundo a faixa de potência. 1970-1979 ............. 145

37 Participação porcentual dos Estados Unidos na importação de defensivos (toneladas e valor em dōlares) pelo Brasil. 1968-1980 .................. 146

38 Produção e importação de superfosfato simples e superfosfato triplo. Brasil. 1968-1980. Em toneladas..

39 Taxa de câmbio ponderada. Brasil. 1968-1980 ...... 148

40 Consumo base de óleo diesel em um dia máquina. 19701979 .................................... 


\section{LISTA DE FIGURAS}

1 Arroz e feijão. Tarifa de Proteção Efetiva (TPE). 1968-1978

2 Soja, algodão e milho. Tarifa de Proteção Efetiva (TPE) . 1968-1978 
xii.

\title{
UMA ANĀLISE DA PROTEÇÃO EFETIVA NA AGRICULTURA DO ESTADO DE SÃO PAULO
}

\author{
Autor: $\quad$ Fernando Naves Blumenschein \\ Orientador: Prof. Dr. Fernando B. Homem de Melo
}

\section{$R E S \cup M O$}

O processo de taxação ou discriminação do setor agrícola brasileiro foi o problema central desse estudo. Este proble ma foi abordado em três níveis distintos. Primeiro, ao nível de pro duto, procurando caracterizar as taxações impostas aos agricultores via preços recebidos. Segundo, ao nível de insumos, na medida em que o processo de substituição de importações de alguns desses insumos gerou preços pagos pelos agricultores maiores que os que prevaleceram no mercado internacional. Por ūltimo, ao nível de tecnologias ge radas, visto que o processo de modernização tem a capacidade de aumentar a rentabilidade das culturas pela redução dos custos e aumen to da produtividade.

$$
\begin{array}{r}
\text { Pesquisaram-se cinco culturas, sendo duas do subse } \\
\text { tor doméstico (arroz e feijão), duas de exportação (soja e algodão) }
\end{array}
$$


e uma intermediäria (milho). Os aspectos de taxação via preço dos produtos e via preço dos insumos foram analisados pela Teoria da Pro teção Efetiva, através do cômputo de Tarifas de Proteção Efetiva e Proteção Nominal. Essas tarifas foram calculadas para o Estado de São Paulo no período de dez anos, compreendido entre 1968 e 1978. 0 aspecto tecnológico foi abordado atravēs de uma revisão dos traba Thos que quantificaram e qualificaram as disparidades tecnológicas entre os produtos em questão.

Ficou evidente que, apesar de alguns poucos produtos, e alguns anos do período apresentarem proteções ao nível de pre ço recebido, todos tiveram uma taxação ditada pelos insumos na forma de preços pagos mais elevados. Por outro lado, a natureza desequilibrada da geração de novas tecnologias beneficiou alguns produtos, notadamente os de exportação, enquanto os de mercado interno ficaram em atraso. De maneira geral, pode-se argumentar que as taxa ções não incidiram de maneira homogênea sobre os produtos estudados, e que estas taxações tiveram influência no crescimento de suas produções e produtividades.

De outra forma, foi questionado a importância de alguns instrumentos de política, como crédito rural subsidiado e o subsídio a insumos, na compensação das taxações sofridas pelo setor agrícola. A priori, estes instrumentos parecem menos eficientes em proteger a agricultura quando analisados num período de tempo maior e quando enfocados seus aspectos distributivos. Entretanto, outros 
xiv.

estudos são necessārios para que esses instrumentos sejam incorpora dos e a análise se amplie. 


\section{A ANALYSIS OF EFFECTIVE PROTECTION IN AGRICULTURE OF STATE OF SATO PAULO}

Author: $\quad$ Fernando Naves Blumenschein

Adviser: Prof. Dr. Fernando B. Homem de Melo

\section{$S U M M A R Y$}

The central aim of this research was to investigate the process of taxation or discrimination against the Brazilian agri cultural sector. This issue was analyzed at three different levels. First, it was analyzed at the output level in an effort to characte rize the taxes imposed on farmers by the prices received for agricultural products. Second, it was evaluated at the input level owing to the fact that the process of import substitution for some agricultural inputs forced farmers to pay more than the foreing market prices for the domestic import substitutes. Last, it was analyzed, at the technological level, since the process of agricultural modernization can lead to increases in the profitability of crops through both the reduction of production costs and of increases in agricultural productivity. 
xvi.

The analysis was conducted on five crops including, two domestic market crops (rice and beans), two export crops (soybeans and cotton) and one intermediate crop (corn). In respect to taxation, prices received and paid were analyzed using the theory of Effective Protection which involve the estimation of both effective protection tax and the nominal protection tax. These taxes were computed for the State of São Paulo from 1968 to 1978. The technological aspect of the study was investigated through the review of specific researches which quantified and qualified differences between crops analyzed.

It was elucidated that, although some of the crops during specific years were protected by the level of prices received for all of the crops analyzed farmers were taxed since they paid higher prices for agricultural inputs as compared with the current foreing market prices. On the other hand, the uniqueness is the process of generating new technologies benefited the export crops rather than the domestic crops. Generally speaking, it can be argued that taxation did not affect the different groups of crops equally, and consequently, it influenced differently the growth of their outputs and productivities.

Furthermore the importance of some economic policies, e.g., subsidized credits and subsidies for inputs were investigated as a means of offsetting the taxes imposed in the agricultural setor. A priori these policies seemed to be less effective in protect- 
xvii.

ing the agricultural sector when the analysis was extended for the whole period, as well as, when their distributive effects were considered. Nevertheless, more research is needed to properly analyze how these economic policies affected the agricultural sector. 
1. INTRODUÇAOO

\author{
Os termos discriminação e taxação, usados como sinô- \\ nimos nesta pesquisa, se referem a uma desproteção relativa do se- \\ tor agrícola em confronto com o setor industrial em razão dos obje- \\ tivos de política de desenvolvimento econômico seguida por muitos \\ países latino-americanos e, no nosso caso específico, o Brasil. \\ Esse objetivo de desenvolvimento, que se fez sentir \\ com intensidade após a II Guerra Mundial, concentrou-se primeiramen \\ te numa industrialização via substituição de importações. Esse pro- \\ cesso consistiu em dar condições para que muitas indústrias aqui se \\ instalassem e que tivessem um mercado para seus produtos. A competi \\ vidade dos setores que se iniciavam, pela sua característica de "in \\ düstria nascente", teve que ser assegurada por intermédio de värios \\ instrumentos de política fiscal, cambial, inclusive envolvendo fi- \\ nanciamentos e subsídios diversos.
}


Este modelo de desenvolvimento foi implementado, com ênfase, até a primeira metade da década dos sessenta, quando a ōtica principal passou a ser uma maior abertura da economia brasileira ao exterior, pela promoção das exportações. Mais uma vez o setor in dustrial teve um novo impulso, visto que o aumento da produção dos manufaturados foi o carro-chefe do aumento das exportações.

A distinção entre os dois períodos, em termos do modelo de desenvolvimento, è verdadeira em uma anālise agregada, mas não se deve esquecer que o processo de substituição de importações continuou para alguns setores da indūstria.

Neste segundo período, também se lançou mão de instrumentos de política específicos, tais como os incentivos fiscais e creditícios, os quais tiveram um papel importante naquela expansäo.

Dentro desses dois períodos específicos, é o argumen to de värios autores que o setor agrícola teria sido taxado. Em pri meiro lugar, a política comercial para os produtos agrícolas, voltada para os objetivos industriais, teria tido como consequência uma menor remuneração aos agricultores em relação aos preços no mercado internacional. Em adição, a proteção dada para os setores industriais produtores de insumos agrícolas modernos teria elevado os pre ços pagos pelos agricultores acima daqueles que prevaleceriam caso tivessem um mercado mais livre para importações.

Essa taxação dupla sofrida pelo setor agropecuáriote rỉa seus desmembramentos negativos para o crescimento, modernização 
agrícola e abastecimento do mercado interno.

Este estudo tem como objetivo investigar estas duas facetas da taxação, quais sejam, a baixa remuneração dos produtos e altos custos dos insumos. Na análise dessas questões se reportarâ o aspecto da geração de tecnologia pelo setor püblico entre os diversos produtos agrícolas, para que um terceiro elemento de taxação se ja incorporado à análise. 
4.

\section{REVISAOO DE LITERATURA E OBJETIVOS}

\section{1 - Argumentos Sobre a Discriminação do Setor Agrĩcola}

Apōs a II Guerra Mundia1, vārios países latino-ameri canos, procurando romper o subdesenvolvimento, optaram por uma poli tica de industrialização fundamentada no processo de substituição de importações. No Brasil, esta polîtica foi implementada, com ênfa se, desde a II Guerra:até por volta de 1964. Mesmo depois deste período, alguns setores tiveram neste processo a causa principal de seu crescimento. Um exemplo típico é o setor de fertilizantes que, atê na década dos setenta, ainda se encontrava num processo de subs tituição de importações. (1)

(1) BAUM (1977) descreve e questiona o processo de substituição de importações no setor de fertilizantes. Veja também, para uma anälise mais recente do setor de fertilizantes, BARRos et alii (1980). 
A característica básica deste processo de industrialização foi a série de instrumentos de política que beneficiaram o setor secundārio na sua implantação e crescimento. Dentre esses ins trumentos, pode-se citar ${ }^{(2)}$ : 1) tarifas e/ou controles de câmbio; 2) tratamento preferencial na importação de bens de capital para no vas indústrias; 3) taxas de câmbio preferenciais na importação de matérias primas industriais, petrōleo e bens intermediārios; 4) financiamentos subsidiados por bancos de desenvolvimento para indústrias favorecidas; 5) financiamento pelo setor püblico de infra-estrutura, visando à expansão do setor industrial; 6) participação di reta do estado em alguns setores industriais.

Por detrás desta industrialização estavam os objetivos de independência em relação aos países mais desenvolvidos, de crescimento acelerado $^{(3)}$ e modernização da economia. Como consequên cia, neste período o País experimentou uma urbanização acelerada com altas taxas de crescimento industrial. Por outro lado, tivemos uma agricultura crescendo de maneira modesta, e atingindo níveis insatisfatörios no crescimento da produtividade de seus fatores (4). Além disso, no final da década dos setenta, tínhamos a renda "per capita"

(2) Tirado de LOPES e SCHUH (1978). Detalhes das épocas que prevale ceram os diversos instrumentos existem em VEIGA (1974) e ZOCKUN et alii (1976).

(3) A retórica de crescimento räpido encontrou seu auge no Governo de Juscelino Kubitschek retratada pelo slogam "cinquenta anos em cinco".

(4) O desempenho da produtividade dos fatores terra e mão-de-obra por Estados no Brasil é analisado em VERA FILHO e TOLLINI (1979). As qualificações modesta e insatisfatórios dependem dos objetivos em relação ao setor agricola. 
dos setores secundārio e terciärio três vezes maior a que prevalecia no setor primário. Notamos, assim, uma concentração setorial da renda. Para a concentração da renda colaborou a natureza capital in tensiva da industrialização de então, que exigia mão-de-obra com al to nível de qualificação e instrução, o que, ao mesmo tempo, permitia que a produtividade do trabalho crescesse no setor secundário. Como corolário, ainda, a natureza capital intensiva da substituição de importações absorveu pouca mão-de-obra liberada do setor agríco1a, gerando custos sociais.

Tão importante quanto estes desdobramentos no campo social, foram os efeitos no campo econômico, notadamente as repercussões em outros setores da economia. Neste aspecto, hā o reconhecimento, amplo entre os economistas, que a política de substituição de importações taxou o setor agrícola (SCHUH, 1968; zockun et alii, 1976; PASTORE, 1979 e LOPES e SCHUH, 1979).

O setor agropecuário, segundo essa linha de argumentação, teve contra si medidas discriminatôrias, tanto no campo interno como no campo das exportações. Quanto a este ūltimo, a persis tente sobrevalorização cambial (5), as restrições quantitativas atra vés de quotas, os impostos e as licenças funcionaram como mecanismos de restrição das exportações e o setor foi deixado à margem de

(5) KNIGHT (1971), BERGSMAN (1970) e LEMGRUBER (1976) quantificaram esta sobrevalorização. Os dois primeiros atravês da taxa de câm bio de equilíbrio e o ültimo pela taxa de câmbio de paridade. 
uma maíor participação nas vendas externas. Em contrapartida, quando surgiam crises de abastecimento, estas eram resolvidas com a importação de alimentos diretamente pelo governo ou com a concessão de crêdito para importação de gêneros alimentícios por firmas privadas. Ainda segundo esse argumento, a sobrevalorização cam bial, aliada a outros instrumentos como bonificações diferenciais e taxas de câmbio múltiplas, facilitou e beneficiou a importação de bens de capital e de matérias primas para as indústrias que se instalavam, ao mesmo tempo em que as exportações agrícolas eram taxadas. Estes e os demais instrumentos acima citados, implicitamentevi savam represar a oferta no mercado doméstico e, com isso, manter os preços internos dos alimentos em níveis baixos.

No campo interno, também se usou de uma gama de instrumentos que caracterizaram uma intervenção direta do governo na comercialização. Preço teto no varejo, controle de margens de comer cialização, política de estocagem e, algumas vezes, expropriação de estoques particulares são exemplos daquela intervenção. (б)

O resultado geral dessas medidas, de acordo com o ar gumentado, se ligava num aspecto mais amplo, que era uma política de alimento barato ("cheap food" policies), devido, basicamente, à importância dos alimentos como bens de salário para as indústrias que se iniciavam. PETERSON (1979) salienta que esta política envolveu um custo social que vários países, principalmente os menos desenvolvi-

(6) Para um comentārio dessas medidas, veja LOPES e SCHUH (1979). 
dos, tiveram que pagar. Estes. custos estão ligados a uma menor produ ção agrícola causada pelo achatamento dos preços recebidos pelos agricultores dos países menos desenvolvidos em relação aos preços re cebidos pelos produtores dos países mais desenvolvidos (7).

Naquela época, o principal instrumento utilizado para garantir uma tranquila evolução na produção, no abastecimento dos centros urbanos e nos preços dos alimentos, foi o desenvolvimento da infra-estrutura rodoviäria e, em menor escala, armazenamento, visan do facilitar a simples expansão da ärea cultivada. Somente na segun da metade dos anos sessenta é que começaram efetivamente outros ins trumentos de política agrîcola, que foram os preços mínimos e o cré dito $\operatorname{rural}(8)$.

A partir de 1964, o modelo de desenvolvimento foi mu dado para a ótica de promoção das exportações, calcada numa diversi ficação da pauta pelo incremento das exportações de manufaturados. Em 1968 fez-se modificação substancial na política cambial, através das miniảesvalorizações. Essa medida teve como finalidade principal estimular as vendas externas, uma vez que gerava menor risco de câm bio e estimulava contratos de longo prazo. Foi utilizada, também, a política fiscal como um fator de incentivo constante, em vista dos prêmios fiscais, isenções de impostos e incentivos creditícios, além de programas especiais de importação-exportação, conferidos sempre ao setor industrial.

(7) Suporta tambẻm a hipótese de que a eleaticidade no longo prazo da oferta agrícola é maior que um.

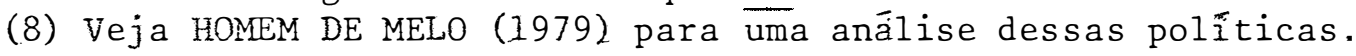


Do mesmo modo que no passado, os incentivos concedidos nesta fase de abertura externa foram direcionados para o setor secundārio, enquanto que o setor primário agrícola foi marginalizado. A exportação de produtos agrícolas "in natura" esteve sob controle de diversas medidas em que se destacavam as proibições de ven da ao exterior, os impostos na exportação e as quotas na comerciali zação externa. Adotou-se, nesse período, e mesmo no período anterior de substituições de importações, uma política de exportações agríco las baseada no conceito de excedente exportável ("exportable surplus") (LEFF, 1969). Dentro desse conceito, o País somente exportava um certo produto agrícola após o pleno abastecimento do mercado interno a um dado nível de preço.

As justificativas para esta orientação política que segregava o setor agrícola em relação ao tratamento preferencial da do ao setor industrial, mudaram ao longo dos anos após a II Guerra Mundial até os dias de hoje. Começaram pelas idéias de Prebisch,que se baseavam na necessidade de proteção temporária às indústrias manufatureiras, evitando competição com outros países. (argumento da indūstria infante, que dava ênfase aos aspectos dinâmicos da industrialização e à necessidade de proteção temporária para alguns setô res que se iniciavam) ${ }^{(9)}$ e no argumento de que as elasticidades pre

(9) BERGSMAN (1975) questionou a estrutura de proteção que prevaleceu até 1970. Existiam setores com taxas de proteção que não se justificavam: setores eficientes com proteção muito alta, uns poucos setores altamente protegidos inerentemente ineficientes e setores eficientes ou potencialmente eficientes, com proteção baixa ou mesmo negativa. Além disso, o aspecto de temporaridade, com exceção de um breve período na segunda metade da década de 60 (reduções tarifárias), foi 1 argamente negligenciado. 
ço da demanda de produtos agrícolas no mercado internacional deteriorariam os termos de troca e diminuiriam a receita cambial mais que proporcionalmente.

Do lado da oferta foi ressaltado que o nível de preço não afetaria a produção agrícola, o que vale dizer que a oferta seria insensîvel a mudanças nos preços.

Recentemente, existem argumentos para não promoção das exportações, por causa dos efeitos negativos que adviriam em termos de elevação do nível interno de preços ${ }^{(11)}$, abastecimento do mercado interno e diminuição do padrão nutricional, principalmente nas cạ madas de mais baixa renda. Em HOMEM DE MELO e ZOCKUN (1977), há uma análise desta questão em uma perspectiva de curto e de longo prazos. Ressaltam que o argumento contrário às exportações agrícolas esbarra em algumas incoerências na própria política governamental na ärea de abastecimento do mercado interno. Complementando, VEIGA (1979) as sinala que são necessários ajustes simultâneos na política de produ ção e abastecimento interno, assim como no setor agroindustrial e na política cambial e tributária, quando se toma uma medida de estí mulo às exportações.

(10) Citado por VEIGA (1979).

(11) HOMEM DE MELO (1981) salienta que durante $1967 / 79$ e para as di versas regiões brasileiras, os índices de preços de alimenta= ção aumentaram mais rapidamente que o índice geral de preços pa ra o Brasil e certos índices de preços ao consumidor. 
ZOCKUN et alii (1976) apontam as consequências dessas políticas de restrição às exportações agrícolas, salientando os seguintes pontos: a) diminuição da quantidade exportada e, portanto, redução na receita de divisas (dentro do conceito de pequeno País as demandas são perfeitamente elásticas, sendo este País apenas um tomador de preços); b) a renda do setor agrícola se reduz; c) crescimento do setor fica comprometido; e d) introduz-se um elemento adicional de incerteza e risco.

Além disso, a geração de divisas externas envolve cus tos domésticos. Há que se considerar, além dos benefícios brutos da geração de divisas, os efeitos alocativos de tais políticas. Qualificando este ponto, BARROS et alii (1975) dizem ser difícil justifi car, numa estratégia de abertura ao exterior, a manutenção de taxas sobre as exportações agrícolas que são, de fato, geradoras de divisas ao menor custo doméstico de recursos. Como um fator a mais, numa situação de balança comercial deficitária como foi a brasileira, mormente depois da crise do petröleo, o setor agrícola pode funcionar como uma fonte de divisas de respostas mais rápidas.

Entretanto, em termos políticos, a implementação de uma estratégia de incentivos às exportações agrïcolas esbarraria em dificuldades, pois ocorreria uma perda de arrecadação de impostos nos Estados exportadores, ao mesmo tempo em que se reduziria o grau de promoção efetiva nas exportações de produtos industriais que se utilizam predominantemente de produtos agrícolas em sua produção (PASTORE, 1979). 
Uma outra faceta do argumento da discriminação é encontrada no setor fornecedor de insumos modernos para a agricultura. A crescente importância desses insumos nos custos de produção das di versas culturas qualifica o poder desses componentes em carregar ta xações indiretas para todo o processo de produção agropecuária. As diversas medidas tomadas em favor da produção interna ou importação desses insumos refletiram em preços maiores ou menores pagos pelos agricultores. Atê a primeira metade dos anos sessenta, os insumos agrícolas (máquinas, fertilizantes e defensivos) tiveram subsídios implícitos em suas importações (12) e isto seria um contrapeso para as medidas que discriminaram contra a agricultura. Dizia-se que a concessão desses subsídios amenizaria as reações contrárias ao esti 1o de desenvolvimento econômico seguido até então. (13)

Na primeira metade dos anos sessenta houve a intenção do governo de incentivar a produção doméstica desses insumos através de um processo de substituição de importação, que encontrou sua expressão maior no setor de fertilizantes. A introdução de tari fas aduaneiras na importação de alguns nutrientes e o contigenciamento (14) foram exemplos de medidas beneficiando a produção interna de adubos. Para o setor de máquinas houve a suspensão do privilégio

(12) HOMEM DE MELO (1979) quantifica as taxas implícitas na importa ção desses insumos. Apesar de positivas durante o período 195 $/$ 66, é nîtida a tendência decrescente que se inicia no começo dos anos sessenta, sendo que a maioria daquelas taxas estiveram próximas de zero no período 1962/66.

(13) Argumento de BERGSMAM e CANDAU (1969).

(14) ZOCKUN et alii (1976). 
cambial na importação de tratores e, inclusive, proteção tarifäria para a produção doméstica (15). Estas medidas trouxeram como efeito uma proteção para as indūstrias produtoras desses insumos e uma taxa ção para os produtores agrícolas na forma de preços pagos mais elevados em relação aos prevalecentes no mercado internacional.

Existem alguns trabalhos que procuram medir empirica mente estas taxações via preço, tanto na forma agregada (BERGSMAN, 1975), como para cada produto individualmente (VEIGA, 1974 e HOMEM DE MELO, 1981) .

Para os objetivos desta pesquisa é oportuno um detaThamento dos argumentos e das conclusões obtidas por HOMEM DE MELO (1980), mesmo porque questiona muitos dos pontos acima citados. Argumenta o autor que muitas das críticas em cima da sobrevalorização cambial e sobre o processo de substituição de importações estão cal cadas numa visão estática do problema. Segundo ele,"identificar a so brevalorização da taxa de câmbio como uma distorção ignora a possibilidade de que a proteção tarifäria (da mesma forma que subsídios à produção) tenha sido introduzida para corrigir divergências (16) do mésticas, como, por exemplo, no caso de economias dinâmicas internas e externas. Em outras palavras, o objetivo da proteção seria rea lizar uma transformação estrutural no sentido de tornar a economia mais industrializada, em relação ao período anterior". Ainda de acor

(15) HOMEM DE MELO (1979).

(16) Divergência é uma discrepância entre custos e benefícios priva dos e sociais, quaisquer que tenham sido suas causas. Distor= ção é uma divergência causada pela política governamental. Veja CORDEM (1974). 
do com o autor, "o ponto básico é que uma dada proteção, na forma de tarifas sobre as importações, subsídios à produção ou outras alternativas, não é suficiente para caracterizar a taxa de câmbio sobrevalorizada como uma distorção. Para isso, seria preciso demonstrar que a proteção não era justificada em termos econômicos". Este estudo pretendeu, ainda, qualificar as opiniões unânimes sobre a dis criminação da agricultura, principalmente aquelas identificadas com as políticas de alimento barato, nas quais estava implícito a neces sidade de correção dos preços agrícolas, como pré-condição para o crescimento adequado do setor primário.

Esse autor estudou a relação preço interno/preço no mercado internacional para os produtos agrícolas numa série históri ca, compreendendo o período 1948/77. Ressaltou, entretanto, que, ao contrário do que estava subentendido no pensamento daqueles autores, o-setor agrícola era dividido entre um subsetor doméstico (fechado às variáveis do mercado internacional) e um subsetor exportador, em que as variāveis externas influenciavam no mercado; esta divisão po deria mudar parte das conclusões sobre discriminação da agricultura. Posto isto, os resultados mostraram que os produtos do ramo doméstico apresentaram relações preço interno/preço interna cional superiores a um na grande maioria dos anos, enquanto os produtos de exportação apresentaram aquela relação em sua maioria meno res que a unidade. Como conclusão, quem na verdade estava sendo taxado era o consumidor, haja vista a importância nutricional e orça- 
mentária dos produtos do subsetor doméstico, principalmente para as famỉlias de menores rendas.

Pode-se questionar que a taxação foi analisada tão somente em termos nominais (preço do produto). Um conceito mais amplo de proteção/taxação é obtido quando todo processo produtivo é considerado, incorporando tanto as taxações impostas no produto final (nominal) quanto nos insumos necessários à produção (efetiva) (17). Do que foi abordado nos parägrafos anteriores, emergem os seguintes pontos principais. Primeiro: existe um consenso en tre vários trabalhos, de que a agricultura brasileira sofreu um pro cesso de discriminação, quando a ênfase do desenvolvimento se voltou para a industrialização. Segundo: essa discriminação ou taxação foi implementada tanto a nível de preço de produto como a nível de preço de insumo. Terceiro: a anảlise da taxação do setor agrícola, em uma forma desagregada (por produto) e em relação aos preços recebidos pelos produtores, mostrou que, ao conträrio do que se supunha, parte da agricultura foi beneficiada. Por último, não existem estudos que procurassem analisar conjuntamente estes dois níveis de taxação (preço de insumos e preço de produtos) principalmente em períodos recentes quando passou-se a incentivar internamente a produção de um nümero crescente de insumos agrícolas.

(17) VALDEZ (1973) analisou, para a agropecuảria chilena, a taxação em termos efetivos no período 1947/65. As taxas foram negativas tanto para os produtos de exportação como de importação. Quantifica, tambẻm, o efeito negativo dessas taxações na produ ção e na balança comercial dos produtos agrícolas. 


\section{2 - Tecnologia e Discriminação}

Da seção anterior pode-se inferir que as políticas voltadas para o setor agropecuário se preocuparam, num primeiro período, com os problemas estruturais da comercialização (principalmente estradas e armazéns). Posteriormente, essas políticas se deslocaram para mecanismos de incentivos de curto prazo, destacando o crédito rural subsidiado e os preços mínimos de garantia. De um modo geral, o problema da produtividade dos fatores do setor não foi questionado pelos formulistas de política, sendo que os esforços es tiveram concentrados no crescimento extensivo pela ocupação de fron teiras.

Nesse aspecto, a preocupação com os niveis tecnológi cos de nossa agricultura apareceu apenas em períodos recentes, quan do as exigências sobre o setor agrícola aumentaram ${ }^{(18)}$. Desde a II Guerra Mundial apenas esforços localizados de geração de tecnologia agrícola podem ser destacados como contribuidores para o crescimento da oferta interna.

Nesta seção não se pretende fazer uma avaliação histōrica do problema tecnológico dos diversos produtos, mas, sim, explicitar o argumento da tecnologia como um fator importante na anālise da discriminação do setor. A despreocupação ou a pouca ênfase (18) Em princípio, a produção de alimentos para o mercado interno e as vendas ao exterior são as maiores pressões sobre o setor. Após 1973, en virtude dos desequilíbrios externos, as exigências sobre a agricultura de exportação foram aumentadas. Ademais, após a implantação de programas especiais de produção de energia através de fontes renovāveis (PROALCOOL), à agricultura coube o papel de supridora de combustiveis. 
dada na geração de tecnologia agrícola pode ter sido um elemento adicional importante na taxação da agricultura ${ }^{(19)}$.

Antes de entrar no argumento tecnológico, se discorrerä sobre a segmentação do setor agrícola brasileiro. Não se questionará este aspecto, visto que existem estudos comprobatórios a respeito $(20)$.

Esta subdivisão se mostra pela presença de um subsetor doméstico, por um subsetor exportador que inclui os produtos nor malmente presentes na pauta de exportação, e por um subsetor intermediārio que se comporta alternativamente como doméstico ou de exportação. No primeiro grupo estão os produtos arroz, batata, cebola, feijão e mandioca. No grupo de exportação estão algodão, café, cana-de-açūcar e soja, e no grupo intermediário milho e amendoim.

A distinção entre os dois primeiros grupos é feitana hipötese de que, para o primeiro (produtos domésticos), os preços e as decisões de plantio dependem apenas das variäveis do mercado interno, e da política do governo. No grupo de exportáveis, admite-se que o mercado internacional determina, de forma importante, a alocação e crescimento da produção. No subsetor de produtos domésticos temos um mercado funcionando como uma economia fechada, ou seja, apenas demanda e oferta internas determinam preço e quantidade. Por sua vez, o subsetor de exportação funciona em uma situação de econo mia aberta, estando a produção sujeita aos níveis de preços prevale centes no mercado internacional, aos valores da taxa de câmbio e à

(19) SILVA, FONSECA e MARTIM (1980a) ressaltam, tanto para o Brasil, como, principalmente, para São Paulo, uma aparente distorção na alocação de recursos às atividades de geraçäo e difusão de tecnologia.

(20) HOMEM DE MELO (1978). 
política comercial.

$\mathrm{Na}$ distinção entre estes subsetores, há correspondên cia entre os mecanismos formadores de preço e o destino da produção. As culturas do subsetor exportador estão presentes nas listas de ex portação de produtos agrícolas, enquanto as culturas do subsetor do méstico se destinam basicamente ao consumo interno. Milho e amendoim como culturas intermediārias, são, em alguns anos, exportadas.

Alêm dessa hipótese bāsica de diferenciação entre se tores, outro aspecto contribui para esta segmentação. Nesse particu lar, a geração de tecnologia ou os recursos aplicados em pesquisa agrícola têm se voltado em maior intensidade para o grupo de exportáveis. Há evidências para o caso do Estado de São Paulo, mostrando que o maior esforço de pesquisa nos últịmos anos se dirigiu para pro dutos de exportação e somente em períodos recentes ele vem se deslo cando para produtos domésticos. PASTORE, DIAS e CASTRO (1976), explicando as condiçøes responsáveis pelos movimentos de criação e di fusão de tecnologia, assinalam que no subsetor doméstico,pelas suas características de dispersão geogräfica, culturas de fronteira e im possibilidade de internalização dos ganhos, os mecanismos de mercado são insuficientes para induzir uma modernização do setor.

Este fator tecnológico, aliado à oportunidade de se expor às forças do mercado internacional, tem aumentado a rentabili dade do grupo de exportáveis em detrimento do grupo voltado para o setor doméstico. As inovações tecnológicas têm a capacidade de redu zir os custos de produção e aumentar a lucratividade da atividade beneficiada. 
Resumindo, as distinções entre um ramo doméstico e um ramo exportador são feitas baseadas na origem das forças de mercado, no estado tecnológico e na lucratividade de cada subsetor.

A ligaçãc que se faz entre estas disparidades tecnológicas e a discriminação teve como primeiro argumentador SCHUH $(1974)^{(21)}$. Quando um estoque de nova tecnologia de produção está disponível para o setor agrícola, as políticas de preço que discriminam contra a agricultura podem, na realidade, acelerar a taxa de mudança tecnológica e, com isso, compensar a queda da lucratividade com aumento da produtividade.

Numa situação onde novas técnicas de produção não es tejam disponíveis, entretanto, as políticas de preços dos produtos podem causar sérias consequências na produção, atē mesmo podendo fa zer um País passar da posição de exportador líquido de produtos agrícolas para a posição de importador.

Assim, os diversos instrumentos de política comercial discutidos anteriormente, e que foram contra a agricultura, poderiam ter seus efeitos compensados por uma maior geração e adoção de inovações tecnológicas. A geração de tecnologia seria uma forma de compensar a agricultura as taxaçöes impostas pelas políticas comerciais determinando um papel crucial no impacto e efeitos dessas politicas.

(21). Citado por LOPES e SCHUH (1979), em que o raciocínio do texto se baseia. 


\section{3 - objetivos}

Dentro do que foi abordado nos ittens anteriores, säo dois os objetivos desta pesquisa:

a) Analisar os argumentos de taxação/proteção do setor agrícola em termos efetivos, concentrando esta análise em períodos recentes quando houve a intenção de produzir internamente muitos insumos agrícolas, antes importados.

b) O segundo objetivo é qualificar as disparidades tecnológicas entre os diversos produtos da agricultura como um elemento amenizador das diversas políticas seguidas. Nesta parte da pesquisa se farā uma revisão dos diversos estudos que mediram essas disparidades tecnológicas e se tentarā avaliar como elas se encaixam no argu mento acima referido. Não se pretende uma pesquisa pioneira na ārea da modernização da agricultura, senão, apenas, utilizar os trabalhos já realizados para questionar de uma maneira mais abrangente o argu mento da discriminação contra a agricultura. 


\section{1 - Conceitos Básicos}

No desenvolvimento inicial da teoria sobre o comërcio internacional, os estudiosos se limitavam a tratar as transações apenas em termos de produto final, e supunha-se, implicitamente, que os insumos, ou eram originados no próprio País, ou obtidos sob condições de comércio livre. Dentro deste raciocínio surgiu o conceito de Proteção Nominal (PN), que é definida como a porcentagem que o preço interno excede o preço no mercado internacional, sen do este transformado pela taxa de câmbio de mercado. A Taxa de Proteção Nominal, assim obtida, é uma medida grosseira do resultado de efeitos combinados de políticas que afetam o preço interno, direta ou indiretamente, em relação ao preço mundial. 
Mais recentemente surgiu um novo conceito através da teoria da Proteção Efetiva, desenvolvida principalmente por Balassa, Cordem e Johnson. A Taxa de Proteção Efetiva (TPE) expressa a margem de proteção em termos de porcentagem do excesso do valor adi cionado internamente em relação ao valor adicionado no mercado internacional, sendo este excesso o resultado de tarifas e outras medidas protecionistas nos insumos e nos produtos. Nesta idéia a abor dagem é mais ampla, porquanto considera todo o processo produtivo e não apenas o produto final. A proteção efetiva para um produto não é influenciada por tarifas sobre insumos dos insumos. É preciso des cer apenas um degrau na estrutura de insumo-produto. (22)

Dizemos que uma atividade estā protegida quando sua Taxa de Proteção Efetiva é positiva e, de maneira contrāria, dizemos que está sendo taxada quando aquela taxa é negativa. Uma Taxa de Proteção Efetiva de $20 \%$ para uma determinada atividade nos diz que o preço efetivo ${ }^{(23)}$ está recebendo uma proteção de $20 \%$ em relação àquele prevalecente no mercado internacional. Convém lembrar que essa taxa pode não ser suficiente para a rentabilidade da atividade (BAUM, 1977).

Admitamos uma indūstria de exportação de carne ${ }^{(24)}$. Esta atividade deve vender aos preços do mercado internacional, mas

(22) Ver CORDEM, W.M., 1979, p. 197.

(23) Ver o Ítem 1.2: Formulação Algébrica.

(24) Exemplo usado por BALASSA. (1971). 
păga seus insumos, como a ração, aos preços internos acrescidos de um imposto. Se a ração e outros insumos correspondem a $60 \%$ do preço da carne, e são submetidos a um tributo de 10\%, a proteção efetiva para a carne será negativa. Isto é, o sistema protetor aplicado cas tiga a produção de carne. Se tomarmos o preço da carne de 100 cruzeiros, no mercado mundial, o aumento induzido pelo imposto no preço interno dos insumos (de 60 para 66 cruzeiros) ocasiona uma diminuição no valor agregado de 40 para 34 cruzeiros. Desse modo o TPE é igual a $-15 \%$.

No cálculo da TPE, portanto, entra um componente nominal ditado pelas tarifas do produto e um componente efetivo que engloba as tarifas nos insumos considerados.

Um conceito mais completo que o de Proteção Efetiva e a Proteção Efetiva "Líquida" ou Proteção Efetiva Compensada, que é obtido quando os.valores da sobrevalorização cambial também são considerados.

Nos setores de substituição de importações, onde a TPE é normalmente positiva, a fórmula convencional não compensada superestima o grau de proteção efetiva, já que ignora o fato da sobrevalorização cambial neutralizar parte da proteção tarifária concedida. Nos setores de exportação, onde, na ausência de subsídios, a proteção efetiva é nula ou negativa, a sobrevalorização cambial atua como uma taxação adicional às exportações (NEUHAUS, 1977).

A Tarifa de Proteção Efetiva Líquida (ou Compensada) 
é obtida quando a taxa de câmbio usada é aquela referente à situação hipotética de livre comércio. Para tanto, se calcula uma taxa de câmbio de equilíbrio. (25)

As diversas atividades podem ser ordenadas segundo uma escala de proteção. Assim, uma colocação em ordem de grandeza das atividades possibilita visualizar a estrutura de proteção dentro da economia. Uma das utilidades da TPE é verificar o efeito des sa estrutura de proteção sobre o remanejamento de recursos entre as atividades. Pode-se dizer, como primeira aproximação, que os recursos serão deslocados das atividades menos protegidas para as mais protegidas, isto $\bar{e}$, das atividades com menores TPE para as com maio res TPE.

Por fim, deve-se atentar para as pressuposições que estão por detrás do cálculo do TPE. Supõe-se que: a) a produção se dá em condições de rendimento constante à escala; b) existe competi ção perfeita; c) a elasticidade de oferta de importações e a elasti cidade de demanda de exportação são infinitas (conceitos de país pe queno); e d) os custos de transportes não são considerados. $\bar{A}$ exceção da ūltima pressuposição, pode-se afirmar que a agricultura, pelas suas características, não contraria as demais. Quanto ao setor de insumos, na condição de setor industrial as suposições acima são certamente fortes.

(25) Em BALASSA (1971), Apêndice A, há o detalhamento da metodologia para o cálculo da taxa de câmbio de equilíbrio. Ela é definida como a taxa que manteria a balança comercial inalterada, na ausência de proteção, de taxas de exportação ou subsídios. 
3.2 - Formulação Algēbrica (26)

Mostra-se, a seguirir, como pode ser obtida a Taxa de Proteção Efetiva (TPE), para uma atividade produzindo o produto $\underline{j}$ e utilizando o insumo $\underline{i}$.

Sejam:

$\mathrm{P}_{\mathrm{v}}=$ valor adicionado por unidade do produto $j$ sem a imposição de tarifas;

$\mathrm{P}_{\mathrm{V}}^{\prime}=$ valor adicionado por unidade $j$ com proteção tarifária.

$G_{j}=$ taxa de proteção efetiva para o produto $j$;

$\mathrm{P}_{\mathrm{j}}=$ preço nominal de uma unidade de $\mathrm{j}$ em livre comércio;

$A_{i j}=$ participação porcentual do insumo $i$ no custo de uma unida de de $j$ em livre comércio;

$A_{i j}^{\prime}=$ participação porcentual do insumo $i$ no custo de uma unida de de $j$ após a tarifa;

$t_{i}=$ taxa de tarifa sobre $i$;

$t_{j}=$ taxa de tarifa sobre $j$.

Então:

$$
\begin{aligned}
& P_{v}=P_{j}\left(1-A_{i j}\right) \\
& P_{v}^{\prime}=P_{j}\left[\left(1+t_{j}\right)-A_{i j}\left(1+t_{i}\right)\right] \\
& G_{j}=\frac{P_{v}^{\prime}-P_{v}}{P_{v}}
\end{aligned}
$$

(26) Baseada em CORDEM (1971). 
26.

Substituindo (1) e (2) em (3) tem-se:

$$
G_{j}=\frac{t_{j}-A_{i j} t_{i}}{1-A_{i j}}
$$

Esta é a fórmula chave e suas implicações podem ser extraídas como segue:

$$
\text { Se } t_{j}=t_{i} \text {, então } G_{j}=t_{j}=t_{i}
$$

A taxa de proteção efetiva será igual às tarifas sobre $i$ e j quando a tarifa no produto é igual a do insumo.

$$
\begin{aligned}
& \text { Se } t_{j}<t_{i} \text {, então } G_{j}<t_{j}<t_{i} \\
& \text { Se } t_{j}>t_{i}, \text { então } G_{j}>t_{j}>t_{i} \\
& \text { se } t_{j}<A_{i j} . t_{i} \text {, então } G_{j}<0 .
\end{aligned}
$$

Esta ültima é a condição para uma taxa de proteção efetiva negativa. Ela será negativa ainda que as tarifas sobre i e J sejam positivas.

$$
\text { Se } t_{j}=0 \text {, então } G_{j}=-\frac{t_{j} A_{i j}}{1-A_{i j}} \text {. }
$$

Se existe tarifa apenas sobre os insumos, a TPE será negativa.

$$
\text { Se } t_{i}=0 \text {, entäo } G_{j}=\frac{t_{j}}{1-A_{i j}} \text {. }
$$


Não haveñdo tarifa sobre insumos, a TPE serä maior que a tarifa sobre produtos.

$$
\frac{\partial G_{j}}{\partial t_{j}}=\frac{1}{1-A_{i j}}
$$

(VIII)

$$
\frac{\partial G_{j}}{\partial t_{i}}=\frac{A_{i j}}{1-A_{i j}}
$$

Em (VII) e (VIII) tem-se a variação da taxa de prote ção efetiva em resposta às variações na tarifa sobre o produto e so bre o insumo, respectivamente.

Para o cálculo de $A_{i j}^{\prime}$, a participação do insumo i no custo de uma unidade de j após a oferta, tem-se a fórmula (5)

$$
A_{i j}^{\prime}=A_{i j} \frac{1+t_{i}}{1+t_{j}}
$$

Substituindo (5) em (4) tem-se:

$$
G_{j}=\frac{\frac{t_{j}}{1+t_{j}}-\frac{A_{i j}^{\prime} t_{i}}{1+t_{i}}}{-\frac{1}{1+t_{j}}-\frac{A_{i j}^{\prime}}{1+t_{i}}}
$$

Em (6) tem-se a fórmula da TPE reescrita em termos da participação dos insumos após a tarifa. A equação (6) é a normalmen te usada em estudos empíricos, quando os dados são derivados do país que tem as tarifas. 
A equação chave (4), que era formulada para um insumo, pode ser estendida para um nümero $\underline{\mathrm{n}}$ de insumos

$$
G_{j}=\frac{t_{j}-\sum_{i}^{n} A_{i j} t_{i}}{1-\sum_{i}^{n} A_{i j}}
$$

$\operatorname{com} i=1,2, \ldots, n$.

As implicações são as mesmas que para a fórmula (4), exceto que em lugar de uma única tarifa no insumo, $t_{\dot{i}}$, é necessārio calcular a média ponderada das tarifas de insumos.

\section{3 - Método de Cálculo}

A finalidade desta seção é detalhar os passos empíri cos seguidos no cálculo da tarifa de proteção efetiva para uma atividade $j\left(G_{j}\right)$. Todas as definições a seguir são relativas a um produto obtido de uma determinada atividade $j$. Como citado na formulação algébrica, temos a equação (3).

$$
G_{j}=\frac{P_{v}^{\prime}-P_{v}}{P_{v}} .
$$

Para o cálculo de $\mathrm{P}_{\mathrm{v}}$ e $\mathrm{P}_{\mathrm{V}}^{\prime}$ tem-se:

$$
P_{V}=P M I-C L C,
$$

onde: 
29.

PMI = preço do produto no mercado internacional;

CLC = custo de uma unidade do produto $j$ em Iivre comércio;

$$
\mathrm{CLC}=\sum_{i=1}^{\mathrm{m}} \mathrm{CT}_{i} \mathrm{P}_{i},
$$

com,

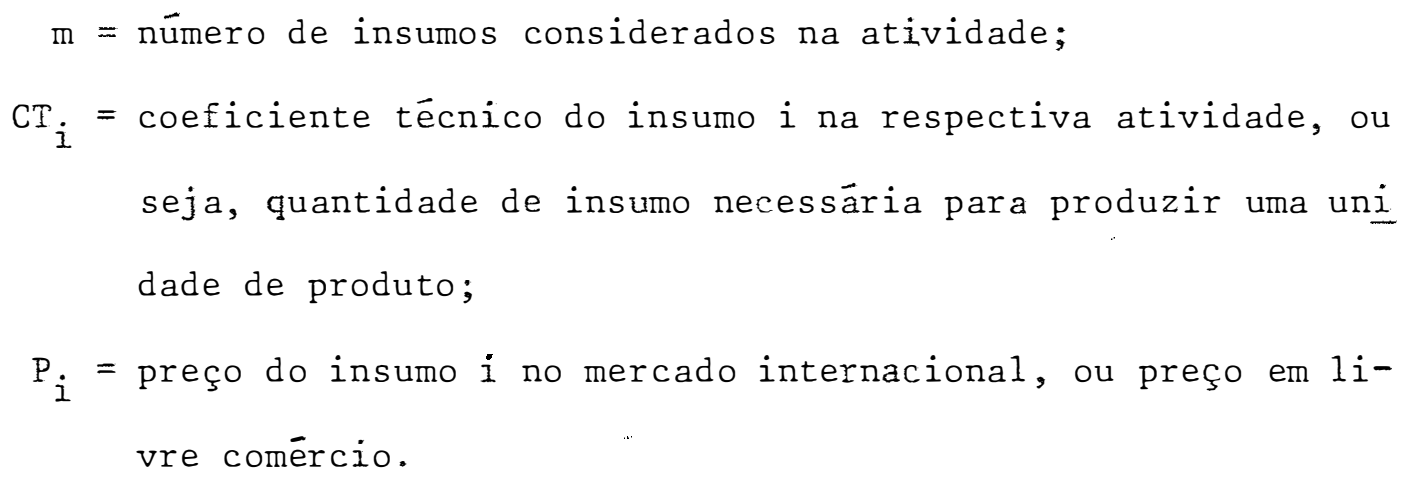
seja, quantidade de insumo necessäria para produzir uma uni dade de produto;

$\mathrm{P}_{i}=$ preço do insumo $i$ no mercado internacional, ou preço em 1ivre comércio.

$$
P_{v}^{\prime}=P I-C P
$$

onde:

$$
\begin{aligned}
& \mathrm{PI}=\text { preço do produto no mercado interno; } \\
& \mathrm{CP}=\text { custo de uma unidade do produto } j \text { com protecionismo; } \\
& \qquad \mathrm{CP}=\sum_{i=1}^{\mathrm{m}} \mathrm{CT} i \mathrm{PP} \\
& \mathrm{PP}_{i}=\text { preço do insumo } i \text { no mercado interno ou preço do insumo com } \\
& \text { protecionismo. }
\end{aligned}
$$

com, 


$$
\begin{gathered}
\text { Substituindo (9) em (8) e (11) em (10) tem-se: } \\
P_{v}=P M I-\sum_{i=1}^{m} C T_{i} \cdot P_{i} \\
P_{v}^{r}=P I-\sum_{i=1}^{m} C T_{i} \cdot P_{i} \\
\text { Levando }(12) e(13) \text { em }(3) o b t e m_{-s e} \\
G_{j}=\frac{\left.\sum_{i=1} C T_{i} \cdot P P_{i}\right)-\left(P M I-\sum_{i=1} C T_{i} \cdot P_{i}\right)}{\left(P M I-\sum_{i=1}^{m} C T_{i} \cdot P_{i}\right)}
\end{gathered}
$$

A fórmula (14) foi usada para o cálculo da TPE (G $\left.{ }_{j}\right)$ para cada atividade.

Para o cômputo da proteção nominal, ou seja, a prote çao implícita apenas no preço do produto ou o excesso do percentual do preço interno em relação ao preço no mercado internacional, tem-se:

$$
T_{j}=\frac{P I-P M I}{P M I},
$$

com $\mathrm{T}_{j}=$ taxa de proteção nominal para o produto da atividade $j$. 


\section{A - Insumos Não Comercializāveis ("Non-Tradables")}

Na composição do valor agregado de um bem existè a participação de insumos normalmente transacionados internacionalmen te, assim como de insumos cujo consumo é atendido somente pela produção doméstica, sendo que seus preços não são cotados no mercado ex terno.

o transporte interno e os serviços em geral são exem plos desse tipo de insumos não comercializados entre países. Para o setor agrícola, alēm dos transportes, os serviços de irrigação e energia elétrica são exemplos de não transacionados e que contribuem significativamente para composição do valor agregado de muitas atividades.

Como salienta BAUM (1977), é difícil, às vezes, esta belecer uma linha divisória entre comercializáveis e não comerciali záveis. Estes ūltimos podem ter um substituto prōximo que é comercializável, e cujo preço termina influenciando o insumo não comercializado.

o fato é que a teoria exposta nos îtens anteriores não incluiu estes insumos e as tarifas que incidem sobre eles. As considerações que se seguem tentam qualificar esta exclusão.

No tratamento que se dá a esses insumos no cálculo da taxa de proteção efetiva têm-se duas abordagens alternativas.

A primeira abordagem surgida foi posta por Balassa. 
Procura restringir o conceito de proteção efetiva à atividade em questão, ao invés de estendê-lo aos não comercializáveis. Trata o insumo "non-tradable" como qualquer outro" "tradable", porém com uma tarifa zero. Estes insumos não são incluídos no denominador da equa ção (7) $\left(1-\sum_{i} A_{i j}\right)^{(27)}$.

Uma abordagem alternativa foi sugerida posteriormente por Cordem, e consiste em incluir o valor agregado na produção de insumos não comercializados com o valor agregado durante o processo de transformação na atividade de que se trata, de modo que o grau de proteção se calcula com respeito à soma dos dois. A proteção para uma atividade produzindo um bem comercializado representa não apenas proteção para os fatores primários intensivos nessa atividade, mas, tambēm, proteção para as indústrias que fazem insumos não comercializados, nos quais tal atividade é intensiva e, assim, indire tamente proteção para os fatores primários nestas indústrias de insumos não comercializados.

\section{5 - Considerações Sobre a Implementação da Anālise}

A implementação da anālise proposta nas consideraçöes teōricas feitas anteriormente esbarrou em inúmeras dificuldades ligadas, principalmente, à disponibilidade estatística e às caracte-

(27) O método de Balassa superestima a proteção efetiva. Veja nota de rodapé (24), NEUHAUS (1977).

(28) Para um exemplo analítico sobre os dois métodos, olhar CORDEM (1979). BALASSA (1971) dá o tratamento matemático das duas abor dagens. 
rísticas particulares do setor agrícola.

A inexistência de dados foi o primeiro entrave para que se tivesse uma pesquisa mais abrangente. A disponibilidade de dados não permitiu que a teoria proposta fosse implementada em sua totalidade, além do que vários ajustes tiveram que ser feitos.

o conceito de proteção efetiva, por levar em conside ração todo o processo produtivo, exige um estudo do setor fornecedor dos insumos que participam desse processo produtivo. Um ponto importante é detectar esses insumos, levando em conta suas participações no custo de produção de cada atividade e a possibilidade de serem comercializados entre países (insumos "tradables") (29).

Levando estes pontos em consideração, nota-se que pa ra o caso do setor agrícola, o tripé de insumos modernos, fertilizantes, defensivos e mäquinas preenche os requisitos. São transacionados normalmente entre países e suas participações nos custos agrî́colas podem atingir até $60 \%$. (30) Nesse tripé pode estar uma fonte de taxação até agora não quantificada nos estudos sobre discriminação da agricultura. A idéia básica é detectar"esta parte da taxação ligada de maneira mais ampla ao processo de desenvolvimento econômico do Brasil.

A falta de dados não permitiu que se considerassem to dos os insumos modernos, sendo que as maiores dificuldades foram en

(29) Os insumos não comercializáveis (serviços, trabalho, terra, entre outros) receberam considerações teóricas de vários economistas. Ver CORDEM (1971) e CORDEM (1979).

(30) Olhar Seção 5, Resultados e Discussão. 
contradas no setor de defensivos. Este setor caracteriza-se por gran de número de produtos e de marcas comerciais, agrupados principalmente nas classes dos herbicidas, fungicidas e inseticidas. Eum se tor com intensa atividade de pesquisa e novos produtos são lançados no mercado em pequenos espaços de tempo, enquanto outros são retira dos. Hâ dificuldade de correspondência de dados de produtos e marcas comerciais entre o mercado interno e o mercado de outros países. Tentou-se fazer a análise em termos de preço no Brasil e preço nos Estados Unidos, em vista da grande dependência das importações brasileiras para com este país: (Tabela 37), mas os fatores acima apontados não a possibilitaram. Os coeficientes técnicos não detalham o bastante para inclusão dos únicos produtos que apresentaram correspondência (Brometo de metila e sulfato de cobre). Mesmo que istofós se possïvel, poderia se questionar a representatividade desses dois produtos.

Quanto às mäquinas, as comparações de preços internos e preços externos não foram possĩveis porque não se conseguiu nenhum dos dois preços em sintonia com as marcas comerciais. Alêm disso, o diferencial de qualidade entre nossas máquinas e as importadas exigia difíceis ajustes. Não obstante, conforme dados da Tabe la 12, a análise dos custos diärios de tratores indica as participa ções majoritārias e crescentes de combustíveis e lubrificantes, enquanto a depreciação,que engloba o preço de compra em seus cálculos, era minoritäria (31) . Os derivados do petróleo, então, têm mais chan (31) Deve-se ressaltar que a análise de custo de máquinas do IEA não incluiram os custos do capital, representado pela remuneração do investimento efetuado na compra dessas mäquinas. Os critërios do IEA para o cálculo da depreciação estão no rodapé da Tabela 13. 
ces de carregar subsídios ou taxações para o setor. Os cálculos foram feitos levando estes produtos em conta.

Fertilizantes, por terem um mercado internacional de finido, e por seus produtos poderem ser analisados em termos dos principais macronutrientes ( $N, P$ e $K$ ), não apresentaram dificuldades.

Os coeficientes técricos (quantidade de insumos necessária para produzir uma unidade do produto), foram obtidos através dos dados de custo de produção do Instituto de Economia Agrícola (IEA) (32). Ao analisar estes coeficientes, deve-se lembrar que a agricultura se caracteriza pela grande dependência das condições climáticas, sendo que suas atividades se desenvolvem em situações pouco controladas. Além disso, a grande dispersão geográfica torna ainda mais variāvel a influência dessas condições climáticas. Os coe ficientes técnicos, portanto, além das influências dos parâmetros econômicos (preço relativo, volume de crédito, entre outros) e de parâmetros de médio e longo prazo como as mudanças tecnológicas,são afetados por fatores aleatörios, como as condições do clima e efeitos regionais. Os coeficientes técnicos estimados pelo IEA não captam a maioria dessas mudanças. Como se detalhará adiante, levou-se em conta algumas diferenças regionais para a composição de um coefi ciente agregado para o Estado de São Paulo.

(32) Informações Econômicas. 
4. DESCRIÇAOO DOS DADOS UTILIZADOS

\section{1 - Periodo, Produtos e Região Anatisados}

Este estudo engloba o período de dez anos, compreendidos entre 1968 e 1978. Nos objetivos iniciais deste trabalho esta va a intenção de analisar um período recente em razão da carência de pesquisas e da relevância das mudanças econômicas que se processaram nos últimos quinze anos. A partir de 1964 o Paî́s experimentou muitas mudanģas nas políticas econômicas e nos instrumentos de polí tica agrícola. A questão da discriminação ou taxação da agricultura numa época de alto crescimento industrial e econômico foi o pon-, to central deste estudo.

Alēm destas razões de cunho econômico, as próprias disponibilidades estatísticas não permittiram que se regredisse aquém deste período. 
Foram incluidos cinco produtos na pesquisa: arroz, feijão, milho, algodão e soja. Dois deles tidos como de mercado interno (arroz e feijão), dois do subsetor exportador (soja e algodão) e um intermediārio (milho) (33). A obtenção dos coeficientes fí sicos de produção para estes produtos não apresenta os inconvenientes que se encontram nas culturas perenes como café e frutíferas, e nos produtos pecuários (leite e carne). A cana-de-açücar não foi es tudada por ser o açūcar o produto final com transação no mercado in ternacional. Os coeficientes físicos da cultura da cana teriam que ser transformados para açücar, com problemas de ajustamento, uma vez que a parte industrial de produção teria que ser considerada.

Arroz e feijão se revelam pela grande importância nu tricional, notadamente para as famílias de baixa renda (34). Soja, juntamente com seus derivados, tem sido um dos principais ítens da pauta de exportação brasileira. Milho e algodão, além do potencial exportador, têm expressiva importância como matéria prima industrial. A adição de outros produtos (cebola, batata, amendoim, trigo) seria um passo seguinte a ser dado nesta pesquisa.

O estudo de várias regiões do Brasil, em vista das marcantes diferenças regionais (nível de tecnologia, preços pagos e recebidos, produtos) $\bar{e}$ impossibilitado pela insuficiência dos dados. Apenas para o Estado de São Paulo há dados em séries históricas e

(33) Para detalhes da subdivisão em setor interno e externo, ver se ção 2.2.

(34) ALVES e VIEIRA (1978) mostraram que arroz e feijão eram,em 1971, responsáveis por $35 \%$ das calorias e $39 \%$ das proteínas que as fa. mílias de baixa renda consumiam. 
detalhados o suficiente para a realização desta pesquisa.

\section{2 - Preços}

\subsection{1 - Preços de produtos}

Tanto para produtos como para insumos, os dados de preços internacionais foram tomados como cotações que prevaleceriam no caso de haver livre comércio. Em outras palavras, o Brasil foi tomado como um país pequeno, tanto na compra de insumos como na venda de produtos. No caso dos produtos de exportação (soja e algodão), pode-se afirmar que o Brasil não possuiu uma participação em condições de influir nas cotações do mercado internacional, funcionando, assim, como um tomador de preços nos anos considerados. A soja brasileira cresceu muito de importância no comércio exterior, mas suas exportações totais recentes estão na faixa de $5 \%$ do total mundial.

Posto isto, o passo seguinte foi encontrar preços nos mercados interno e externo que fossem representativos e comparáveis entre si. Para preços no mercado interno, adotaram-se os preços recebidos pelos produtores do Estado de São Paulo, publicados pelo In $\underline{\underline{s}}$ tituto de Economia Agrícola. Para cotações internacionais usaram-se os preços anuais médios de exportação editados pela FAO ${ }^{(35)}$.

(35) HOMEM DE MELO (1981) adotou estes preços para comparar cotações internas e externas. 
Para feijão, soja e milho, os preços publicados pelo IEA e pela FAO são equivalentes e se referem ào produto à granel transacionado internacionalmente. Para algodão e arroz as cotações se referem a produtos diferentes e alguns ajustes são necessários. Os preços da FAO são para algodão èm pluma e arroz beneficiado, enquanto os do IEA se referem a algodão em caroço e arroz :em casca. Para encontrar um preço equivalente, ajustou-se levando em conta os coeficientes físicos de transformação e os custos de beneficiamento. Os coeficientes 2,1342 para arroz e 2,857 para algodão foram baseados nas publicações da CFP(36).

Os custos de beneficiamento para arroz e algodão foram ajustados com base nos dados da CFP para a região Centro-Sul. No algodão, o melhor critério encontrado foi a razão entre preço mínimo do algodão em pluma e preço mỉnimo do algodão em caroço (já ajus tado pelo coeficiente de transformação).

Para o arroz, pela inexistência de preço mínimo para arroz beneficiado, usou-se o critério de deflacionar os valores de custo de beneficiamento publicado pela CFP (Apêndice 2). Este método, se bem que imperfeito, é melhor que não considerar o custo de beneficiamento.

$\mathrm{Na}$ transformação das cotações internacionais em dôla res para o valor em cruzeiros, utilizou-se a taxa de câmbio média

(36) Preços mínimos. Regiões Centro-Oeste, Sudeste e Sul. Safra 75/ 76. 
ponderada publicada pela Fundação Getūilio Vargas (Apêndice 3, Tabe1a 39).

As Tabelas 1 e 2 mostram os preços interno e externo dos produtos, respectivamente.

Tabela 1 - Preços correntes mêdios recebidos pelos produtores. São Paulo, 1968-1978. Cr\$/ton.

\begin{tabular}{rrrrrr}
\hline ANO & $\begin{array}{c}\text { Arroz } \\
\text { Beneficiado }\end{array}$ & $\begin{array}{c}\text { Algodão } \\
\text { em PIuma }\end{array}$ & Feijão & Milho & Soja \\
\hline 1968 & 889,00 & $1.378,00$ & 414,00 & 113,00 & 271,00 \\
1969 & 954,00 & $1.634,00$ & $1.016,00$ & 174,00 & 341,00 \\
1970 & 900,00 & $1.820,00$ & 780,00 & 200,00 & 430,00 \\
1971 & $1.669,00$ & $2.854,00$ & 970,00 & 240,00 & 550,00 \\
1972 & $1.970,00$ & $3.355,00$ & $1.320,00$ & 310,00 & 610,00 \\
1973 & $2.121,00$ & $4.797,00$ & $3.310,00$ & 460,00 & $1.200,00$ \\
1974 & $3.304,00$ & $6.857,00$ & $2.610,00$ & 550,00 & $1.180,00$ \\
1975 & $5.076,00$ & $7.092,00$ & $3.790,00$ & 800,00 & $1.330,00$ \\
1976 & $4.133,00$ & $17.761,00$ & $8.350,00$ & 990,00 & $1.840,00$ \\
1977 & $5.698,00$ & $18.184,00$ & $8.070,00$ & $1.140,00$ & $2.800,00$ \\
1978 & $10.229,00$ & $24.895,00$ & $8.370,00$ & $2.190,00$ & $3.570,00$ \\
\hline
\end{tabular}

FONTE: Instituto de Economia Agrícola (IEA). 
Tabela 2 - Preços médios de exportação. Cr\$/ton. 1968 a 1978.

\begin{tabular}{rrrrrr}
\hline ANo & $\begin{array}{c}\text { Arroz } \\
\text { Beneficiado }\end{array}$ & $\begin{array}{c}\text { Algodão } \\
\text { em Pluma }\end{array}$ & Feijão & Milho & Soja \\
\hline 1968 & 589,77 & $2.151,08$ & 586,35 & 177,27 & 351,13 \\
1969 & 644,01 & $2.510,82$ & $1.035,30$ & 224,18 & 399,45 \\
1970 & 597,22 & $2.889,63$ & $1.401,17$ & 275,64 & 473,18 \\
1971 & 628,56 & $3.660,43$ & $1.716,65$ & 332,77 & 607,43 \\
1972 & 807,02 & $4.616,65$ & $1.892,95$ & 373,84 & 747,68 \\
1973 & $1.384,48$ & $5.390,88$ & $2.223,74$ & 563,59 & $1.323,22$ \\
1974 & $2.722,74$ & $8.820,21$ & $3.673,39$ & 869,12 & $1.670,34$ \\
1975 & $3.063,50$ & $9.101,12$ & $4.111,76$ & $1.105,14$ & $1.828,35$ \\
1976 & $3.008,94$ & $13.422,86$ & $5.452,37$ & $1.312,41$ & $2.294,05$ \\
1977 & $4.001,06$ & $21.518,04$ & $8.525,21$ & $1.569,32$ & $3.859,67$ \\
1978 & $6.737,50$ & $24.728,25$ & $10.115,25$ & $2.113,37$ & $4.569,94$ \\
\hline
\end{tabular}

Fonte: Para feijão, Trade Yearbook, FAO. Para os demais produtos, The State of Food and Agricultura, FAO.

Taxa de cambio, Conjuntura Econōmica, FGV. 


\subsection{2 - Preços dos fertilizantes}

Fertilizante é um insumo com um mercado internacional ativo, concentrado em alguns produtos, e cujos ajustes podem ser feitos com base nos principais macronutrientes (N, P e K). Na análi se de cada nutriente, estudaram-se apenas os produtos que participa ram com a maior parcela do consumo nacional.

Para os fosfatados, o consumo se concentrou nos produtos super simples e super triplo, enquanto o sulfato de amônio foi o principal nitrogenado(37). No que se refere aos potássicos, todo o consumo está sendo suprido por importações (BARROS, 1980) e aproximadamente $92 \%$ a $95 \%$ de $\mathrm{K}_{2} \mathrm{O}$ são fornecidos pelo cloreto de potássio (MAlaVOLta e ROMERO, 1975). Portanto, para as estimativas dos preços de N, P e K, utilizaram-se os produtos sulfato de amônio (N), super simples e super triplo (P) e cloreto de potássio (K). No caso do fósforo, o preço do nutriente $\underline{\mathrm{P}}$ foi encontrado por uma média pon derada dos preços de super simples e super triplo, sendo o fator de ponderação o consumo interno de ambos os produtos (Apêndice 3, Tabe 1a 38). Os teores médios dos nutrientes em cada produto estão no Apêndice 3, Tabela 35. Outra alternativa de ponderação seria pelo con sumo de nutriente por produto.

0 preço interno considerado foi o pago pelos agricul tores do Estado de São Paulo, fornecìdo pelo IEA. Para o mercado in (37) BAUM (1977), Tábela 3.III, e BARROS (1980), quadro 1.12, compu taram a produção e importação dos principais fertilizantes no Brasil. 
ternacional, usou-se o preço médio CIF de importação pelo Brasil, com fonte primäria nos boletins da CACEX. Esse preço é tomado como o preço efetivo que se pagaria pelos nutrientes importados na hipótese de livre comércio. As Tabelas 3 e 4 mostram os preços internos e externos ao longo do período considerado.

Tabela 3 - Preços anuais médios dos nutrientes $\mathrm{N}, \mathrm{P}_{2} \mathrm{O}_{5}, \mathrm{~K}_{2} \mathrm{O}$ pagos pelos agricultores do Estado de São Paulo. Cr\$/kg. 1968 a 1980 .

\begin{tabular}{cccc}
\hline ANO & $\begin{array}{c}\text { NITROGENIO } \\
(\mathrm{N})\end{array}$ & $\begin{array}{c}\text { POTÁSSIO } \\
\left(\mathrm{K}_{2} \mathrm{O}\right)\end{array}$ & $\begin{array}{r}\text { FöSFORO } \\
\left(\mathrm{P}_{2} \mathrm{O}_{5}\right) \\
\text { Ponderado* }\end{array}$ \\
\hline 1968 & 0,85 & 0,33 & 0,82 \\
1969 & 1,15 & 0,39 & 0,98 \\
1970 & 1,14 & 0,46 & 1,05 \\
1971 & 1,38 & 0,64 & 1,16 \\
1972 & 1,81 & 0,72 & 1,66 \\
1973 & 2,57 & 0,91 & 2,16 \\
1974 & 8,10 & 1,84 & 6,07 \\
1975 & 8,76 & 2,25 & 6,75 \\
1976 & 6,95 & 2,56 & 7,14 \\
1977 & 9,00 & 3,26 & 8,38 \\
1978 & 12,90 & 4,62 & 10,33 \\
1979 & 19,95 & 8,07 & 16,52 \\
1980 & 47,05 & 23,51 & 41,14 \\
& & & \\
\hline
\end{tabular}

FONTE: Instituto de Economia Agrícola (IEA).

* Ponderado pelo consumo interno de superfosfato simples e superfos fato triplo. 
Tabela 4 - Preços anuais médios de importação dos nutrientes $\mathrm{N}, \mathrm{P}_{2} \mathrm{O}_{5}$ e $\mathrm{k}_{2}$ 0. Cr\$ $/ \mathrm{kg} \cdot 1968$ a 1980 .

\begin{tabular}{cccc}
\hline ANO & $\begin{array}{c}\text { NITROGÊNIO } \\
(\mathrm{N})\end{array}$ & $\begin{array}{c}\text { POTÁSSIO } \\
\left(\mathrm{K}_{2}\right)\end{array}$ & $\begin{array}{r}\text { FÓSFORO } \\
\left(\mathrm{P}_{2} 0_{5}\right) \\
\text { Ponderado* }\end{array}$ \\
\hline 1968 & 0,57 & 0,19 & 0,54 \\
1969 & 0,65 & 0,22 & 0,66 \\
1970 & 0,49 & 0,27 & 0,65 \\
1971 & 0,50 & 0,37 & 0,80 \\
1972 & 0,91 & 0,40 & 1,02 \\
1973 & 1,35 & 0,45 & 1,45 \\
1974 & 3,87 & 0,76 & 3,94 \\
1975 & 3,46 & 1,16 & 3,47 \\
1976 & 2,50 & 1,16 & 3,02 \\
1977 & 4,60 & 1,54 & 4,07 \\
1978 & 6,89 & 2,22 & 6,32 \\
1979 & 11,44 & 4,44 & 11,06 \\
1980 & 28,83 & 13,45 & 29,29 \\
& & & \\
\hline
\end{tabular}

FONTE: Sindicato da Indústria de Adubos e Corretivos do Estado de São Paulo (SIACESP) com dados primärios da CACEX.

* Ponderado pelo consumo interno de super simples e super triplo.

A alternativa de ponderação pelo consumo de nutriente fornecido por cada produto não afeta significativamente os resultados, porque os preços do nutriente $P$ no super simples e no super triplo são próximos, tanto no mercado interno como no externo. Por outro lado, apesar da participação crescente no mercado de outros produtos como o DAP e MAP, o super triplo e super simples conjuntamente representaram $70 \%$ e $50 \%$ do consumo de fosfatados no Brasil nos anos 1965 e 1978 respectivamente. 


\subsection{3 - Preço dos derivados do petrōleo}

A Tabela 13, mostrando a participação dos diviersos ítens que compõem o custo diārio de um trator indica a importância dos derivados de petróleo, mormente depois da crise de 1973 e da mu dança para utilização de tratores de maior potência.

o propósito de considerar todo o setor da mecanização ficou restrito aos derivados óleo diesel e graxa e seus usos em tratores de roda. Apesar de importantes nos custos, não se computaram os efeitos da depreciação (preço e qualidade) dos custos de reparos e dos custos de capital representando os custos fixos. A prio ri, é de se esperar que a não inclusão dos efeitos da depreciação e dos custos de reparos subestime uma possível taxação incorporada ao setor de máquinas. A menor qualidade de nossas máquinas implica num custo adicional de reparos e maior depreciação. Assim, mesmo que não se tenha uma proteção nominal (38) para a indústria de tratores, exis te uma proteção efetiva determinada por estes fatores que compõem :o custo diārio das operações mecanizadas.

Para o ôleo diesel, adotou-se como preço domésticco o preço pago pelos agricultores do Estado de São Paulo. Para preços no mercado internacional consideraram-se as cotações fornecidas pela revista Petroleum Economist, calculando uma mẻdia anual CIF tomando preços mensais. Com relação à graxa, tomou-se como preço ex-

(38) Estudos da ANAGRI (1980) indicam que a relação preço interno/ preço externo, de tratores similares, em períodos recentes, va riou de 0,38 a 0,92 . 
terno o preço paģo pelos agricultores americanos. Para o mercado in terno inexistem cotações para São Paulo, e tomou-se uma média dos preços pagos pelos produtores do Rio Grande do Sul, Paraná, Santa Catarina, Espírito Santo e Rio de Janeiro, Estados das regiões Sul e Sudeste.

0 que pode ser questionado è a adoção dos preços da graxa pagos pelos agricultores americanos como uma "proxi" para pre ço no mercado internacional. Para este derivado, os melhores dados, em termos de sērie histórica, foram publicados pelo USDA. 0 preço americano, como uma medida do preço em uma hipótese de livre comércio, parece razoável pela importância dos EUA na produção, consumo e comercialização de petróleo e derivados em todo o mundo. 0 principal, entretanto, é o efeito que o uso deste preço pode gerar em sub ou superestimar a TPE. Se se admite que os preços americanos são estimativas superiores dos preços em livre comércio, o efeito é uma TPE superestimada. Por outro lado, se se pensa que aqueles preços são estimativas inferiores dos preços em livre comércio, tem-se uma TPE subestimada.

Apesar disso, os efeitos que tais diferenças podem causar nas estimativas da TPE são pequenos, como se notará no capítulo seguinte.

da graxa.

(39) USDA. Agricultural Statistics. 


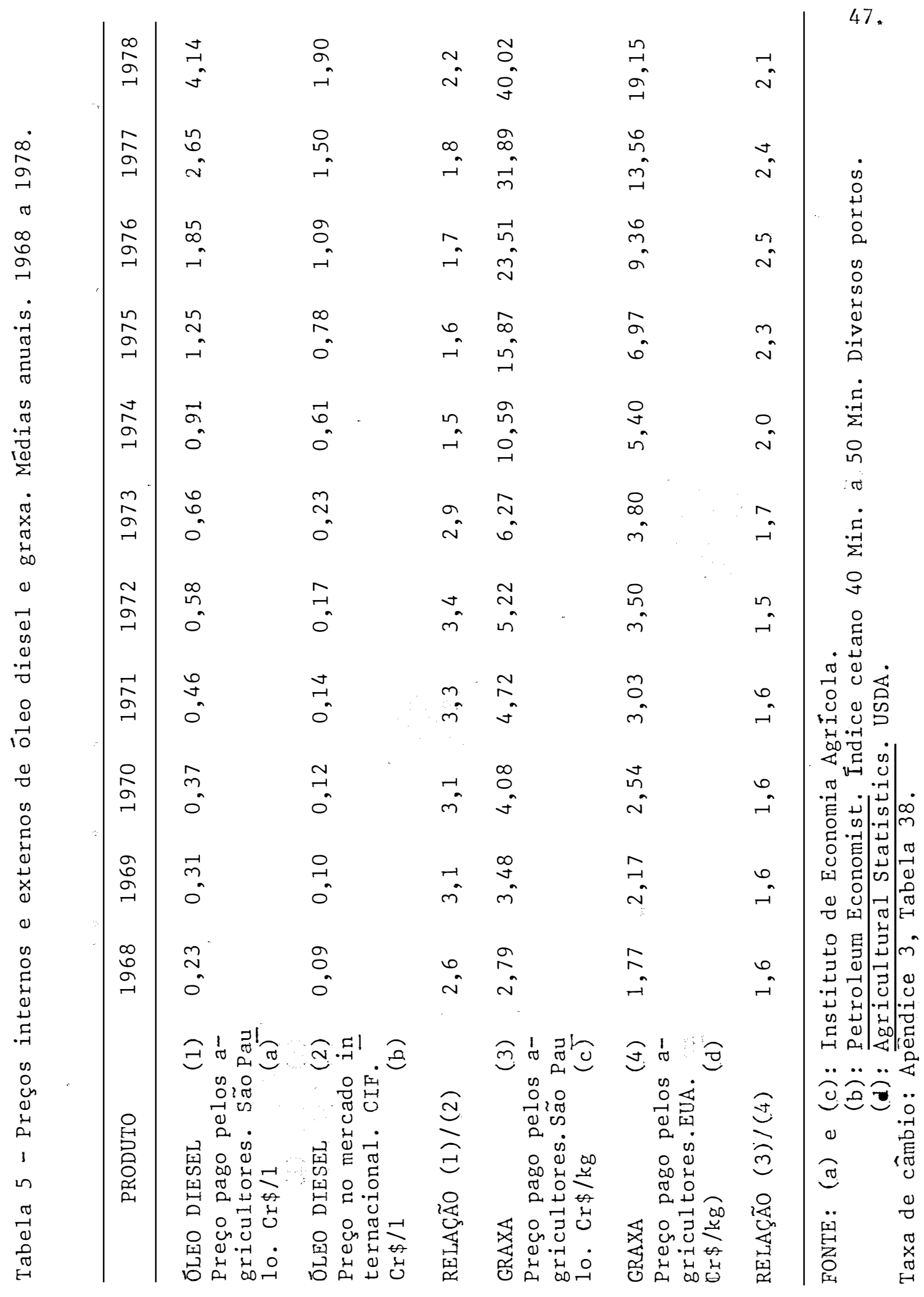




\section{2 .4 - Custo de transporte}

Ao estimar a TPE a partir de observações de preço, comparamos os preços recebidos pelos produtores com os preços médios de exportação (FAO). Pode-se argumentar, entretanto, que uma análise mais realista teria que incluir os custos de transporte des de o produtor até o porto exportador (ponto periférico).

No entanto, esta argumentação precisa ser encarada de forma diferente, dependendo da natureza do produto, ou seja, se ele é do subsetor doméstico ou do subsetor exportador.

Para o subsetor dóméstico a alternativa que se pode colocar é a da importação do produto contra sua aquisição no mercado interno. Neste caso, o ponto de referência se localizaria, além do porto exportador, nos centros nacionais de maior consumo, no caso as concentrações urbanas. Se o custo de conduzir a mercadoria até os centros consumidores principais, desde o porto ou outros pontos de entrada, é maior que desde os produtores, a taxa de proteção resultará subestimada, posto que não se considera a "proteção natural" que proporciona o custo de transporte. E vâlida a conclusão oposta, se os gastos de transporte desde as fazendas superam as despesas que incorre desde os portos ${ }^{(40)}$. Portanto, quando não se consideram os custos de transporte envolvido nas operações desde os portos e desde os produtores, hā uma compensação, que é tanto menos tendenciosa quanto mais próximos estiverem aqueles custos de transporte.

(40) Raciocínio similar para o setor industrial, ver BAIASSA (1971). 
Para os produtos de mercado externo, em que a comercialização é feita ao nível de porto, ou seja, não se coloca a alternativa de importação do produto, existe a necessidade de acrescentar às cotações recebidas pelos produtores, os custos envolvidos no transporte até o porto exportador.

Para o algodão e a soja, tentou-se aproximar estes custos de transporte, tomando-se as cotações destes produtos ao nivel de atacado em São Paulo. A diferença entre estas cotações e as recebidas pelos produtores, representaria uma aproximação razoável para os custos de transporte até o porto exportador. No cálculo das TPE para os produtos de exportação, se adotaram dois preços distintos, os recebidos pelos produtores e os preços no atacado em são Pau 1o. Esta ültima cotação se encontra na Tabela 6 .

Tabela 6 - Preços médios anuais de venda no mercado atacadista, cidade de São Paulo, 1968 a 1978. Cr\$/ton.

\begin{tabular}{lcc}
\hline & \multicolumn{2}{c}{ PRODUTOal } \\
\cline { 2 - 3 } ANO & Algodão & Soja \\
\hline 1968 & $1.697,00$ & 329,00 \\
1969 & $1.685,00$ & 440,00 \\
1970 & $2.331,00$ & 538,00 \\
1971 & $3.121,00$ & 645,00 \\
1972 & $3.439,00$ & 763,00 \\
1973 & $5.593,00$ & $1.414,00$ \\
1975 & $7.095,00$ & $1.439,00$ \\
1976 & $7.268,00$ & $1.456,00$ \\
1977 & $18.607,00$ & $2.080,00$ \\
1978 & $18.941,00$ & $2.954,00$ \\
& $25.698,00$ & $3.817,00$ \\
\hline
\end{tabular}

FONTE: Comissão de Financiamento da Produção (CFP). Anuārios Estatísticos.

a) Para algodão, preços disponíveis no mercado de São Paulo, tipo 6, origem: São Paulo. Em 1977 e 1978 tipo 5. Para soja, preços no atacado para o tipo industrial. 


\section{3 - Coeficientes Técnicos}

\subsection{1 - Nota sobre o conceito de custo de produção do IEA}

As estimativas de custos do IEA são as únicas disponíveis no Brasil em termos de série temporal e de uso de critérios homogêneos para o seu cálculo. O conceito de custo operacional adotado a partir de 1972 difere do conceito clássico de custos fixos e variáveis. O custo de produção antes usado levava em conta todos os componentes ligados direta ou indiretamente ao processo produtivo. Os critérios subjetivos de remuneração dos fatores fixos levaram a estimativas imprecisas. Em muitas dessas estimativas o custo de pro dução superou o preço do produto, indicando que o produtor deveria abandonar a atividade. (41)

Em vista disso, o IEA mudou para o conceito de custo operacional, composto pelos ítens de custo considerados variáveis e pelos custos fixos representados pela depreciação dos bens duráveis, mão-de-obra familiar, além de impostos e taxas. Esse conceito aten-

deu à pretensão de se ter um parâmetro de curto prazo e que não con trariasse os princípios da teoria da firma.

Para manter maior homogeneidade nos cálculos, nos anos em que faltavam estimativas de custo operacional, usaram-se es timativas de despesas diretas, as quais diferem do custo operacional pela exclusão dos ítens fixos.

(41) MATSUNAGA et alii (1976) quantifica, para alguns produtos, essa afirmação. 
Nas estimativas de custos encontram-se os coeficientes técnicos (independentes do conceito de custo, pois são levantados em trabalho de campo). Essas estimativas foram utilizadas para se achar as participações relativas dos insumos modernos durante os anos. Algumas ressalvas poderiam ser feitas acerca dessa participação do tripé de insumos modernos nos custos da agricultura, porque a exclusão ou inclusão de ítens segundo o modelo considerado afetaría os percentuais encontrados. Entretanto, nossa anālise està menos preocupada com valores absolutos do que com a direção dos aumen tos observados na participação daqueles fatores modernos.

\section{3 .2 - Cầculo}

Todas as estimativas dos coeficientes técnicos, para facilidade de cálculos, foram feitas para uma tonelada de produto. o exemplo a seguir toma como base os dados para a cultura de algodão, com sistema de tração motomecanizada, 102 arrobas/ha (1.530 kg/ /ha), na safra $1976 / 77$.

Do custo de produção se extrai os seguintes coeficientes técnicos:

- Fertilizantes

Sulfato de amōnio (SA) - 0,20 t

Formulado $(3-15-15)-0,38 \mathrm{t}$ 
- Defensivos

Clorados: 5,521

Sistêmico: 5,461

Herbicida: 1,99 1

Formicida (isca): $1,00 \mathrm{~kg}$

- Trator: 2,76 dias

Para transformar em exigências de insumos por tonela da de algodão em caroço, basta multiplicar os coeficientes acima pe 1o fator $1000 / 1530=0,6536$.

- Fertilizantes:

- Nitrogênio (N)

SA: $\quad 0,20 \mathrm{t} \times 0,21 \times 0,6536=27,4 \mathrm{~kg} \mathrm{~N}$

Formulado: $\quad 0,38 \mathrm{t} \times 0,03 \times 0,6536=7,4 \mathrm{~kg} \mathrm{~N}$

TOTAL $27,4+7,4=38,4 \mathrm{~kg} \mathrm{~N} / \mathrm{t}$ de algodão em caroço.

- Fósforo $\left(\mathrm{P}_{2} \mathrm{O}_{5}\right)$

Formulado: $\quad 0,38 \mathrm{t} \times 0,15 \times 0,6536=37,2 \mathrm{~kg} \cdot \mathrm{P}_{2} \mathrm{O}_{5} / \mathrm{t}$

- Potássio $\left(\mathrm{K}_{2} \mathrm{O}\right)$ :

Formulado: $\quad 0,37 \mathrm{t} \times 0,15 \times 0,6536=37,2 \mathrm{~kg} \mathrm{k}_{2} 0 / \mathrm{t}$

- Defensivos:

- Clorado: $\quad 3,601$

- Sistêmico: $\quad 3,571$ 
- Herbicida: $\quad 1,301$

- Formicida (isca): $\quad 0,65 \mathrm{~kg}$

- Trator: 1,80 dias.

Para transformar os coeficientes de algodão em caro-
ço para coeficientes de algodão em pluma multiplica-se pelo fator
2.857. (42)

4.3 .3 - Ajuste para ōleo diesel e graxa

Para inclusão desses derivados no cálculo da TPE, é necessärio transformar o coeficiente técnico de dias-máquina . para litros de óleo diesel e quilos de graxa. Nesta transformação é necessārio considerar o consumo de cáda um conforme a potência em ques tão. A estrutura de custos do IEA das diversas culturas não especifica a potência tomada como base. o ajuste consiste em encontrar uma potência de referência. Este cálculo fundamentou-se na venda de tra tores de quatro rodas no Brasil, conforme dados primärios da ANAGRI (Apêndice 3, Tabela 36). Adotou-se como potência média em uso pelos agricultores, a venda acumulada, por faixa de potência, a partir do ano de 1970. De certa forma este procedimento tende a estimar para mais a potência média. O correto seria estimar a população total de tratores e sua distribuição por potência, o que ê um dado de difícil obtenção.

(42) Coeficiente de transformação obtido nas publicações da CEP. (Pre ços Mínimos. Regiões Centro Oeste, Sudeste e Sul. Safra 75/76). 
Em cada faixa de potência da Tabela 36 , se procurou um consumo médio de óleo diesel e de graxa. Os dados primärios foram tomados dos coeficientes físicos usados no cảlculo do custo diá rio de tratores fornecidos pelo IEA, e se encontram na Tabela 7.

Tabela 7 - Coeficientes físicos de consumo de óleo diesel e graxa, por potência.

\begin{tabular}{llcccc}
\hline MARCA & $\begin{array}{c}\text { Potência } \\
\text { (HP) }\end{array}$ & $\begin{array}{c}\text { Litros de Oleo } \\
\text { Diesel/dia }\end{array}$ & $\begin{array}{c}\text { kg de Graxa/ } \\
\text { dia }\end{array}$ \\
\hline MF 50X ou MF 235 & 44 & 40 & 0,96 \\
MF 65X ou MF 265 & 56 & 50 & 0,96 \\
MF 95X ou & MF 295 & 100 & 104 & 0,96 \\
CBT 2105 & & 110 & 96 & 0,96 \\
\hline
\end{tabular}

FONTE: Instituto de Economia Agrícola (IEA).

Baseado na Tabela 7, determinou-se que as faixas de potência teriam o seguinte consumo:

$\begin{array}{cc}\begin{array}{c}\text { Litros de Óleo } \\ \text { Diesel/dia }\end{array} & \begin{array}{c}\mathrm{kg} \text { de Graxa/ } \\ \text { dia }\end{array} \\ 40 & 0,96 \\ 100 & 0,96 \\ 0,96\end{array}$

Com as estatísticas de venda de tratores de quatro rodas no Brasil, conforme a faixa de potência e do consumo de die- 
sel e de graxa mostrado acima, calcularam-se os gastos daqueles derivados em um dia-máquina durante os anos do período considerado (Apêndice 3, Tabela 40).

Este procedimento visou obter um coeficiente mais real do que simplesmente estabelecer para todos os anos um consumo fixo. A evolução do parâmetro para o óleo diesel (de 55 1/dia em 1968 para 68 1/dia em 1979) se deveu à utilização de tratores de alta po tência. O uso de potências maiores deixa implícito que hả necessida de hoje de menos dias-máquinas para produzir a mesma quantidade de produto que em anos atrás, e o procedimento poderia estimar para mais os coeficientes. Não obstante, foi frisado que os coeficientes técnicos levantados pelo IEA não refletem todas as mudanças ooorridas no período, mudanças essas causadas principalmente por fatores tecnológicos, preços e clima. O que se argumenta é que a metodologia escrita acima reflete melhor algumas dessas mudanças, pois a evolução tecnológica da agricultura brasileira tem sido de mecaniza ção crescente.

\section{3 .4 - Ponderações}

Os custos operacionais levantados pelo IEA, apesar da metodologia homogênea, ao longo dos anos variaram com respeito aos níveis tecnológicos (Tração Animal = TA, Tração Motorizada e Animal = TMA e Tração Motomecanizada $=$ TM). Além disso, para a maio- 
ria dos produtos estes custos foram levantados para mais de uma região (DIRA) e para os diversos sistemas de produção (arroz de sequeiro, arroz irrigado, feijão das secas e feijão das águas).

Nas ponderações efetuadas para o cálculo dos coeficientes técnicos, atentou-se para a ajustagem em relação aos níveis tecnológicos, regiões agrícolas e sistemas de produção. As Tabelas 8 a 11 apresentam as estimativas dos coeficientes e explicam cada ponderação, à exceção do critério com respeito à tecnologia.

Dentre todos os produtos, apenas o milho apresentada dos referentes a somente um nível tecnológico (Tração MotomecanizadaTM). Para os demais, os níveis tecnológicos adotados no começo dos anos setenta foram sendo substituídos (feijão e arroz em que TA foi trocada por TMA), ou foram sendo acrescentados outros níveis (algodão e soja que passaram a ter estimativas também para TM). Para estes produtos, a metodologia de cālculo levou em conta o maior número possível daquelas estimativas. As próprias substituições ou acrés cimos de outros níveis tecnológicos nos levantamentos de custo de produção do IEA são indicadores das transformações tẻcnicas que se processaram durante o período e a inserção de todos esses levantamentos nos coeficientes técnicos possibilitaria encontrar parâmetros mais condizentes com a realidade. Os rodapés, das Tabelas 8 a 11 es pecificam os níveis de tecnologia adotados. 
Tabela 8 - Arroz beneficiado. Coeficientes técnicos ponderados, em unidade de insumos por tonelada de produto. São Paulo. $1970 / 71$ - 1979/80.

\begin{tabular}{|c|c|c|c|c|c|c|c|}
\hline \multirow[b]{2}{*}{ ANO } & \multicolumn{3}{|c|}{ FERTILIZANTES } & \multicolumn{3}{|c|}{ DEFENSIVOS } & \multirow{2}{*}{$\begin{array}{l}\text { TRATOR } \\
\text { (dias) }\end{array}$} \\
\hline & $\begin{array}{c}\mathrm{N} \\
(\mathrm{kg})\end{array}$ & $\mathrm{P}_{2} \mathrm{O}_{5}$ & $\begin{array}{l}\mathrm{k}_{2} \mathrm{O} \\
(\mathrm{kg})\end{array}$ & $\begin{array}{l}\text { Herb. } \\
\text { (1itro) }\end{array}$ & $\begin{array}{c}\text { Inset. } \\
(\mathrm{kg})\end{array}$ & $\begin{array}{l}\text { Form } \\
\quad(\mathrm{kg})\end{array}$ & \\
\hline $1970 / 71$ a $/$ & 23,9 & 47,4 & 34,8 & - & 43,8 & - & - \\
\hline $1971 / 72$ a $/$ & 23,9 & 47,4 & 34,8 & - & 43,8 & - & - \\
\hline $1972 / 73$ al & 23,9 & 47,4 & 34,8 & - & 43,8 & - & - \\
\hline $1973 / 74$ a $/$ & 23,9 & 47,4 & 34,8 & - & 43,8 & - & - \\
\hline $1974 / 75$ al & 34,4 & 17,2 & 34,4 & - & 43,8 & - & - \\
\hline $1975 / 76 \frac{\mathrm{b} /}{}$ & 20,1 & 70,4 & 40,2 & - & - & - & 1,65 \\
\hline $1976 / 77 \mathrm{c} /$ & 102,1 & 57,2 & 105,0 & - & $1,37^{\mathrm{n}}$ & ${ }^{i} 1,5^{n i}$ & 4,23 \\
\hline $1977 / 78^{c /}$ & 102,1 & 57,2 & 105,0 & - & $1,37^{\mathrm{n}}$ & $i 1,5^{n i}$ & 4,23 \\
\hline $1978 / 79 \mathrm{c} /$ & 102,1 & 57,2 & 105,0 & - & $1,37^{\mathrm{n}}$ & i $1,5^{n i}$ & 4,23 \\
\hline $1979 / 80 \stackrel{\mathrm{d} I}{\prime}$ & 30,6 & 30,1 & 17,2 & $9^{i r}$ & $0,61^{i}$ & $r_{1,42^{n i}}$ & i 4,14 \\
\hline
\end{tabular}

a/ Refere-se ao sistema de tração animal não irrigado.

$\bar{b} /$ Para trator, tirou-se média simples dos sistemas TA e TM não irrigado.

c/ Os coeficientes foram obtidos por uma média ponderada dos sistemas de produção irrigado $(0,1)$ e de sequeiro $(0,9)$. Tais fatores de ponderação refletem a participação desses dois sistemas na pro dução total de arroz no Estado de São Paulo.

d/ A queda brusca em relação à tendência crescente dos anos anterio res que se observa nos coeficientes de $\mathrm{N}$ (102,1 kg para 30,6 kg) e de $\mathrm{K}_{2} 0$ (105,0 kg para $\left.17,2 \mathrm{~kg}\right)$ tem origem nos levantamentos do IEA, sendo que o sistema de sequeiro, com maior peso na ponderação $(0,9)$ teve seus coeficientes para fertilizantes cerca de três vezes menores na safra 1979/80.

ni/ Coeficiente referente apenas ao sistema de sequeiro.

$\overline{i r} /$ Coeficiente referente apenas ao sistema irrigado.

FONTE: Instituto de Economia Agrícola (IEA). 
58.

Tabela 9 - Aldogão em pluma. Coeficientes técnicos ponderados, em unidades de insumos por tonelada de produto. São Paulo. $1970 / 71-1979 / 80$.

\begin{tabular}{|c|c|c|c|c|c|c|c|c|}
\hline \multirow[b]{2}{*}{ ANO } & \multicolumn{3}{|c|}{ FERTILIZANTES } & \multicolumn{4}{|c|}{ DEFENSIVOS } & \multirow[b]{2}{*}{$\begin{array}{l}\text { TRATOR } \\
\text { (dias) }\end{array}$} \\
\hline & $\begin{array}{l}\mathrm{N} \\
(\mathrm{kg})\end{array}$ & $\begin{array}{l}\mathrm{P}_{2} \mathrm{O}_{5} \\
(\mathrm{~kg})\end{array}$ & $\begin{array}{l}\mathrm{K}_{2} \mathrm{O} \\
(\mathrm{kg})\end{array}$ & $\begin{array}{l}\text { Inse } \\
\text { Pó } \\
(\mathrm{kg})\end{array}$ & $\begin{array}{l}\text { ticida } \\
\text { Lĩq. } \\
\text { (kg) }\end{array}$ & $\begin{array}{l}\text { Herb. } \\
\text { (litro) }\end{array}$ & $\begin{array}{l}\text { Form. } \\
\text { (kg) }\end{array}$ & \\
\hline $1970 / 71$ a/ & 86,9 & 141,7 & 85,1 & 133,7 & 1,31 & - & - & 4,97 \\
\hline $1971 / 72$ a $/$ & 86,9 & 141,7 & 85,1 & 133,7 & 1,31 & - & - & 4,97 \\
\hline $1972 / 73$ a $/$ & 86,9 & 141,7 & 85,1 & 133,7 & 1,31 & - & - & 4,97 \\
\hline $1973 / 74$ a & 86,9 & 141,7 & 85,1 & 133,7 & 1,31 & - & - & 4,97 \\
\hline $1974 / 75^{a /}$ & 105,4 & 138,6 & 138,6 & 133,7 & 1,31 & - & - & 4,97 \\
\hline $1975 / 76^{a /}$ & 105,4 & 138,6 & 138,6 & 133,7 & 1,31 & - & - & 4,97 \\
\hline $1976 / 77^{\mathrm{b}} /$ & 96,6 & 129,7 & 129,7 & & $\begin{array}{c}13,1^{\mathrm{cl}} \\
7,1^{\mathrm{s}}\end{array}$ & 3,7 & 1,7 & 4,29 \\
\hline $1977 / 78$ - & 86,0 & 115,4 & 115,4 & & $\begin{array}{c}11,7^{\mathrm{cl}} \\
6,3^{\mathrm{s}}\end{array}$ & 3,1 & 1,7 & 3,83 \\
\hline $1978 / 79$ b & 86,0 & 115,4 & 115,4 & & $\begin{array}{c}11,7^{\mathrm{cl}} \\
6,3^{5}\end{array}$ & 3,1 & 1,7 & 4,40 \\
\hline $1979 / 80 \mathrm{~b} /$ & 86,0 & 115,4 & 115,4 & & $\begin{array}{c}11,7^{\mathrm{cl}} \\
6,3^{\mathrm{s}}\end{array}$ & 3,1 & 1,7 & 4,40 \\
\hline
\end{tabular}

a/ Os coeficientes se referem ao sistema de produção com tração motomecanizada e animal (TMA).

b/ Os coeficientes se referem a uma média simples dos sistemas de produção com tração motomecanizada (TM) e com tração motomecanizada e animal (TMA), considerando as Diras de Campinas e dé Ribeirão Preto, ponderadas igualmente, em vista da participação de ambas na produção total do Estado de São Paulo.

cl: clorado.

S: sistêmico.

FONTE: Instituto de Economia Agrícola (IEA). 
Tabela 10 - Feijão. Coeficientes técnicos ponderados, em unidades de insumos por tonelada de produto. São Paulo. 1970/71 $-1979 / 80$.

\begin{tabular}{|c|c|c|c|c|c|c|c|}
\hline \multirow[b]{2}{*}{ ANO } & \multicolumn{3}{|c|}{ FERTILIZANTES } & \multicolumn{3}{|c|}{ DEFENS IVOS } & \multirow{2}{*}{$\begin{array}{l}\text { TRATOR } \\
\text { (dias) }\end{array}$} \\
\hline & $\begin{array}{c}\mathrm{N} \\
(\mathrm{kg})\end{array}$ & $\begin{array}{l}\mathrm{P}_{2} \mathrm{O}_{5} \\
(\mathrm{~kg})\end{array}$ & $\begin{array}{l}\mathrm{K}_{2} \mathrm{O} \\
\left(\mathrm{kg}_{\mathrm{g}}\right)\end{array}$ & $\begin{array}{c}\text { Inset. } \\
(\mathrm{kg})\end{array}$ & $\begin{array}{l}\text { Herb. } \\
(\mathrm{kg})\end{array}$ & $\begin{array}{l}\text { Form. } \\
(\mathrm{kg})\end{array}$ & \\
\hline $1970 / 71$ a $/$ & 13,1 & 46,2 & 25,4 & - & - & - & - \\
\hline $1971 / 72$ a & 13,1 & 46,2 & 25,4 & - & - & - & - \\
\hline $1972 / 73$ b/ & 8,0 & 72,1 & 15,8 & - & - & - & 0,89 \\
\hline $1973 / 74 \mathrm{~b} /$ & 12,1 & 42,7 & 23,2 & 0,23 & 0,21 & - & 0,79 \\
\hline $1974 / 75$ b & 7,3 & 74,9 & 28,4 & 0,23 & 0,21 & - & 0,79 \\
\hline $1975 / 76 \mathrm{cl}$ & 11,0 & 38,3 & 21,9 & $1,02^{\mathrm{a}}$ & 0,46 & 1,4 & 2,65 \\
\hline $1976 / 77 \stackrel{\mathrm{d} /}{-}$ & 11,6 & 40,4 & 23,1 & $0,68^{\mathrm{ag}}$ & 1,15 & 1,52 & 2,47 \\
\hline $1977 / 78^{d /}$ & 11,6 & 40,4 & 23,1 & $0,68^{\mathrm{ag}}$ & 1,15 & 1,52 & 2,47 \\
\hline $1978 / 79 \underline{d} /$ & 14,2 & 49,8 & 28,4 & $4,29^{\mathrm{ag}}$ & 2,88 & 1,19 & 2,00 \\
\hline $1979 / 80$ d/ & 13,8 & 48,3 & 27,6 & 3,75 & 2,58 & 1,21 & 2,08 \\
\hline
\end{tabular}

a/ Os coeficientes se referem ao sistema de produção com tração animal (TA).

b/ Os coeficientes se referem a uma média simples dos sistemas de pro dução com tração animal (TA) e tração motomecanizada e animal (TMĀ).

cf Os dados disponíveis se referem ao sistema de produção com tração motomecanizada e animal (TMA) em cultivo na seca ( $\mathrm{Se}$ ).

d/ Os coeficientes foram obtidos do sistema de produção com tração motomecanizada e animal (TMA) considerando os cultivos das àguas e da seca, ponderados igualmente, em vista da participação iguali täria dos dois cultivos na composição da produção total do Estado de São Paulo.

ag: O coeficiente se refere ao cultivo das águas.

FONTE: Instituto de Economia Agrícola (IEA). 
Tabela 11 - Milho. Coeficientes técnicos ponderados, em unidades de insumos por tonelada de produto. São Paulo. 1970/71 $-1979 / 80$.

\begin{tabular}{|c|c|c|c|c|c|}
\hline \multirow{2}{*}{ ANO } & \multicolumn{3}{|c|}{ FERTILIZANTES } & \multirow{2}{*}{$\begin{array}{c}\text { DEFENS IVOS } \\
\begin{array}{c}\text { Formicida } \\
(\mathrm{kg})\end{array}\end{array}$} & \multirow{2}{*}{$\begin{array}{l}\text { TRATOR } \\
\text { (dias) }\end{array}$} \\
\hline & $\begin{array}{c}N \\
(k g)\end{array}$ & $\begin{array}{l}\mathrm{P}_{2} \mathrm{O}_{5} \\
(\mathrm{~kg})\end{array}$ & $\begin{array}{l}\mathrm{K}_{2} \mathrm{O} \\
(\mathrm{kg})\end{array}$ & & \\
\hline $1970 / 71$ a $/$ & 10,1 & 16,7 & 5,1 & - & 0,52 \\
\hline $1971 / 72$ a/ & 13,4 & 22,2 & 6,8 & - & 0,90 \\
\hline $1972 / 73$ a/ & 13,4 & 22,2 & 6,8 & - & 0,90 \\
\hline $1973 / 74 \mathrm{~b} /$ & 15,2 & 14,0 & 8,0 & - & 0,90 \\
\hline $1974 / 75^{\mathrm{a} /}$ & 15,2 & 14,0 & 8,0 & - & 0,90 \\
\hline $1975 / 76$ b/ & 15,2 & 14,0 & 8,0 & - & 0,90 \\
\hline $1976 / 77$ a & 18,5 & 17,1 & 9,8 & - & 1,23 \\
\hline $1977 / 78$ a/ & 18,5 & 17,1 & 9,8 & - & 1,23 \\
\hline 1978/79a & 18,5 & 17,1 & 9,8 & - & 1,23 \\
\hline $1979 / 80$ al & 18,5 & 17,1 & 9,8 & - & 1,23 \\
\hline
\end{tabular}

a/ Os coeficientes disponiveis se referem ao sistema motomecanizado de produção estimado para o Estado de São Paulo.

b/ Não havia dados disponíveis e adotaram-se os coeficientes do ano $1974 / 75$.

FONTE: Instituto de Economia Agrícola (IEA). 
Tabela 12 - Soja. Coeficientes técnicos pronderados, em unidade de insumos por tonelada de produto. São Paulo. 1970/71 $-1979 / 80$.

\begin{tabular}{|c|c|c|c|c|c|c|c|}
\hline \multirow[b]{2}{*}{ ANO } & \multicolumn{3}{|c|}{ FERTILIZANTES } & \multicolumn{3}{|c|}{ DEFENSIVOS } & \multirow[b]{2}{*}{$\begin{array}{l}\text { TRATOR } \\
\text { (dias) }\end{array}$} \\
\hline & $\begin{array}{c}\mathrm{N} \\
(\mathrm{kg})\end{array}$ & $\begin{array}{l}\mathrm{P}_{2} \mathrm{O}_{5} \\
(\mathrm{~kg})\end{array}$ & $\begin{array}{l}\mathrm{K}_{2} \mathrm{O} \\
(\mathrm{kg})\end{array}$ & $\begin{array}{l}\text { Inse } \\
\text { Pó } \\
(\mathrm{kg})\end{array}$ & $\begin{array}{l}\text { icida } \\
\text { Líq. } \\
\text { (1itro) }\end{array}$ & $\begin{array}{l}\text { Herb. } \\
\text { (1itro) }\end{array}$ & \\
\hline $1970 / 71$ a/ & - & 41,7 & - & 11,4 & 0,63 & - & 1,14 \\
\hline $1971 / 72$ a/ & - & 41,7 & - & 11,4 & 0,63 & - & 1,14 \\
\hline $1972 / 73$ a & - & 41,7 & - & 11,4 & 0,63 & - & 1,14 \\
\hline $1973 / 74$ a & - & 37,4 & - & - & 1,52 & - & 0,91 \\
\hline $1974 / 75$ b / & - & 22,7 & 7,6 & 28,3 & - & - & 0,91 \\
\hline $1975 / 76^{\mathrm{c}}$ / & - & 22,7 & 7,6 & 28,3 & - & - & 0,91 \\
\hline $1976 / 77^{\mathrm{b} /}$ & - & 34,4 & 11,5 & - & 1,76 & - & 0,75 \\
\hline $1977 / 78$ b/ & - & 34,4 & 11,5 & - & 1,76 & - & 0,75 \\
\hline $1978 / 79$ b / & - & 34,4 & 11,5 & - & 1,76 & - & 0,75 \\
\hline $1979 / 80$ b / & - & 91,7 & 30,6 & - & 0,91 & 1,00 & 0,81 \\
\hline
\end{tabular}

a/ Os dados disponíveis se referem ao sistema de produção com tração motomecanizada e animal.

b/ Os dados apresentados se referem ao sistema de produção com tração motomecanizada.

c/ Para o ano 1975/76 não haviam dados disponíveis e adotaram-se os dados do ano anterior (1974/75).

FONTE: Instituto de Economia Agrícola (IEA). 


\section{1 - Custo Diário de Tratores e Custos de Produção}

Na Tabela 13 encontram-se os resultados da participa ção dos diversos ítens no custo diário de tratores de quatro rodas. Há variações ao longo das safras $1970 / 71$ a 1980/81 e segundo a potência (HP).

Para todas as potências houve uma participação crescente dos percentuais dos ítens combustíveis (coluna 2) e da soma de combustíveis, lubrificantes e graxa (coluna 4). Para as potências menores ( $44 \mathrm{HP}$ ), esses derivados do petróleo que eram responsáveis por cerca de $42 \%$ do custo total do início da década passaram para 53\% no final dos anos 70 (safra 1978/79). No que se refere às médias e altas potências, as participações daqueles îtens também au- 
mentaram. Na safra $1975 / 76$ foi de $50,7 \%$ e 50,8\%, respectivamente,para média e alta potência, passando para $71,4 \%$ e $72,7 \%$ no início da década de 80 (safra 1980/81).

Quanto ao ítem depreciação (coluna 5), observa-se uma participação minoritária e decrescente de seus percentuais. No cálculo da depreciação se leva em conta os fatores durabilidade da máquina, dias de uso anual (escala de operação) e os preços de compra e venda. Portanto, o preço de compra da máquina é um ítem que na ver dade pouco contribui para o custo diário, e sua inclusão somente nos cálculos da TPE, como se pretendia inicialmente, captaria pequena parcela dos subsídios ou taxações que realmente estariam ocorrendo. Os derivados diesel, lubrificantes e graxa têm maior poder de subsi diar ou taxar o setor agrícola, pela condição de majoritários na par ticipação dos custos diärios de tratores. Essa condição se acentuou ao longo da ültima década, quer pelo aumento substancial dos preços daqueles derivados, quer pelo uso crescente de tratores de mẻdia e alta potências (veja Apêndice 3, Tabela 36), em que o peso daqueles componentes é visivelmente maior do que nos tratores de baixa potên cia. Esses fatos corroboram a importāncia da política governamental de preço de combustíveis para o setor agropecuário.

Uma ressalva, entretanto, deve ser feita quanto à par ticipação do îtem preço de compra da mäquina no custo diário de tra tores. Neste aspecto, a metodologia de cálculo de custo empregado pe 1o IEA näo incorporam as partes relativas ao fator fixo, ou seja, 
ao custo de oportunidade do capital empregado na compra de tratores. A inclusão desse fator aumentaria a importância do preço de compra de máquinas nos custos diários em detrimento dos outros ítens. Não obstante, deve-se ter em mente que a política de crédito rural, com juros subsidiados, funcionou no sentido de diminuir a incidência des ses custos fixos, sendo que quanto maior o valor absoluto dos subsỉdios, menor foi a participação dos custos de oportunidade do capi tal nos custos diários de tratores. Isto, entretanto, não significa uma solução aả hoe para não inclusão dos custos de capital nos custos diārios, mas apenas uma qualificação importante para o entendimento do problema.

Na análise dos custos de produção dos diversos produtos (Apêndice 1), observa-se que o tripé de insumos modernos (ferti lizantes, defensivos e tratores) vem aumentando sua participação. Em mëdia, a participação desses insumos chegou a corresponder a $50 \%$ dos custos operacionais das cinco culturas nas ültimas safras.

Essa majoração, causada pelo maior uso desses insumos, em consequência de uma maior modernização do setor e pelos aumentos dos seus preços, principalmente depois do primeiro choque do petróleo em 1973, evidencia o comprometimento das políticas do setor industrial para com a agricultura, em vista de que alguns desses insumos modernos estão ligados ao processo de substituição de importação. 
65.

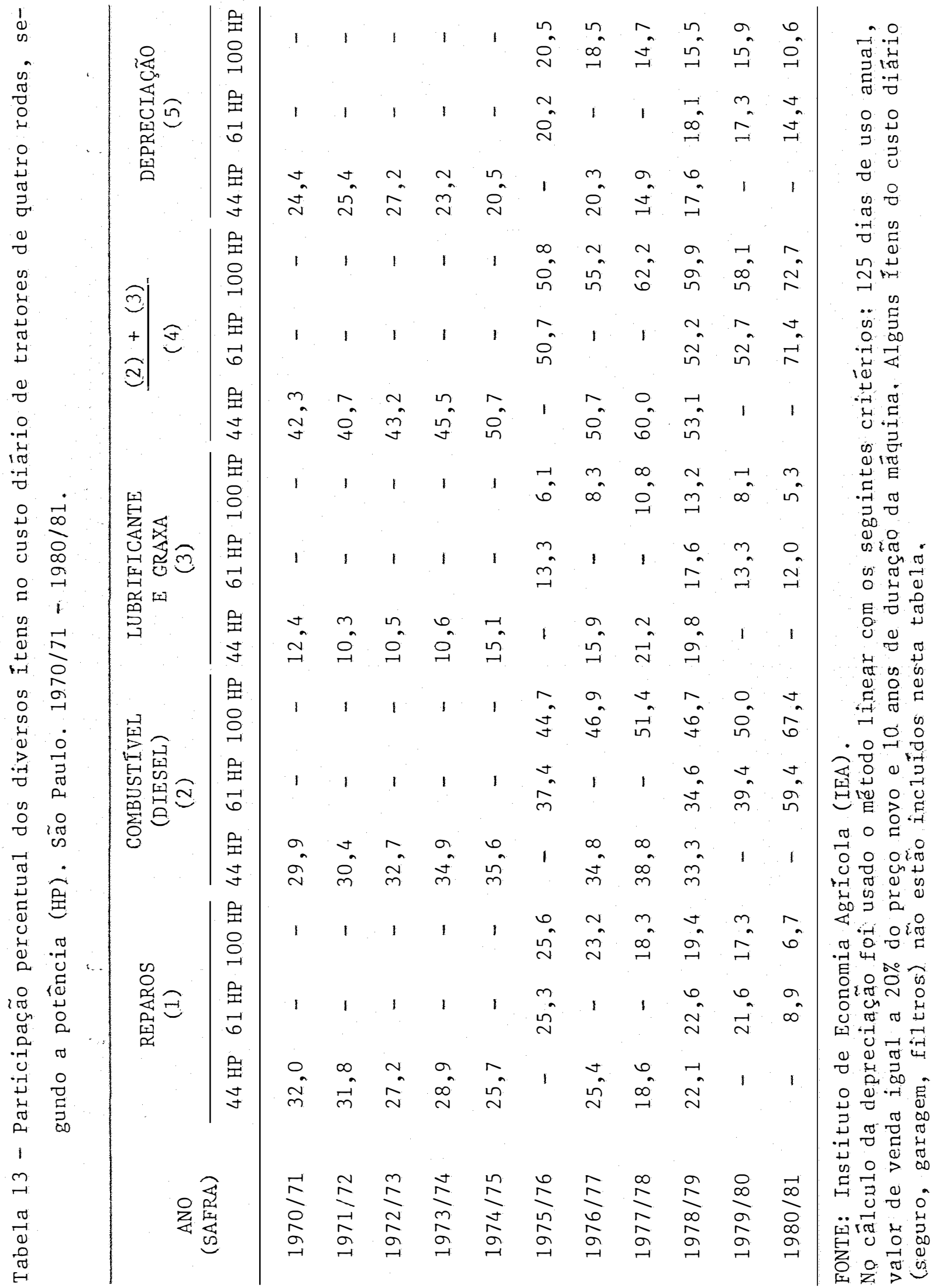


66.

\section{2 - Tarifa de Proteção Efetiva (TPE)}

No Capítulo 3 foi explicado que a TPE engloba, no seu conceito, a proteção ou taxação de todo o processo produtivo, ou se ja, dos produtos e dos insumos necessärios na produção. Nesse senti do, é possivel separar o componente referente ao preço do produto ou Proteção Nominal (PN), da componente referente aos insumos e produ tos conjuntamente (TPE). A separação desses componentes nos dirā em que direção a política industrial (fornecedora dos insumos modernos) beneficia ou taxa o setor agrícola.

Nas Tabelas 14 a 18 encontram-se para cada produto,e durante o período de 1968-1978, os resultados da Proteção: Nominal (PN) e da Proteção Efetiva (TPE). Convém ressaltar que as taxas efe tivas calculadas não incluiram, por falta de dados, o setor de defensivos e de tratores (preço e qualidade) e esta exclusão pode sub estimar os resultados. Nos grä́ficos 1 e 2 se visualiza melhor a estrutura de proteção para as cinco culturas, notando que apenas o ar roz teve TPE positiva em todos os anos. Para os demais produtos (ex cessão algodão em 76 e feijão em 73 e 76), as TPE foram negativas. Ao se comparar a Proteção Nominal (PN) com a taxa de Proteção Efetiva (TPE) evidencia-se que todos os produtos, e durante todo o período, tiveram uma taxação adicional dada pelo setor de in sumos. O comportamento da TPE foi sempre de declinar a PN, stornando-a mais negativa ainda. Somente o arroz, nos anos 71,72 e 78 te- 
ve uma TPE superior à PN. Não obstante, a comparação dos custos em livre comércio com custos com protecionismo (colunas 1 e 2 , respectivamente), nos referidos anos, revelou uma desproteção ao setor.

Portanto, a condição desfavorável da relação de preços internos/preços internacionais foi reforçada pela política de proteção dos setores industriais. Os preços dos produtos ocupam posição de componente majoritärio, o que lhe dá poder de dirigir a mag nitude das taxas de proteção e compensar possíveis discriminações pe lo lado dos insumos, fato que não ocorreu.

O arroz mostrou uma PN e TPE positivas, embora estas ūltimas, de maneira geral, inferiores às primeiras: A explicação pạ ra este fato pode ser devida a dois fatores. O primeiro estaria ligado a política comercial restritiva a importações, que afeta o fun cionamento dos mercados. No setor de produtos domésticos temos um mercado funcionando em uma economia fechada, ou seja, apenas a demanda e oferta internas determinam preço e quantidade. Nesta situação, tem-se condições para manter os preços domésticos acima daqueles prevalecentes no mercado internacional.

O segundo fator é o fato das cotações agrícolas nos mercados internacionais sofrerem a influência tanto dos países exportadores (subsídios, quotas, estoques reguladores, etc.) como dos países importadores (restrições, proibições, entre outros). Estas interferências no comércio podem gerar preços externos que nãocor respondem aos verdadeiros custos de produção dos países. JOHNSON 
68.

(1973), em uma análise qualitativa, alegou a hipótese de produtos como açücar, manteiga e arroz estarem com preços subsidiados e que a retirada das interferências no comércio causaria um aumento substancial em suas cotações. Em uma situação menos restritiva, as taxas nominais e efetivas seriam menores. Este argumento, entretanto, não invalida o argumento de uma taxação do consumidor, porquanto a alternativa de importar o produto a uma cotação subsidiada è, na prā tica, viāvel.

Quanto à tendência, não houve um comportamento geral uniforme para as atividades. O que se observa $\bar{e}$ que para alguns pro dutos (arroz, milho e soja), teve-se uma queda nas TPE, enquanto ou tros (algodão e feijão) tiveram ascenção, em perỉodos recentes (ver figuras: 1 e 2). E nítido, entretanto, a queda brusca que sofreram em suas taxas efetivas após o ano de 1973, para depois se recuperarem. A subida dos preços dos produtos no mercado internacional e a crise do petróleo que elevou bruscamente o preço dos insumos modernos, principalmente dos países dependentes (43), influiram para que isso ocorresse.

A escala de proteção no período foi definida em termos totais, isto é, as áreas cheias nas figuras representam a prote ção total para o período. Nesses termos, os produtos de maior impor

(43) Com relação a fertilizantes, ver ANJOS e NORONHA (1974). A alta dos preços no mercado brasileiro foi bem superior ao registrado no mercado norte-americano. 
tância nutricional, arroz e feijão, foram os que apresentaram as maiores proteções, enquanto soja e algodão ocuparam uma posição intermediäria. o milho foi o produto com menores TPE.

HOMEM DE MELO (1981) destaca a subdivisão do setor agrïcola entre um subsetor exportador e un subsetor doméstico, como um fator que pode modificar parte das conclusões acerca das discriminações em termos de preço ${ }^{(44)}$. Analisa a proteção nominal (PN: re lação de preços internos/preços externos), para os dois subsetores, no período que se estende de 1948 a 1977.

Com sua anālise, e tomando apenas o perỉodo mais recente (1968/77), alguns confrontos podem ser feitos em relação aos resultados aqui obtidos. Naquela pesquisa foram encontradas para o arroz taxas nominais sempre positivas. O feijão, entretanto, apresentou taxas em sua maioria positivas, ainda que algumas próximas de zero e outras negativas. A Tabela 15 confirma as taxas nominais encontradas para o arroz. Mesmo as TPEs se mostram positivas e em sin tonia com as PNs encontradas por HOMEM DE MELO.

No feijão, entretanto, os resultados, tanto da TPE quanto PN, foram significativamente inferiores, mesmo que semelhantes em anos isolados. No estudo acima citado, a PN média para o período $68 / 77$ foi $+0,39$, enquanto as TPE e PN médias apresentadas na Tabela 16, para o mesmo período, foram $-0,14$ e $-0,09$, respectivamen te.

(44) Os mecanismos de formação de preços são diferentes para os dois setores. O setor interno funciona como uma economia fechada. 


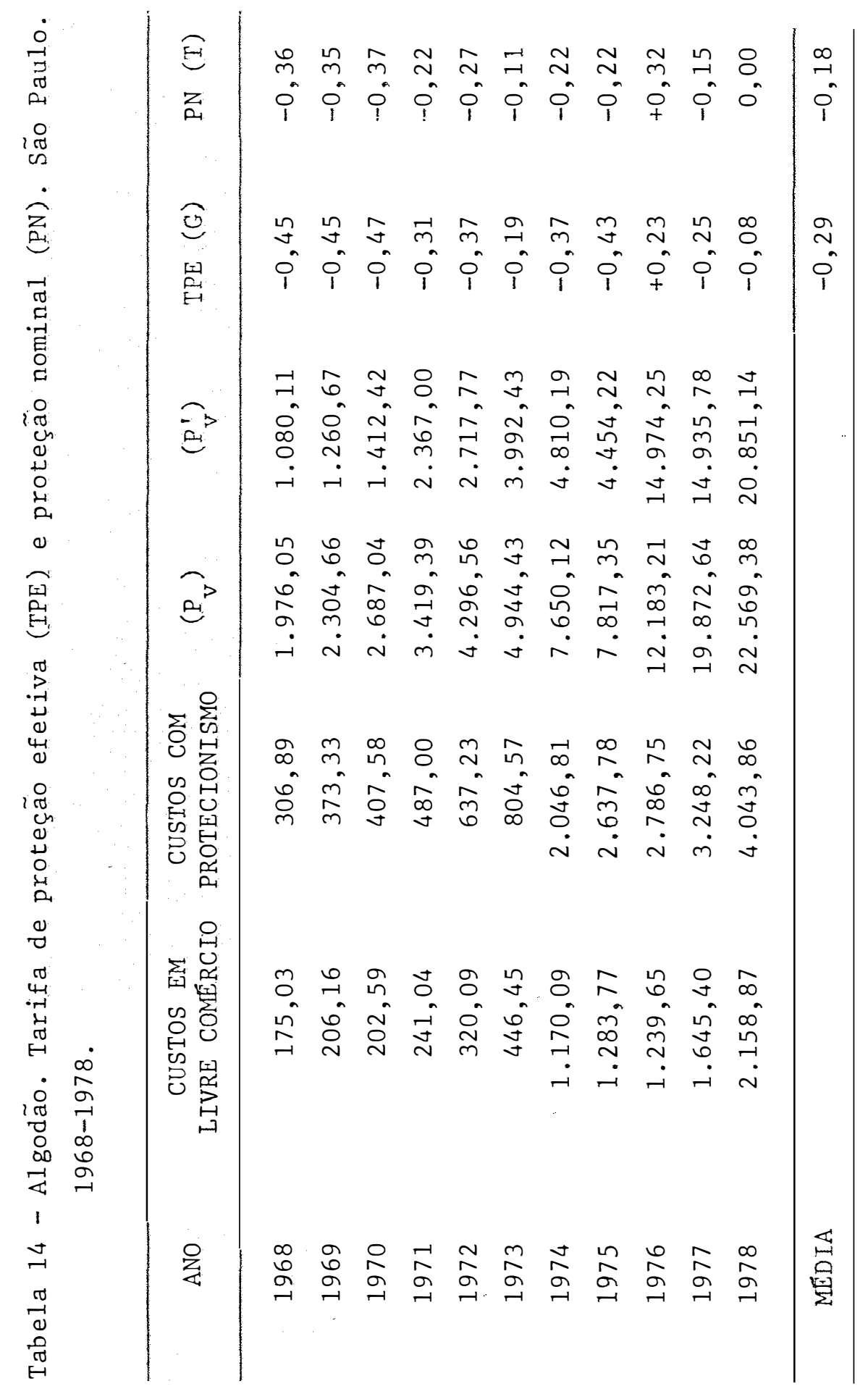


71.

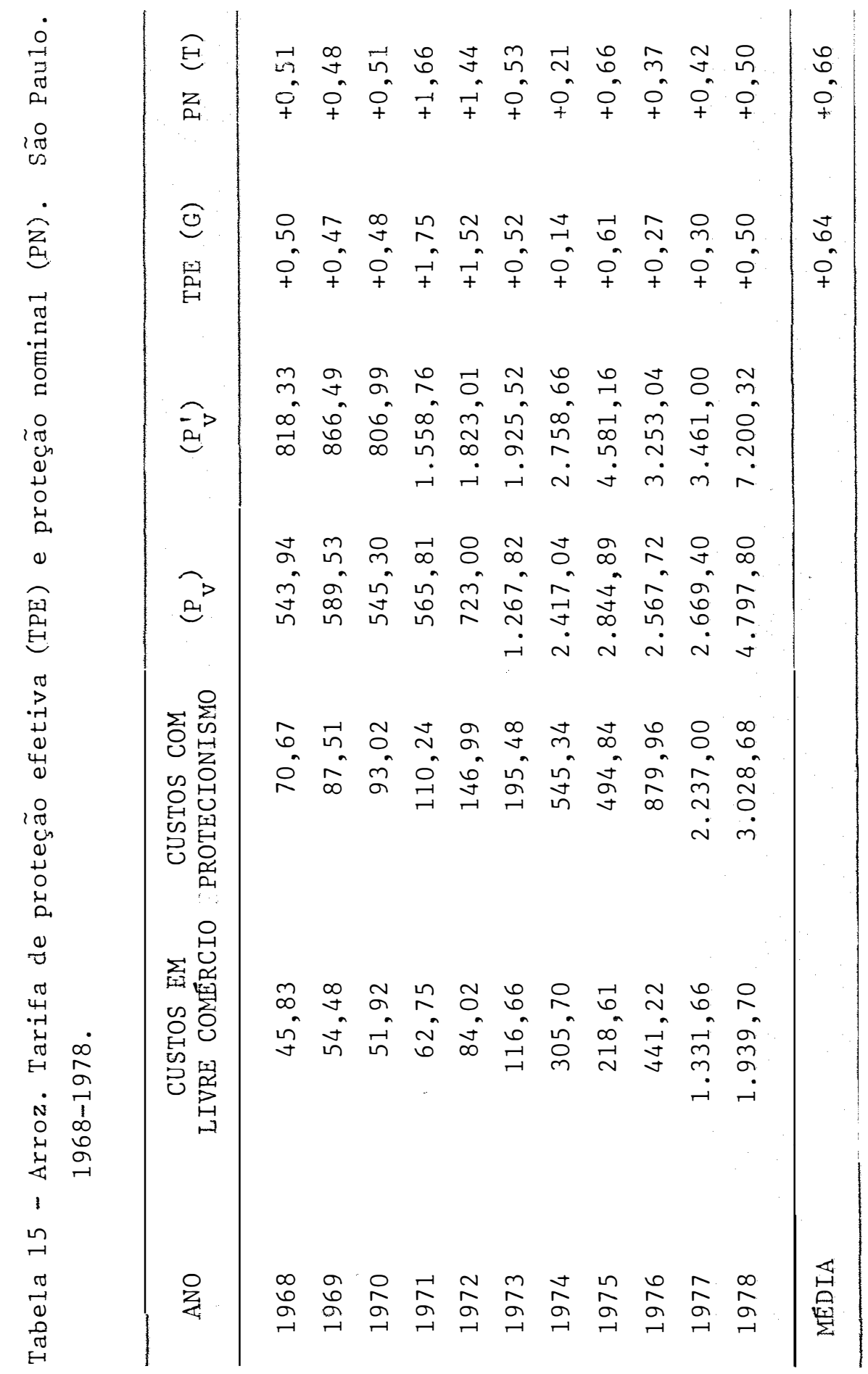


72.

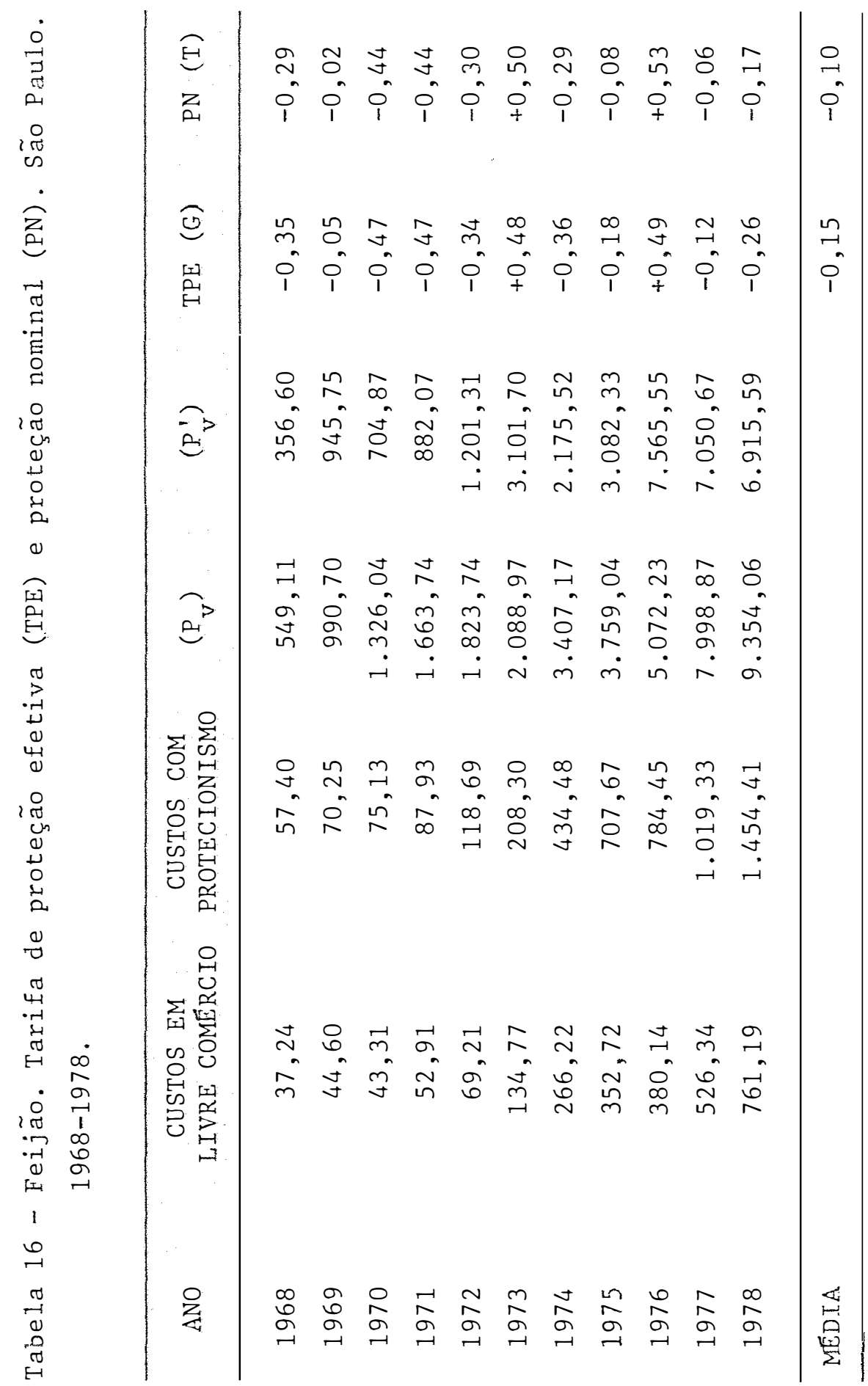


73.

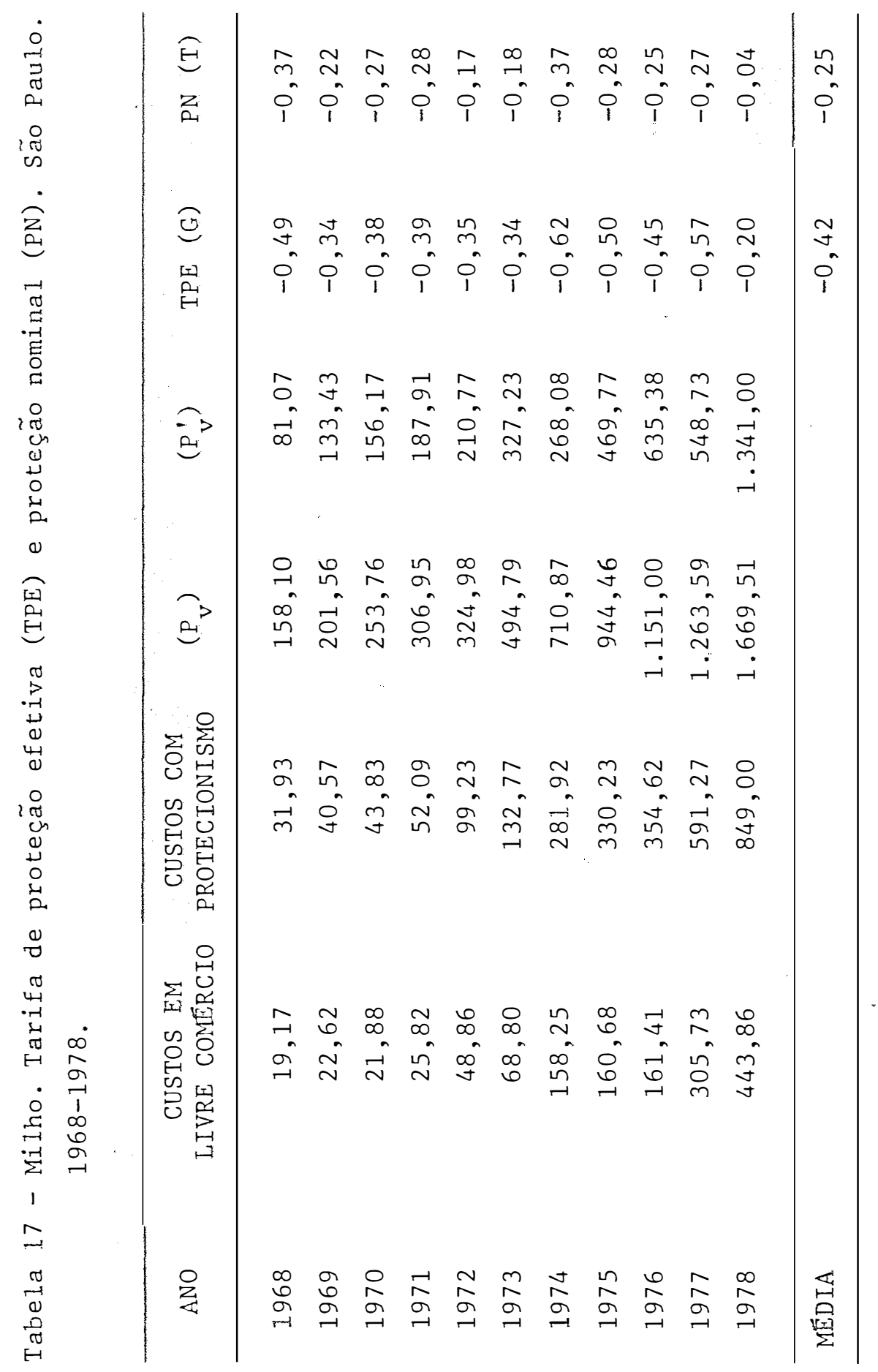




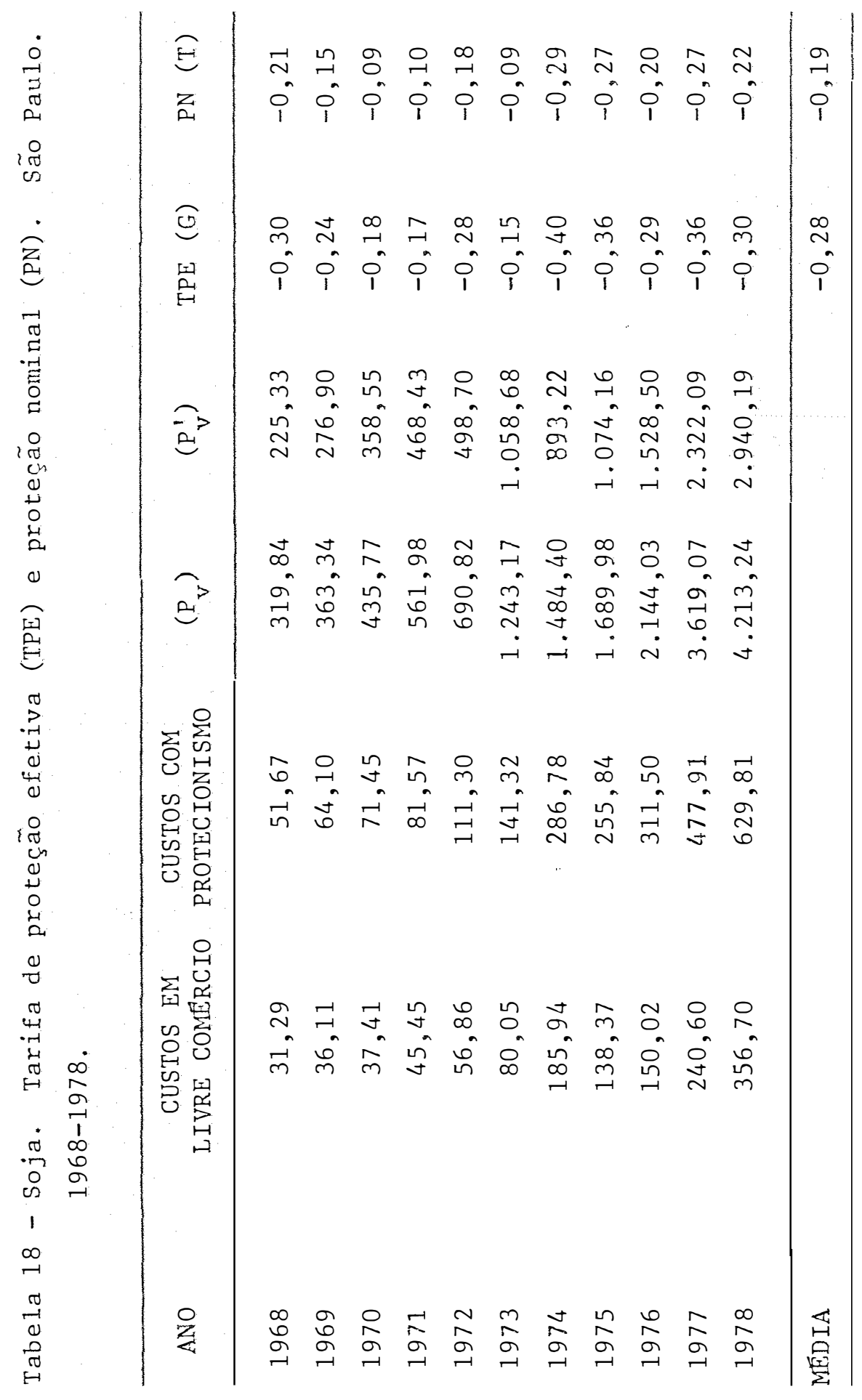



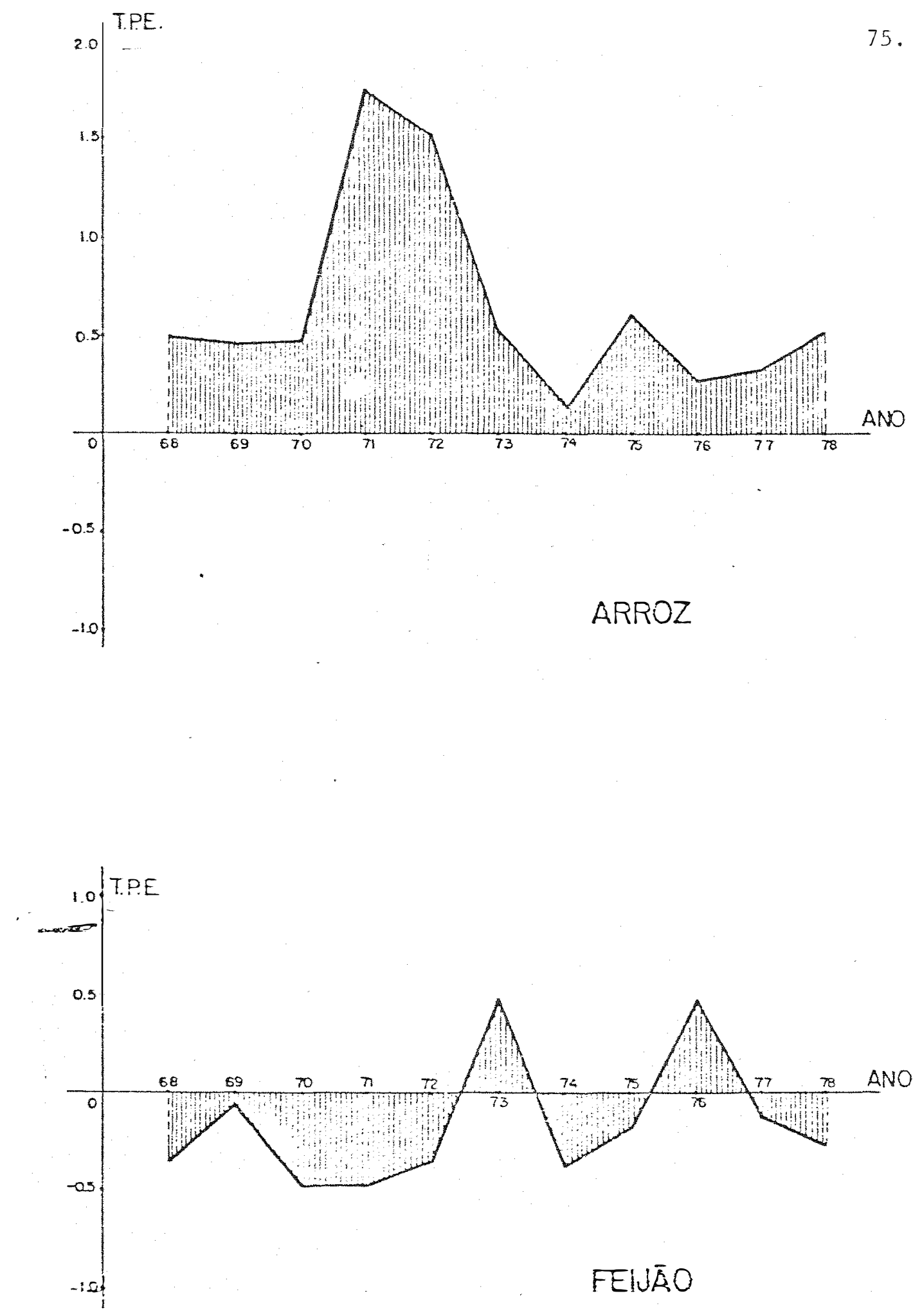

Figura 1 - Arroz e feijão. Tarifa de Proteção Efetiva (TPE). 1968$-1978$. 

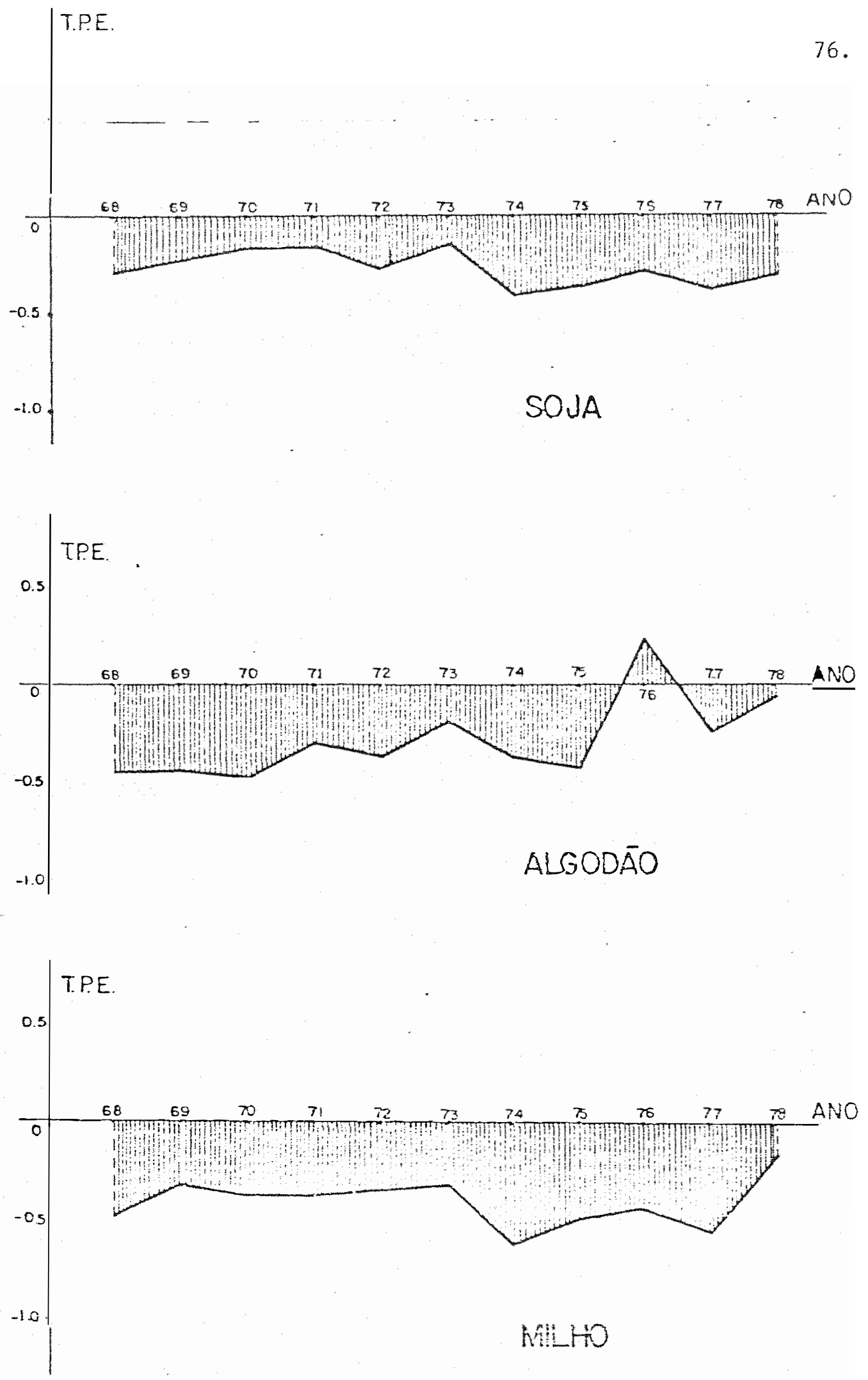

Figura 2 - Soja, algodão e milho. Tarifa de Proteção Efetiva (TPE). 1968-1978. 
Para o milho, notou-se equivalência dos resultados dụ rante o período em estudo. Enquanto, naquele, a PN média foi -0,27, neste, as TPE e PN apresentadas se situaram em $-0,44$ e $-0,27$, respectivamente. A TPE mais baixa $(-0,44)$ em comparação com as duas PN $(-0,27)$, mostra o caso típico de que a introdução do conceito de Pro teção Efetiva pode trazer novos elementos de taxação do setor.

A lista de produtos pesquisados naquele estudo englo bava mais atividades do ramo doméstico, incluindo a batata e a cebo 1a. Batata e cebola se mostraram com PN médias positivas $(+0,22$ e $+0,35$ respectivamente). Jā o amendoim, um produto intermediārio, apresentou PN média negativa $(-0,50)$, relativas ao período $68 / 77$.

A inclusão desses produtos domêsticos apresentando ta xas nominais positivas (batata e cebola) poderia servir como argumentação de que grande parte do setor domêstico foi protegida. Sem embargo, a importância relativa, tanto em termos alimentares como or çamentários, está concentrada nos produtos arroz, feijão e milho (45). Além disso, em 1978, estes três produtos ocuparam 86\% da área colhi da com produtos domésticos no Estado de São Paulo, enquanto a batata e cebola perfizeram 2,2\%. O milho e o feijão, atividades com TPE negativas, ocuparam cerca de $70 \%$ da ärea cultivada ${ }^{(46)}$.

(45) ALVES E VIEIRA (1978) mostraram que o arroz e o feijão eram res ponsáveis por $35 \%$ das calorias e $39 \%$ das proteínas consumidas por famílias de baixa renda (até um salário mínimo per capita). HOMEM DE MELO (1981), en estimativa preliminar baseada no ENDEF (1974/75), calcula que 10-20\% do total de dispêndios de familias com renda inferior a dois salários mínimos referem-se a produtos como arroz, batata, feijão, milho e cebola.

(46) Baseado nos dados do IEA (Previsões e Estimativas das Safras Agrícolas do Estado de São Paulo, 50 levantamento, junho de 1978). Com relação ao valor da produção, milho, arroz e feijão perfize ram $49 \%$, batata e cebola $27 \%$ e milho e feijão $41 \%$, todos relat vos à safra 77/78. (Produtos considerados: arroz, milho, feijão, batata, cebola, mandioca, tomate e amendoim). 
Por isso, as conclusões a respeito do grau das taxações, tanto dos consumidores quanto dos agricultores, devem levar em conta, além dos valores da TPE em si, a importância relativa dos diversos produtos, tanto em termos de área colhida e valor da produ ção, como em termos orçamentários e nutricionais. No nosso caso,dos dois produtos domésticos analisados, arroz e feijão, importantes tan to em termos de produção como de consumo pela população brasileira, os nossos resultados mostraram, mais claramente, proteção aos produtores e taxação dos consumidores, no caso do arroz apenas. O feijão apresentou TPE e PN negativas, exceto em dois anos.

Quanto aos produtos de exportação, os resultados para o algodão e soja, com TPE e PN negativas, reforçam as conclusões de uma taxação do setor.

Para o algodão, contudo, a tendência a partir de 1976 parece se inverter um pouco, onde aparecem taxas de PN positivas em confronto com longo período de taxas negativas (ver Figura 2). A se paração desses dois períodos mostra a perda de competitividade do algodão brasileiro no mercado internacional, o que, de certa forma, coincide com a queda de exportações deste produto nos últimos anos. (47)

(47) Os volumes exportados em 1976 (5.579 t), 1977 (34.732 t) e 1978 $(41.400 \mathrm{t})$ foram substancialmente menores que a média histórica dos últimos 27 anos (136,082 t). Além dos preços. não competitivos, os custos que agravam as exportaçōes primárias (só o ICM atinge $13 \%$ do valor FOB) dificultam a penetração do produto brasileiro (CFP, Relatório Anual 1978). Uma qualificação importante se refere à proteção efetiva dada nas etapas de processamento (tecidos), o que vale também para a soja (ỏleo e sub-produtos). Um estudo nesse sentido é importante para entender não só a redução das exportações primārias, como também as taxações im postas via preço do produto. 
A industria de fertilizantes é ilustrativa como exem plo de um insumo que carregou taxações para o setor agrícola. Pelas características de indüstria nascente, o setor de fertilizantes foi protegido durante todo seu processo de substituição de importação. BAUM (1977) encontrou, para 1976 e 1977 proteção efetiva positiva em alguns produtos intermediärios (48). o contigenciamento, o controle de preços e a estrutura tarifāria (49) proporcionaram uma reserva de mercado para as firmas que se implantavam. Se, por um lado,esse pro cesso de substituição de importações trouxe economias externas e de mais benefícios da industrialização, por outro constitui-se num ônus para a agricultura, na forma de preços mais elevados pagos pelos agricultores $(50)$.

A taxa de câmbio utilizada nesta pesquisa foi uma taxa de câmbio oficial. Existe o argumento de vários autores (ZOCKUM, PASTORE, LOPES e SCHUH), de que a taxa de câmbio no Brasil esteve sobrevalorizada em muitos períodos após a segunda guerra mundial. Argumentam, aiṇda, que este fato funcionou como uma taxação im plícita para as exportações agrícolas, visto que diminuiram suas re munerações. Antes de 1968, estudos de KNIGHT (1971) e BERGSMAN(1970) quantificaram esta sobrevalorização através da estimação de uma ta-

(48) Os produtos analisados foram: super simples, super triplo, DAP, MAP, uréia e nitrato de amônio. Todos com TPE positivas.

(49) ZOCKUM et alii (1976) assinala o tratamento preferencial dos in sumos modernos, que nos anos 1968-1975 receberam pouca tributação.

(50) Confronte as Tabelas 3 e 4. BARROS (1980) confirma este diferencial de preços. Ver Tabela 14. 
xa de câmbio de equilíbrio (51). Após 68 foi introduzido o sistema de minidesvalorização cambial. Segundo LOPES e SCHUH (1979), a evidência empírica também sugere que o cruzeiro esteve sobrevalorizado nes te período. Citam o estudo de LEMGRUBER (1976), que quantifica os valores da sobrevalorização através da Paridade do Poder de Compra ${ }^{(52)}$.

Não obstante, autores existem que colocam esta problemática em termos mais amplos. HOMEM DE MELO (1981), analisando as estimativas de uma taxa de câmbio de equilíbrio, argumenta que considerar a existência de proteção tarifäria e subsídios “à produção como geradoras de taxa de câmbio distorcida (sobrevalorizada) ignora a possibilidade de presença de motivações econômicas (economias dinâmicas internas e externas), justificadoras da proteção. A prote ção concedida a diversos setores industriais pode ter tido uma justificação alocativa em termos do argumento da indústria infante.

Mesmo não considerando como uma distorção, entendendo esta como uma discrepância entre custos e benefícios sociais e privados, introduzida pela política comercial, não se pode questio-

(51) Basicamente, a taxa de câmbio de equilî́brio seria aquela que equilibraria a balança de pagamentos após a eliminação das medidas protecionistas (livre comércio). BALASSA (1971) desenvol ve matematicamente a metodologia e mostra as pressuposições e dificuldades teóricas daquele instrumento".

(52) A idéia básica consiste no cálculo de uma taxa de câmbio de pa ridade, que é encontrada quando se considera a diferença entrē a inflação interna do paîs em questão e a inflação mundial, to mando-se uma série temporal a partir de um ano base. OFFICE $\bar{R}$ (1976), em um trabalho de revisão, salienta as limitações e uti lidades desta teoria. 
nar, enfocando o lado dos custos, o ônus sofrido pelo setor agrícola. Assim, ainda que se argumente que os subsídios e tarifas concedidos aos setores industriais trouxeram, para a economia como um to do, mais benefícios que custos e, ainda que estes mecanismos se jus tifiquem pelo argumento da indústria nascente, não parece existir dúvidas que houve, especificamente para o setor agrícola, um custo ditado pela sobrevalorização cambial.

Se por um lado esta sobrevalorização cambial, pelas dificuldades conceituais e de estimação que ambos os métodos citados acima apresentam, não permite, com rigor, quantificar uma TPE compensada (Capítulo 3), por outro autoriza afirmar a direção do viés que a exclusão dessa sobrevalorização acarreta. Assim, para os produtos onde a TPE é positiva (caso do arroz), a fórmula convencio nal ñão compensada superestima o grau de proteção efetiva, jä que ignora o fato da sobrevalorização cambial neutralizar parte da proteção tarifäria concedida. Nos setores de exportação (soja, algodão), onde a TPE é negativa, a sobrevalorização cambial atua como uma taxação adicional às exportações (53). Uma taxa de câmbio sobrevalorizada tende a subestimar a conversão dos preços dos insumos e dos pro dutos do mercado internacional quando do cálculo da TPE. Se por um lado a componente dos insumos (custos em livre comércio) se eleva ao se considerar o grau de sobrevalorização, por outro, a componen-

(53) NEUHAUS (1977) usa este raciocínio para os setores industriais exportador e de substituição de importações. 
te do produto fica maior e em proporção superior à primeira, de maneira que o resultado será um preço efetivo em livre comércio $\left(\mathrm{P}_{V}\right)$ mais elevado do que aquele que não considera a sobrevalorização.Com $\mathrm{P}_{\mathrm{V}}$ maiores teríamos TPE menores do que as encontradas.

Ao lado de todos esses comentários acerca das medidas que puniram o setor agrícola, deve-se colocar também a contrapartida das medidas compensatórias, tais como o crédito agrícola sub sidiado, o subsidio a fertilizantes e as atividades de pesquisa agrícola e extensão rural. A análise teria sido impossível se preten desse levar em conta todos esses mecanismos de política. O subsỉdio implícito que este conjunto de políticas carrega para a agricultu彑 ra poderia servir de argumento de que as taxações impostas pelas po Iíticas de industrialização estariam contrabalançadas.

No entanto, quando se atẻm a uma perspectiva de longo prazo e aos custos e benefícios daquelas políticas compensatórias, os resultados parecem menos promissores. Este è o caso dos sub sídios de fertilizantes, de duração efêmera e com altos custos sociais $(54)$.

A introdução dos subsídios do crédito rural tambēm possui seus desdobramentos. Suas questões distributivas, tanto regionais e por cultura, quanto setoriais, podem gerar elementos que

(54) ANJOS e NETO (1980) estimaram a relação custo/benefício para a política de subsídios aos fertilizantes. Esta relação estaria entre 0,74 e 1,645, dependendo dos parâmetros de elasticidade da produção e dos percentuais de subsídios diretos. 
modifiquem parte das conclusões de que somente o setor agrícola apropriou dos benefícios via subsídios. Segundo LOPES (1979), o crédito de comercialização é um caso de apropriação setorial duvidosa, pois, conferido ao intermediārio, beneficiador, industrial ou expor tador, destina-se a financiar o setor industrial, que não poderia absorver de uma só vez, sem ônus financeiro, uma produção que se concentre na safra. Esse ônus financeiro, que se repartiria entre consumidores, industriais e agricultores, é absorvido pelo governo através do subsídio à comercialização, cujos benefícios, portanto, se repartem entre estes mesmos grupos e não se concentram somente na agricultura.

Finalmente, a atividade de pesquisa agrîcola, com sua capacidade de carregar benefícios para o setor agrícola, será objeto de análise do subcapítulo:5.3.

\section{2 .1 - Custo de transporte}

Como descrito no Capítulo 4, os produtos do subsetor de exportáveis, soja e algodão, tiveram suas TPE e PN calculadas tam bém com a inclusão dos custos de transporte atê o porto. Estes custos de transporte são aproximados, pois foram estimados pela diferença entre os preços no mercado atacadista de São Paulo e os preços recebidos pelos produtores do Estado de São Paulo.

A Tabela 19 mostra as TPE e PN, para algodão e soja, 
quando se consideram aqueles custos de transportes. Como esperado; houve aumentos da TPE e PN para ambos os produtos e para todos os anos estudados. Para o algodão notou-se, entretanto, um aumento menos significativo em relação à soja. Enquanto as TPE e PN mẻdias au mentaram, respectivamente de $-0,29$ e $-0,18$ para $-0,26$ e $-0,11$, as da soja passaram de $-0,28$ e $-0,19$ para $-0,12$ e -0,05.

Tabela 19 - Tarifa de Proteção Efetiva (TPE) e Proteção Nominal(PN), com a inclusão dos custos de transporte. São Paulo. 1968 a 1978.

\begin{tabular}{cccccc}
\hline \multirow{2}{*}{ ANO } & \multicolumn{2}{c}{ SOJA } & \multicolumn{2}{c}{ ALGODÃO } \\
\cline { 2 - 3 } \cline { 5 - 6 } & TPE & PN & & TPE & PN \\
\hline 1968 & $-0,11$ & $-0,06$ & & $+0,29$ & $-0,21$ \\
1969 & $+0,03$ & $+0,10$ & & $-0,43$ & $-0,32$ \\
1970 & $+0,07$ & $+0,13$ & & $-0,28$ & $-0,19$ \\
1971 & 0,00 & $+0,06$ & & $-0,23$ & $-0,15$ \\
1972 & $-0,06$ & $+0,02$ & & $-0,35$ & $-0,26$ \\
1973 & $+0,02$ & $+0,07$ & & $-0,03$ & $+0,04$ \\
1974 & $-0,22$ & $-0,14$ & & $-0,34$ & $-0,20$ \\
1975 & $-0,29$ & $-0,20$ & & $-0,41$ & $-0,20$ \\
1976 & $-0,18$ & $-0,09$ & & $+0,30$ & $+0,39$ \\
1977 & $-0,32$ & $-0,23$ & & $-0,21$ & $-0,12$ \\
1978 & $-0,24$ & $-0,16$ & $-0,03$ & $+0,04$ \\
\hline MËDIA & $-0,12$ & $-0,05$ & $-0,26$ & $-0,11$ \\
\hline
\end{tabular}


o importante è que a inclusão dos custos de transpor te no câlculo das Tarifas de Proteção Efetiva e Proteção Nominal pa ra os produtos de exportação alterou significativamente os valores encontrados quando aqueles custos não foram incorporados. A soja, por exemplo, apresentou aumentos com certa proporção, tornando posí tivas para värios anos do período.

A introdução dos custos de transporte em nossa anāli se, se bem que aproximada por razões estatísticas, pôde trazer mais elucidações das vantagens comparativas dos produtos agrícolas do que dos argumentos de proteção ou desproteção do setor, incorporado nas TPE e PN. Isto se dá porque o prōprio setor de comercialização externa de produtos agrïcolas tem sido um elemento de taxação da agri cultura. Neste sentido, existe carência de infra-estrutura de expox tação e isto tem sido obstáculo para que os produtos agrícolas brasileiros alcancem os preços no mercado internacional. Exemplo disso è a exportação de soja no Paranâ. Em 1275, um estudo da Comissão de Financiamento da Produção identificou as deficiências brasileiras no setor de transporte e portuário. Este estudo mostrou que o total de despesas até o porto era três vezes superior aos custos americanos. ${ }^{(55)}$

Além deste fato, os custos de transporte de carga no Brasil parecem ser superiores aos prevalecentes em muitos países.

(55) Citado por HOMEM DE MELO e ZOCKUN (1977). 
Isto ocorre devido a dois fatores. Primeiro, a concentração excessiva de nossa estrutura de transporte de carga no transporte rodoviärio (56). Este transporte jầ $\vec{e}$, por razões intrínsecas, menos efi ciente em termos de toneladas-quilômetros por unidade de combustivel consumido. Como se analisou antes, os preços internos do princí pal combustível funcionam como um fator a mais para aumentos dos cus tos nacionais em relação aos demais países. Segundo, a esses fatores associam-se a composição da frota rodoviäria (concentrada em ca minhões leves e médios, mais ineficientes em termos energéticos) e a baixa utilização da capacidade dinâmica existente em termos de to nelada-quilômetro oferecida, gerando viagens ociosas (HOMEM DE MELO e FONSECA, 1981).

Ao fazer constar os custos de transporte em uma anälise, deve-se atentar para a superioridade destes custos, em relação a muitos países, pelas prōprias características desse sistema de transporte de carga.

Por ủltimo, a participaçäo dos custos de transporte na composição dos custos de produção agrícola não deve ser desprezí vel, mas que não está incorporada nos levantamentos desses custos de produção (57).

(56) Na dẻcada de setenta, a participação do transporte rodoviário no total das cargas foi, em média, de 70\%. Em 1976 a média mun dial era de $22,4 \%$. Veja HOMEM DE MELO e FONSECA (1981), tabelas 50 e 52 .

(57) Refiro-me aos custos de locomoção até a fazenda e custos de transporte de insumos até as propriedades (óleo diesel, fertilizantes e defensivos). 
87.

\section{3 - Tecnologịa e Taxação da Agricultura}

As discussões e resultados apresentados na subseção anterior tiveram como propósito levantar algumas das taxações impos tas à agricultura, via política comercial, através do cômputo da Ta xa de Proteção Efetiva, a qual possibilitou considerar tanto os pre ços de produtos como os preços de insumos utilizados no processo pro dutivo. Nesta parte do trabalho se procurará tratar das questões re lativas à geração de inovações tecnológicas entre os diversos produ tos, visando qualificar o argumento de alguns autores sobre a utili dade dessas inovações durante um período em que o setor primário agrícola fica desprotegido.

O que se pretende é fazer um resumo das pesquisas que mediram as disparidades relativas entre as várias culturas no que concerne à criação de inovações técnicas pelas diversas instituições püblicas. As limitações e parcialidades de muitos pontos aqui colocados são, antes, inerentes àquelas pesquisas, as quais se procurará explicitar.

As inovações tecnológicas aplicáveis ao setor agríco la podem ser classificadas em cinco categorias (58): a) vegetal-bio-

(58) Veja EVENSON (1974). 
88.

lógica; b) animal-biolōgica; c) guímica; d) mecânica; e) administra tiva. Dentro do escopo dos trabalhos desenvolvidos, apenas as inova ções tecnológicas do tipo vegetal-biológica foram pesquisadas. Além disso, levou-se em conta somente as contribuições de pesquisa das instituições püblicas.

A categoria vegetal-biológica abrange as pesquisas relativas às präticas culturais, como ensaios de adubação, espaçamento, época de plantio, até os melhoramentos genéticos incorporados em novas variedades. Esta categoria engloba a maioria das pesquisas não incorporadas a insumos (química e mecânica). Ademais, há maneiras de quantificar estas inovações entre os diversos produtos, ao contrārio do que ocorre com as categorias c, d, e. Quanto às ins tituições envolvidas, para a grande maioria dos produtos, as entida des públicas foram sempre as grandes responsāveis pela geração de inovações vegetal-biológicas. Isto se deve, fundamentalmente, às ca racterísticas dos resultados dessas pesquisas como bens püblicos ou como bens com efeitos externos significativos (59). Assim, para os produtos considerados e para a categoria vegetal-biológica, a inclu são apenas dos resultados de pesquisa proveniente de instituições go vernamentais parece representativa.

o levantamento da geração das diversas inovações tēc nicas seguirá duas metodologias. A primeira, aproveitando os traba-

(52) Se fosse deixado às forças de mercado, a quantidade oferecida seria inferior à ótima, pois os ganhos privados são menores do que os ganhos sociais (HONEM DE MELO, 1980). 
lhos que computaram o numero de publicações de pesquisa nas diversas revistas especializadas. Esta contagem das publicações será uma tentativa de quantificar os esforços de pesquisa entre produtos ao longo do tempo. $(60)$

A segunda metodologia seguirá critérios qualitativos de estudos que visaram uma abordagem histórica da geração de novas tecnologias para cada produto, assim como os impactos na resolução de problemas específicos de cada cultura. O somatório dessas duas me todologias permitirá uma visão melhor das disparidades entre produ tos e das falhas tecnológicas dentro de cada um deles.(61)

Antes de entrar nos levantamentos dos aspectos tecno lógicos propriamente ditos, se fará um comentārio sobre a Teoria da Proteção Efetiva no seu propósito de prever a alocação de recursos entre atividades. Se comentarā, tambēm, a influência da tecnologia agrícola como fator importante no direcionamento destes recursos en tre as culturas.

Como uma das finalidades da Teoria da Proteção Efeti va, foi ressaltado o propósito de se obter uma escala de proteção pạ ra as atividades envolvidas. Segundo esta teoria, a escala de prote ção vai indicar o remanejamento de recursos entre os diversos setores. Os recursos se deslocariam de modo a expandir os setores relativamente mais protegidos, em detrimento dos mais desprotegidos.

(60) EVENSON e KISLEV (1973) discutem os pontos positivos e negativos do uso do número de artigos em revistas como un indicador da geração de tecnologia.

(61) Estudo usando o somatório dessas duas metodologias é yisto em HOMEM DE MELO (1981a). 
Para encontrar a estrutura de proteção, definimos pa ra cada atividade a proteção total dada pela soma das TPE durante os anos do período 1968/78, ou seja, a soja das áreas cheias das Figuras 1 e 2. O cálculo dessas äreas revelou a seguinte estrutura cres cente de proteção: milho, algodão, soja, feijão e arroz. De acordo com os conceitos teóricos expostos anteriormente, as atividades mais protegidas, como os cultivos de arroz e feijão, teriam recursos direcionados para si, o que se traduziria em aumento da área ocupada e, portanto, da produção e oferta internas. De outro modo, as ativi dades de milho, algodão e, em menor escala, a soja, perderiam recur sos para as demais atividades.

Apesar das Tarifas de Proteção Efetiva terem sido cal culadas para São Paulo, as comparações quanto aos resultados de pro dução e ärea cultivada foram feitas para o Brasil. Isto se deu, por que se espera que a escala de Proteção Efetiva encontrada para São Paulo rão se diferencie significativamente das outras regiões do País. Além disso, uma comparação apenas com os resultados de produção do Estado de São Paulo não captaria a influência exercida por ou tras regiões na oferta e demanda internas e, portanto, nos preços. Uma qualificação importante deve ser feita ao anali sar o deslocamento de recursos. Ela se refere à natureza estática da TPE, pois elas são calculadas para determinado instante no tempo. Isto implica que, para cada ano se tem uma certa escala de proteção. Apesar disso, o pađrão apresentado pela ordenação, com base na soma 
das äreas das Figuras 1 e 2, se manteve quando analisados os anos se paradamente.

Ao se confrontar as previsões da teoria com as taxas de crescimento da produção (Tabela 21), e com o crescimento da área cultivada (Tabela 20), os resultados parecem menos satisfatórios. As duas culturas com as menores proteções efetivas, algodão e milho, apresentaram resultados diversos quanto ao crescimento da produção e ao aumento da área cultivada. 0 algodão, que ocupava uma área de $3.938,9 \mathrm{mil}$ ha no triênio $67 / 69$, passa para 3.674,2 mil ha em 79/80. O milho, que possuia $9.507,6 \mathrm{mil}$ ha em $67 / 69$, cresce para $11.482,8 \mathrm{mil}$ ha em $79 / 80$. Quanto à taxa de cres cimento da produção brasileira, os resultados seguem a mesma direção. Assim, para o algodão, para os períodos 67/76 e 70/79, essas taxas foram de $-1,99$ (a) e $-4,41$, respectivamente. 0 milho, por sua vez, apresentou taxas positivas, ou seja, 3,55 no período 67 / 76 e 1,75 (a) em 70/79. 0 milho, portanto, não refletiu a previ são teórica, porque combinou desproteção com entrada de recursos. Isto, entretanto, não pode ser dito em relação aos de mais produtos de mercado interno, arroz e feijão, que apresentaram as maiores TPE totais. Para o arroz, as TPE foram positivas durante todos os anos e houve aumento de recursos para esta atividade. A àrea do triênio 67/69, de 4.456,9. mil ha, cresce para 5.835,9 mil ha em 79/80. O mesmo acontece com as taxas de crescimento da produção, 2,47 em 67/76 e 1,46 (a) em 70/79. 
o feijão, a segunda cultura na escala de proteção, apresentou acréscimos na área cultivada, passando de 3.649,0 mil ha em 67/69, para 4.479,9 $\mathrm{mil}$ ha em 79/80. As taxas negativas paracres cimento da produção, -1,83 em $67 / 76$ e -1,90 em 70/79, podem ser explicadas pelo acentuado decréscimo na produtividade da cultura, que era de $704 \mathrm{~kg} / \mathrm{ha}$ em $67 / 69$ e passa para $484 \mathrm{~kg} / \mathrm{ha}$ em 79/80.

Portanto, arroz e feijão confirmaram as expectativas teóricas e associaram escala de proteção efetiva positiva com entra da de recursos. Sem dúvida, o maior contraste nos resultados se encontra na soja, porque mesmo intermediária na escala de proteção, apresentou os maiores aumentos, tanto na ärea cultivada (de 746,7 mil ha em 67/69. para $8.548,2 \mathrm{mil}$ ha em 79/80), como na produção (ta xas de crescimento de 35,03 e 22,42, respectivamente, nos períodos $1967 / 76$ e 1970/79).

As verificações empíricas satisfizeram, em parte, as assertivas da teoria. Dos cinco produtos estudados, trếs deles (arroz, feijão e algodão) associaram a escala de proteção efetiva com atração ou saída de recursos. O grande crescimento da soja, esta principalmente, porque associou uma TPE negativa com a maior expansão de ärea e produção, e o aumento significativo da cultura do miTho, foram contra as previsões teóricas. 
Tabela 20 - Ārea cultivada e produtivade. Médias trienais. 1967/691979/80. Brasil.

\begin{tabular}{lrrrrr}
\hline PERIODO & ALGODÃO & ARROZ & FEIJÃO & MILHO & \multicolumn{1}{c}{ SOJA } \\
\hline & \multicolumn{5}{c}{ Area cultivada $(1.000 \mathrm{ha})$} \\
$1967 / 69$ & $3.938,9$ & $4.456,9$ & $3.649,0$ & $9.507,6$ & 746,7 \\
$1970 / 72$ & $4.438,9$ & $4.854,8$ & $3.788,7$ & $10.315,8$ & $1.742,2$ \\
$1973 / 75$ & $4.283,4$ & $4.921,9$ & $4.083,0$ & $10.478,4$ & $4.861,0$ \\
$1976 / 78$ & $3.809,5$ & $6.066,5$ & $4.400,9$ & $11.332,8$ & $7.088,6$ \\
$1979 / 80$ & $3.674,2$ & $5.835,9$ & $4.479,9$ & $11.482,8$ & $8.548,2$ \\
& \multicolumn{5}{c}{ Produtividade (kg/ha) } \\
$1967 / 69$ & 491 & 1.484 & 704 & 1.344 & 1.083 \\
$1970 / 72$ & 506 & 1.509 & 667 & 1.397 & 1.303 \\
$1973 / 75$ & 462 & 1.470 & 602 & 1.489 & 1.562 \\
$1976 / 78$ & 413 & 1.425 & 478 & 1.486 & 1.565 \\
$1979 / 80$ & 463 & 1.489 & 484 & 1.592 & 1.469 \\
\hline
\end{tabular}

FONTE: HOMEM DE MILO (1981a).

Tabela 21 - Taxa de crescimento da produção agricola brasileira. Cin co produtos. 1967/76 e 1970/79.

\begin{tabular}{|c|c|c|}
\hline PRODUTO & $1967 / 76$ & $1970 / 79$ \\
\hline Arroz & 2,47 & $1,46^{(a)}$ \\
\hline Feijão & $-1,93$ & $-1,90$ \\
\hline Milho & 3,55 & $1,75^{(\mathrm{a})}$ \\
\hline Soja & 35,03 & 22,47 \\
\hline Algodão & $-1,99^{(a)}$ & $-4,41$ \\
\hline
\end{tabular}

FONTE: HOMEM DE MELO (1981a)

(a) A letra a denota näo significativamente diferente de zero ao nr vel de $5 \%$. 
As limitações quanto ao nümero de culturas analisadas e ao pequeno período de estudo, não permitem avançar muito nas questões relativas à redistribuição da produção ao longo do tempo. Nas culturas aqui incluídas, mesmo que importantes em termos de ärea e renda do setor, não se consideraram produtos como café, cana-de-açúcar, laranja e atividades de pecuária de corte e leite.

E importante lembrar que a Taxa de Proteção Efetiva não é suficiente para indicar a lucratividade de uma cultura. A lucratividade entre atividades é um fator importante no direcionamento de recursos entre culturas, haja vista a mobilidade dos fatores dentro do setor agrícola. (62)

Ademais, no médio e no longo prazo, as alterações na composição da produção agrícola sofrem influências de uma série de instrumentos de política, como o crédito rural e os programas especiais, além das mudanças no nível tecnológico de cada atividade que afetam a taxa de retorno no cultivo dos diversos produtos.

Hä estudos que relacionam a geração desequilibrada de tecnologias e as mudanças na composição da produção (63). A hipótese se fundamenta em que "a natureza desequilibrada dos processos de ino

(62) Esta mobilidade é grande entre as culturas anuais, dentro das Iimitações impostas pelas condições ecolögicas. Para as culturas perenes e atividades pecuárías, espera-se que esta mobilidade seja menor.

(63) HOMEM DE MELO (1981a). 
vações técnicas entre produtos deve provocar, dependendo de sua intensidade ao longo do tempo, alterações na composição da produção agrícola".

A natureza das políticas econômicas que taxaram o se tor funcionaram mais homogeneamente entre produtos ${ }^{(64)}$, ou seja, ti nha uma direção no agregado do setor agrícola, enquanto o papel da tecnologia seria como elemento de compensação, como redutor dos cus tos, aumentando a produtividade e rentabilidade e atraindo recursos.

\section{4 - Disponibilidade de Tecnologias por Produto para São Paulo}

o período curto de anālise desta pesquisa limita, de certa forma, uma correlação maior dos argumentos de taxação da agri cultura com as inovações técnicas. O tempo requerido para geração e difusão de uma mudança tecnológica è de médio a longo prazo.

$$
\text { A seguir será vista a geração de tecnologias, tanto }
$$

no passado como em períodos recentes, e sua influência na produtivi dade e modernização de cada cultura, quando então se fará algumas confrontações com as políticas comerciais.

As evidências quantitativas do esforço de pesquisa es tão retratadas nas Tabelas 22 e 23. A Tabela 22 mostra a distribuição por produto das publicações de pesquisa do Instituto Agronômi-

(64) Refiro-me ao controle de preços, sobrevalorização cambial, quo tas e restrição de exportações; não em relação aos instrumen= tos de política agrícola, como crédito rural, preços mínimos en tre outros. 
co de Campinas (Revista Bragantia) no período 1941/74. Fazendo uma classificação baseada nos totais por produto, tem-se a seguinte ordenação decrescente: feijão, algodão, milho, soja e arroz.

Tabela 22 - Distribuição por produto das publicações de pesquisa do Instituto Agronômico de Campinas (Revista Bragantia, $1941 / 74)$.

\begin{tabular}{cccccc}
\hline PERIODO & ALGODÃO & ARROZ & FEIJÃO & MILHO & SOJA \\
\hline $1941 / 44$ & 3 & 2 & - & 1 & - \\
$1945 / 48$ & - & 1 & - & 3 & - \\
$1949 / 52$ & 1 & 2 & - & 6 & 2 \\
$1953 / 56$ & 9 & - & - & 9 & 6 \\
$1957 / 60$ & 16 & - & 5 & 11 & 4 \\
$1961 / 64$ & 11 & 6 & 9 & 18 & 4 \\
$1965 / 68$ & 12 & 5 & 32 & 7 & 6 \\
$1969 / 72$ & 11 & 10 & 14 & 7 & 6 \\
$1973 / 74$ & 3 & 2 & 8 & 3 & 4 \\
\hline TOTAL & 66 & 28 & 68 & 65 & 32 \\
\hline
\end{tabular}

FONTE: HOMEM DE MELO (1980). Disponibilidade de Tecnologia entre Pro dutos da Agricultura Brasileira.

Un ponto importante a ser enfatizado diz respeito à distribuição do número de publicações ao longo do tempo. Os produtos algodão, milho e soja tiveram uma distribuição de certa forma homogênea durante o período do estudo. Feijão, por sua vez, teve suas publicações concentradas a partir de 1965, isto é, em perĩodos 
mais recentes, sendo que atinge um pico no final da década de 60 e depois decresce. O arroz também teve suas pesquisas concentradas re centemente, pois o maior nümero de artigos se encontra no iníciodos anos setenta.

Apesar da ordenação feita acima, pode-se dizer que mi 1ho, algodão e feijão estão em um mesmo nível no nümero de publicações, enquanto soja e arroz se apresentam num nível inferior.

Outro estudo com esta mesma metodologia englobou um nümero maior de revistas ${ }^{(65)}$ e confirmou algumas configuraçöes acima descritas. A Tabela 23, retirada deste estudo, mostra que os pro dutos menos pesquisados foram a soja e o arroz. Por outro lado, a superioridade do algodão e, em menor proporção, o milho, fica evidente. O feijão, que antes ocupava a primeira posição, aqui fica nu ma situação intermediária.

Tabela 23 - Nümero de artigos científicos em pesquisa agrícola publicados em São Paulo, segundo o produto, 1927-77.

\begin{tabular}{cccccc}
\hline PERIODO & ALGODÃO & ARROZ & FEIJÃO & MILHO & SOJA \\
\hline $1927 / 29$ & 12 & 1 & - & 1 & 1 \\
$1930 / 39$ & 50 & 4 & - & 24 & 5 \\
$1940 / 49$ & 24 & 9 & 8 & 17 & 1 \\
$1950 / 59$ & 48 & 9 & 3 & 40 & 10 \\
$1960 / 69$ & 104 & 32 & 64 & 60 & 13 \\
$1970 / 77$ & 48 & 31 & 34 & 26 & 22 \\
\hline TOTAL & 286 & 86 & 109 & 168 & 52 \\
\hline
\end{tabular}

FONTE: SILVA, FONSECA E MARTIN (1979).

(65) SILVA, FONSECA e MARTIN (1979). Além da Revista Bragantia, se pesquisou o Boletim da Agricultura, Anais da ESALQ, Arquivos do Instituto Biológico, O Biológico, Revista da Agricultura, Bole tim Técnico do Instituto Agronômico e Boletins do Instituto dé Pesquisas IRI. 
Nota-se, como antes, que produtos como o arroz, feijão e soja ganham importância nas publicações, a começar da década de sessenta, enquanto milho e algodão mostraram uma participação mais uniforme durante as décadas.

E interessante salientar o esforço de pesquisa por grupos de assunto, como mostra HOMEM DE MELO (1980). Esse autor clas sificou as publicações em três grupos, sendo postulado que a concen tração diferencial entre grupos por produto geraria impactos diferentes no nível de produtividade das culturas. No primeiro grupo es tão as publicações em áreas básicas e entendidas como podendo condu zir a desenvolvimento significativos, principalmente em novas yarie dades. O segundo grupo ẻ encarado como pesquisas de manutenção, fun cionando como mantenedoras dos níveis de produtividade pela proteção dos ataques biológicos. No último grupo se encontram os estudos em äreas menos básicas, dos quais se espera uma contribuição menor na alteração dos nîveis de produtividade. (66)

A concentração de pesquisa para todos os produtos aqui estudados esteve nas āreas não bäsicas, sendo que as porcentagens são elevadas para todos eles ${ }^{(67)}$. Na anālise qualitativa adian te, se verā que, soja, algodão e milho tiveram uma compensação para esta pouca concentração em áreas básicas, atravēs da introdução de

(66) Para uma especificação das pesquisas pertinentes a cada grupo ver HOMEM DE MELO (1980).

(67) Arroz 64\%, feijão $77 \%$, algodão $69 \%$, soja $83 \%$ e milho $86 \%$. 
novas variedades ou linhagens de outros países. Para o arroz e ofei jão, os trabalhos nas áreas básicas, ao contrário, estiveram dependentes do esforço interno de pesquisa.

Deve-se dizer, ainda, que até 1974 poucos esforços de pesquisa no segundo grupo (ligado principalmente ao controle de pragas e doenças) foram efetuados para milho, soja e arroz, enquanto feijão e algodão tiveram mais estudos nesta ärea. Além disso, aquele trabalho mostra contemplação majoritária do milho nos estudos do terceiro grupo, voltados principalmente para pesquisas das práti cas culturais. Nestes dois pontos se voltará quando da análise qualitativa a seguir, onde eles serão questionados.

As discussões e evidências apontadas anteriormentevi saram quantificar os esforços de pesquisa agrícola diferenciados en tre os produtos arroz, feijão, algodão, milho e soja, que são objetos deste estudo. Resta dizer que aqueles trabalhos preocuparam com a quase totalidade dos produtos cultiyados pela agricultura paulista. Neste agregado de produtos, aqueles estudos procuram destacar o empenho diferenciado de pesquisa entre os produtos de mercado inter no e de exportação. Concluiram que estes ültimos foram os mais contemplados, visto que café, algodão, citros e cana-de-açūcar foramos mais pesquisados entre 1927-77.

A seguir se fará uma anālise qualitativa da geração de inovações para as cinco culturas em questão, com base em trabaThos de revisão histórica das pesquisas efetuadas. 
100.

\section{4 .1 - Algodão}

A história da pesquisa agrỉcola do algodão tem seu marco inicial efetivo com o começo dos trabalhos de melhoramento ge nético no Instituto Agronômico de Campinas em 1924. No começo dos anos 30 já havia resultados disponíveis para os agricultores na for ma de novas variedades que foram introduzidas. Na Tabela 24 se percebe que o processo de geração de novas variedades foi um esforço continuo ${ }^{(68)}$ durante todo o período, e visava responder aos problemas de pragas (principalmente percevejo a partir de 1938) e doenças (murcha por fusarizum em meados de 1957). Segundo AYER e SCHUH (1974), a melhoria obtida com as variedades resistentes à murcha foi de gran de magnitude. Essas variedades foram lançadas no início dos anos 60 com aumentos de rendimentos de aproximadamente $200 \%$ em relação às existentes no período anterior a 1930, quando atacados pela doença. o aumento porcentual de fibra para estas variedades em relação àque las foi superior a $20 \%$, e para o comprimento da fibra em torno de $30 \%$.

Após a segunda metade dos anos sessenta e até o final da década dos setenta, os esforços continuaram, assím como os resultados em termos de aumento de produtividade e caracteristicas das fibras (69).

(68) Como mostra a Tabela 24, de 1938 a 1956 (18 anos) foram lançadas apenas duas variedades. Segundo HONEM DE MELO (1981) há, neste período, uma clara descontinuidade no processo de inovações tecnológicas para o algodão em São Paulo.

(69) Veja FREIRE, MOREIRA e MEDEIROS (1980), Figuras 1 e 2. 
Tabela 24 - Variedades de algodão lançadas pelo IAC, suas origens e ëpocas.

\begin{tabular}{|c|c|c|c|c|}
\hline POSIÇÃO & CRONOLOGIA & & DENOMINACẼO & ORIGEM \\
\hline 19 & 1932 & IAC & 7387 & Express \\
\hline 29 & 1932 & IA $T$ & 7470 & Express \\
\hline 30 & 1934 & IA & 045 & Texas Bigboll \\
\hline 49 & 1934 & IA & 028 & Texas Bigboll \\
\hline 50 & 1936 & IA 1 & Piratininga 086 & Texas Bigboll \\
\hline 69 & 1938 & IA 2 & 21077 & IA 7470 \\
\hline 70 & 1945 & IA & Campinas 817 & Stoneville. 2B \\
\hline 89 & 1956 & IAC & 8 & Stoneville.2B \\
\hline 90 & 1958 & IAC & 9 & IA Campinas x Delfos \\
\hline 109 & 1957 & IAC & 10 & Deltapineland . 12 \\
\hline 119 & 1956 & IAC & 11 & IA. 7387 \\
\hline $12 ?$ & 1960 & $\mathrm{RM}$ & & Auburn $\cdot 56$ \\
\hline 139 & 1961 & $\mathrm{RM}$ & 2 & Rex Cotton \\
\hline 149 & 1961 & IAC & 12 & IA Campinas $x$ Delfos \\
\hline 159 & 1964 & IAC & RM 4 & Auburn 56 \\
\hline $16 ?$ & 1965 & IAC & 12.1 & IAC .12 \\
\hline 179 & 1966 & IAC & 12.2 & IAC $\cdot 12$ \\
\hline 189 & 1968 & IAC & $13 \cdot 1$ & Acala 5675 \\
\hline 199 & 1963 & IAC & RM 3 & Auburn $\cdot 56$ \\
\hline 209 & 1969 & IAC & RM $3 \cdot \operatorname{SM} 4$ & $\mathrm{IAC} \cdot \mathrm{RM} 3$ \\
\hline 219 & 1974 & IAC & 16 & $I A C=R M 4$ \\
\hline 229 & 1975 & IAC & 17 & IAC $\cdot R M 3$ \\
\hline 239 & 1979 & IAC & 18 & Acala 5675 x Mu 16 \\
\hline
\end{tabular}

FONTE: FREIRE, MOREIRA E MEDEIROS (1980). 
E importante salientar, no caso do algodão, o aproveitamento de material genético importado na obtenção ce variedades adaptadas. Na Tabela 24 observa-se que as origens das varjedades en volveran, na maioria, material estrangeiro. Este fato contribuiu pa ra uma redução dos custos da pesquisa, assim como para diminuição do tempo para obter os resultados. (70)

Quanto às causas do sucesso da modernização da lavou ra algodoeira em São Paulo, PASTORE, DIAS e CASTRO (1977) salientam que esta cultura sofreu uma concentração regional da ârea cultivada, representando um processo de busca de regiöes agronomicamente mais aptas. Essa concentraçăo geogxấfica foi fortemente marcada pela bus ca de adaptação regional de variedades, pela maior interação entre pesquisadores e produtores, e pela constituição de influentes grupos de interesse. Em adição, a exposição aos fatores do mercado internacional, pela possibilidade de exportação e as características de matéria-prima industrial, conseguiram estabelecer discriminações nos diferenciais de preço segundo certas qualidades do produto. Esses fatores possibilitaram internalizaçäo, pelos produtores, dos ga nhos advindos de uma maior produtividade e certas propriedades do produto como resultado do processo de inovação.

Esta cultura é um exemplo do estorço e sucesso conti nuos da pesquisa agrícola, quer seja para resolver problemas fitossanitários específicos, como para melhorar a qualidade do produto e produtividade da cultura.

(7,0) HOMEM DE MELO (1981a). 
103.

\section{$5.4 .2-$ Soja}

O programa de melhoramento da soja teve seu início em 1939 no Instituto Agronômico de Campinas, e se concentrou na importação de variedades e linhagens americanas e suas adaptações para as condições brasileiras.

Nos periodos de mais intensa implantação da cultura, que datam da segunda metade dos anos sessenta e início dos setenta, as variedades Santa Rosa e Hardee foram as principais introduzidas, frutos dos trabalhos do IAC. A variedade Santa Rosa, apesar de ter sua multiplicação comercial no Rio Grande do Sul a partir de 1963, corresponde à linhagem L-326, selecionada por aquele instituto em 1958.

Observa-se na Tabela 25 a evolução das introduções dos principais cultivares. Aqui também se nota, como no exemplo do algodão, a importância da importação de conhecimentos através da in trodução de germoplasmas estrangeiros. Atualmente, dos 48 cultivares recomendados, 26 são oriundos de programas nacionais de melhoramento (hibridações), enquanto 22 foram introduzidos dos EUA, meta de dos quais na forma de linhagens (KASTER e BONATO, 1980). E notório o grande esforço de pesquisa em tempos recentes, haja vista que, somente no ano de 1980, foram lançadas 16 novas cultivares. 
104.

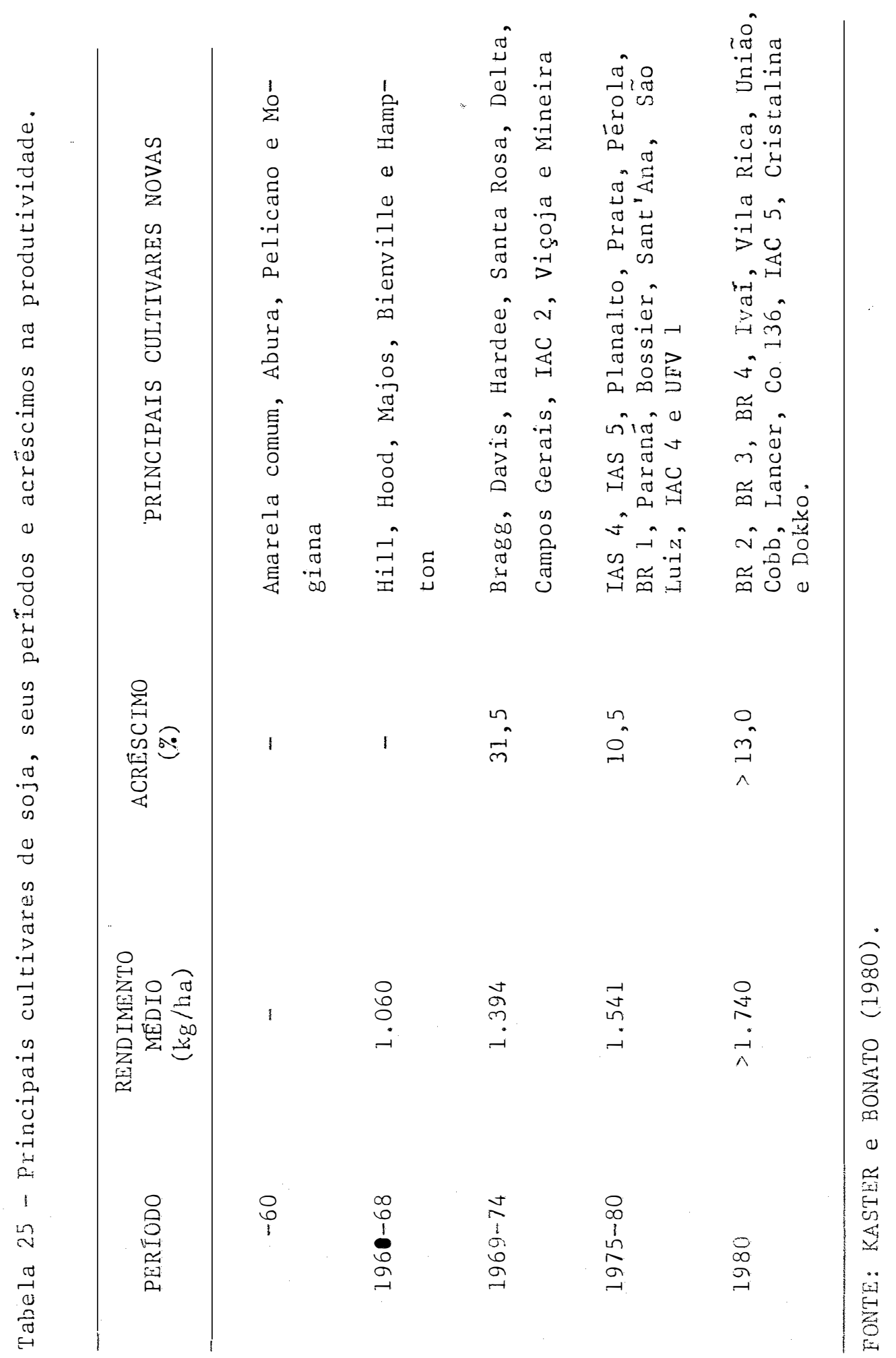


A Tabela 25 também retrata a evolução da produtivida de da cultura e sua correlação com o surgimento de novas cultivares. Naturalmente, esse progresso de produtividade não pode ser creditado somente à melhoria genética do material cultivado, mas, também, a fatores ligados ao manejo da cultura e do solo. Neste aspecto, a Tabela 26 salienta que nos ültimos dez anos aproximadamente $22 \%$ do aumento da produtividade pôde ser obtido com avanços no manejo do solo e da cultura. (71)

Tabela 26 - Ganhos médios de produtividade de três cultivares de so ja, devido ao uso de tecnologias mais avançadas no mane jo do solo e da cultura, a partir de experimentos em Pas so Fundo, RS.

\begin{tabular}{lccc}
\hline & \multicolumn{2}{c}{$\begin{array}{c}\text { RENDIMENTO MEDIO } \\
\text { CUltivg/ha })\end{array}$} & $\begin{array}{c}\text { GANHO } \\
(\%)\end{array}$ \\
\cline { 2 - 3 } & $1967 / 68 / 70$ & $1977 / 78 / 79$ & 30 \\
Bragg & 1.966 & 2.555 & 22 \\
Davis & 2.156 & 2.630 & 15 \\
Santa Rosa & 2.113 & 2.430 & 22 \\
\hline Média & 2.078 & 2.538 & 22 \\
\hline
\end{tabular}

FONTE: KASTER e BONATO (1980).

(71) Destes avanços, merecem destaque: a) tabelas de correção e fer tilização do solo; b) seleção de estirpes eficientes de $R h i z o=$ bizo; c) plantio direto; d) controle de ervas daninhas; e) épo ca de semeadura e população de plantas. 
De acordo com KASTER e BONATO, os desenvolvimentos tecnológicos da década de 70 possibilitaram que se reduzissem signi ficativamente os custos de produção. Nesta linha de pesquisa estão a maior racionalização no uso de insumos (principalmente no controle quimico de pragas e doenças e perdas na colheita, que permitem re dução de até $41 \%$ dos custos variáveis e de até $34 \%$ dos custos totais de produção). (72)

Para as perdas de colheita, estudos demonstraram que a regulagem adequada de máquinas na condução e na colheita da lavou ra possibilita reduzir o nível de perda em $50 \%$. No caso do uso de insumos, o controle de pragas com o manejo correto reduz sensivelmente o nümero de aplicações de praguicidas e o uso de variedades to lerantes dispensa qualquer produto químico para combater doenças.

As qualificações feitas acima nos levam a reconsiderar as evidências apontadas pela quantidade de artigos em revistas especializadas, que indicaram pequenos esforços na geração de inova ções para a soja. São notórios os sucessos alcançados pela pesquisa no aumento da produtividade da terra, ao lado de reduções de porte nos custos de produção que, conjuntamente, colaboraram para ascender a lucratividade desta lavoura.

(72) Referente à safra 1979/80, e para uma produtividade de 1.750 $\mathrm{kg} / \mathrm{ha}$. 


\subsection{3 - Mitho}

Este produto tem se caracterizado, no Estado de São Paulo, por um esforço considerável de pesquisa, tanto em termos de instituições, como de continuidade dos trabalhos. O histórico da pes quisa mostra um empenho que data do início deste século, com o desenvolvimento da primeira variedade melhorada, Assis Brasil, nome de seu criador. Houve constante intercâmbio, desde esta ëpoca, com instituições estrangeiras, o que contribuiu para entrada de germoplasmas novos. Foi, também, importante a então descoberta técnica do milho híbrido nos EUA, que impulsionou o melhoramento genético do milho.

Nas pesquisas brasileiras se destacaram tanto instituições püblicas como privadas. Nos anos 30 começaram os trabalhos no Instituto Agronômico de Campinas, na Escola Superior de Agricultura "Luiz de Queiroz", em Piracicaba, e na Escola Superior de Agri cultura do Estado de Minas Gerais, em Viçosa. Dentre as firmas particulares, se destaca a Sementes Agroceres S/A.

Os estudos na pesquisa do milho, concentrados princi palmente no campo da genética e melhoramento, tiveram resultados re levantes. Para se poder avaliar o potencial dos novos mate riais, alguns híbridos e variedades do IAC e ESALQ podem ser cita dos (73). Em 1946/47 foi obtido o híbrido H-3531, 22\% mais produtivo

(73) Dados baseados em GARCIA, RUAS e VENCOVSKY (1980). 
108.

que o cateto (cateto e cristal predominavam no início do século).Em 1953 foram lançados o híbrido $\mathrm{H}-4624$, 43\% mais produtivo que o Armour (desenvolvido em 1934 pelo IAC por cruzamentos de variedades na tivas e americanas) e a variedade Asteca, com mesmo potencial. No ano de 1956, o novo híbrido H-6999-A, que se mostrou 97\% superior à variedade Armour. Em 1963 foi obtido o Piramex, 9\% mais produtivo que o híbrido H-6999-A. Esses acrêscimos de produtividade são indicadores dos resultados das pesquisas, o que, de certa forma, está subestimado, pois não foi citada a participação das firmas privadas nacionais e estrangeiras que lançaram värios hỉbridos no mercado.

Além dessa linha de pesquisa visando o aumento da ca pacidade produtiva, estudos recentes de genêtica quantitativa têm sofisticado os trabalhos com vistas a incorporar qualidades específicas nas variedades atravês da introdução de genes. Assim, se destacam o Opaco $2\left(\mathrm{O}_{2}\right)$ (69\% mais lisina), o Ceroso (Wx) (mais amilopectina), o Sugary (SU) (rico em açūcares) e o Braquítico (br2) (re duz o tamanho da planta). Estão, também, avançados os estudos com citogenētica e fisiologia, conduzidos paralelamente com melhoristas, visando transferir resultados no lançamento de novas variedades.

Não obstante estes avanços genéticos da pesquisa do milho, algumas lacunas subsistem. GARCIA, RUAS e VENCOVSKY (1980) apontam os seguintes campos, ainda pouco explorados:

a) O controle de pragas é ainda pouco explorado pelos entomolo gistas. As medidas de controle existentes são de difícil adoção pe- 
109.

los agricultores. (74)

b) Controle de doenças é dificultado pela não ocorrência siste mática e pela baixa economicidade dos tratamentos.

c) As pesquisas nas äreas de colheita e armazenamento têm sido de pouca expressäo.

d) A parte relativa ao processamento industrial e à comerciali zação têm tido pouca atenção da pesquisa.

Ressaltam, além disso, que "o potencial de contribui ção das novas tecnologias poderia ser aumentado pela melhoria do ma nejo e práticas culturais, as quais não são muito aplicadas". Confirmando este aspecto, PASTORE, DIAS e CASTRO (1977) citam o milho como uma cultura "marginal", funcionando como atividade residual den tro das propriedades agrícolas em termos de utilização da terra, ca pital e recursos humanos, o que é causa para o pouco cuidado que se tem dado aos tratos culturais em geral.

Essa característica de cultura "residual" e as lacunas em algumas áreas de pesquisa têm representado um entrave para que a produtividade no Brasil alcance níveis mais expressivos. A pro dutividade em São Paulo, por exemplo, o Estado com maior produtividade, juntamente com Santa Catarina e Paranä, representa apenas $1 / 3$ daquela obtida nos países mais avançados, como os EUA.

(74) Há correspondência com o estudo de HOMEM DE MELO (1980), onde o nümero de publicações no segundo grupo, que incluia as pesquisas sobre pragas e doenças, representava menos de $5 \%$ do total de artigos para cultura. 
No tipo de análise feito por HOMEM DE MELO (1980), o

milho parece funcionar de maneira inversa, ou seja, com grandes avan ços nas āreas de pesquisas básicas, com resultados signíficativos para aumentar o potencial produtivo da espécie, mas com carência de estudos não básicos, com o propósito de resolver os problemas de cam po da cultura, o que vem limitando a produtividade e a lucratividade desta lavoura.

Como complemento a este raciocínio, vem a concepção de que a modernização de uma cultura é feita de maneira equilibrada; o plantio de uma variedade com maior potencial de produção se trans forma em maior produtividade quando se obedece às maiores exigências dessas variedades na forma de tratos culturais, como adubação, plantio, espaçamento, controle de pragas e doenças e cuidados na co 1heita, entre outros. Isto se refere ao que se chama de "pacote" tec nológico, que via de regra caracteriza a modernização de uma lavoura. (75)

(75) Pesquisas específicas, como incorporar resistência genética a doenças em certas variedades, de certo modo eliminam a prätica de tratamento contra essas doenças. No agregado, entretanto,es te fato não afeta a natureza da inovação em "pacote" do proces so de modernização agrícola. 


\subsection{4 - Arroz e feijão}

No exame das evidências quantitativas da geração de tecnologias medidas pelo número de publicações sobre as culturas em revistas especializadas, observa-se a carência de estudos para os produtos domésticos de consumo interno, dentre eles o arroz e o fei jão. A análise qualitativa, como se verā, não foge dessas evidências, senão tende a reafirmā-las.

A simples revisão do histórico da criação de novas variedades em São Paulo revela os parcos resultados obtidos na tentativa de criar inovações para o arroz. Os trabalhos iniciaram-se no IAC com os estudos de melhoramento, em 1937, quando apareceram os primeiros híbridos. Nesta época, destacou-se a variedade Pérola com resistência à seca e produtividade $25 \%$ superior à variedade Jaguari que, juntamente com a Cateto, eram as mais cultivadas. Foram lançados, depois, os IAC-25 e IAC-47 para culturas de sequeiro. Quanto à introdução de variedades importadas, foi tentado um material do IRRI (Filipinas). Assim, as IR-665, IR-85I e IR-890, todas para culturas irrigadas, chegaram a ser testadas por alguns agricultores. Essas va riedades se destacavam pela alta produtividade e grande resposta à adubação. Entretanto, tinham baixa resistência a bruzone, apresenta vam um tipo de arroz inferior e eram pilosas, o que causava dificul dades na colheita. Estes fatores impossibilitaram uma maior difusão dessas variedades. Em tempos recentes, o IAC selecionou as varieda- 
des IAC-1246 para sequeiro, e o IAC-120 e IAC-435, para irrigado.Além de São Paulo, devem ser citados os sucessos da pesquisa com arroz irrigado no Rio Grande do Sul pelo Instituto Riograndense do Ar roz (IRGA), mas com resultados para as características edafoclimäti cas da região.

E notörio, neste breve relato, que o nümero de novas variedades desenvolvidas para São Paulo e para a cultura de sequeiro, da qual se ocupa a grande maioria das lavouras (76), reflete o pequeno empenho da pesquisa do arroz. Este ponto parece importante, pois os jā irrisórios esforços de pesquisa tiveram que ser divididos entre as culturas de sequeiro e irrigado, sendo esta ūltima minoritária em termos de produção brasileira e paulista, principalmen te.

A pesquisa agrícola tem sido incapaz não só de criar novas variedades melhoradas como, tambêm, de desenvolver estudos nas áreas de tratos culturais e controle de pragas e doenças, importan tes para o incremento da produtividade ${ }^{(77)}$.

o arroz em São Paulo representa o exemplo de cultura em que os recursos dedicados à pesquisa foram poucos além de descon

(76) No Brasil, 70\% da produção total é origināria do sistema de se queiro. Em São Paulo, a região do Vale do Paraíba, responsáve $\bar{I}$ pela quase totalidade do cultivo irrigado, correspondeu a menos de $6 \%$ das sacas colhidas, no período $1970 / 1978$.

(77) A pequena resposta a fertilizantes nas variedades de sequeiro, o controle de ervas daninhas, como Arroz Vermelho e Arroz Preto, além dos problemas fitopatológicos como a Bruzone, Nematói des e Elasmo, são tópicos a serem melhor estudados. 
tínuos, com oscilações em suas provisões.

Quanto ao: feijão, sua problemātica em muito se apro-

xima do arroz. A Tabela 27 é explicativa quanto aos resultados da pesquisa com feijão, e se nota a pouca expressividade, principalmen te em São Paulo, e a dispersão dos resultados, assim como a falta de continuidade.

Apenas em períodos recentes, hä indícios do aumento dos esforços de pesquisa. Houve, a partir da segunda metade dos anos setenta, com a criação da EMBRAPA, uma maior coordenação das pesqui sas a nível federal. Na década dos setenta houve o surgimento de va riedades novas, não só em São Paulo como em outros Estados. Ademais, somente agora começa-se a dar atenção ao desenvolvimento de tecnolo gias para o sistema consorciado que representa mais de $90 \%$ da cultu ra de feijão no Brasil (78). Este parece ser um dos pontos importan tes na explicação da baixa produtividade alcançada por esta cultura tanto em São Paulo como no Brasil.

(78) Citado por BLUMENSCHEIN e GUAZZELLI (1980). 
114.

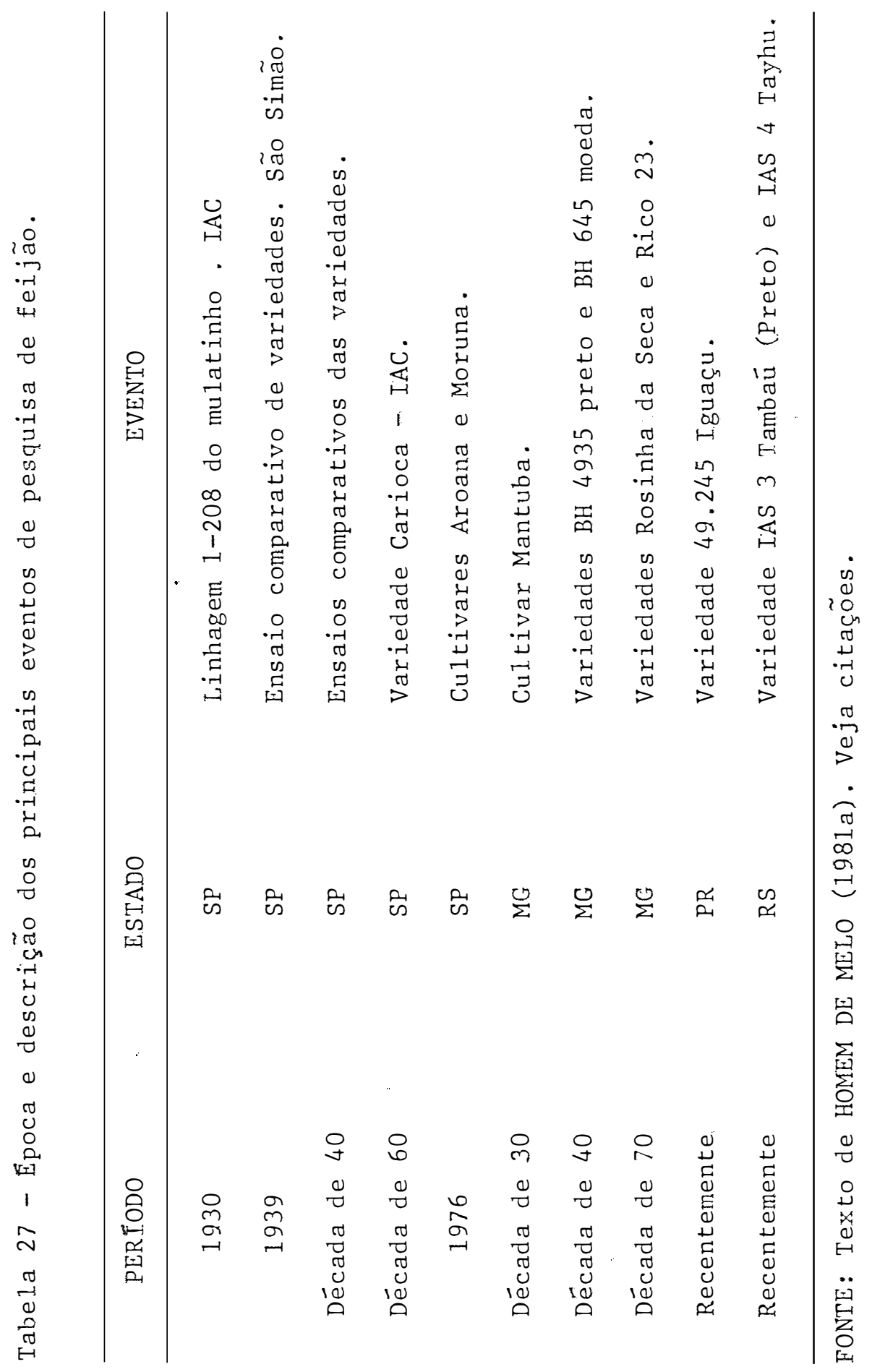




\section{5 - Proteção Efetiva e Tecnologia}

Pelo cômpuco das taxações inerentes à política comer cial por intermédio da Taxa de Proteção Efetiva, constataram-se as desproteções à soja, algodão e milho, principalmente. Foi revelado, também, uma desproteção menor para o feijão e uma proteção para o arroz, por todo o período. Não se deve esquecer, entretanto, que as conclusões acerca dessa escala de proteção tiveram ressalvas e quali ficações. No caso do arroz, especificamente, as interferências no co mércio entre países poderiam gerar taxas de proteção positivas, superestimando os resultados.

Pèla faceta da anālise de geração de tecnologias para estas mesmas culturas, tivemos um quadro geral bastante diverso. Produtos como soja e algodão foram beneficiados com uma geração de inovações técnicas, tanto no passado, como em épocas recentes das duas ūltimas décadas. Para o milho, as melhorias técnicas estiveram concentradas nas āreas de melhoramento genético, com falhas nas äreas não básicas. Além disso, o caráter de cultura marginal levanta do por alguns autores estaria limitando a adoção de novas tecnologias.

Os produtos de maior importância alimentar, por sua vez, tiveram um processo deficiente de geração de modernizações, principalmente no passado. Hä indícios que, em tempos recentes, o arroz e o feijão, principalmente este ūltimo, tiveram mais apoio de pesquisa. 
Milho e soja, principalmente esta, foram exemplos de correspondência entre desenvolvimentos tecnológicos, desproteção co mercial e resultados de produção e produtividade.

Ao milho se associaram a maior desproteção em termos de preço e desenvolvimentos tecnológicos significativos, com os tra balhos de melhoramento genético. Isto é retratado por uma produtivi dade crescente desde a segunda metade dos anos sessenta até o final da década de setenta. Assim, mesmo com TPE negativa, houve :aumento da ärea e da produtividade e, por conseguinte, crescimento da produ ção.

A soja, por seu turno, esteve entre as culturas com maiores progressos nas técnicas modernas. A importação de linhagens estrangeiras e suas adaptações às condições brasileiras, assim como os progressos obtidos nas āreas não básicas, permitiram um aumen to da produtividade, redução dos custos de produção e aumento da ren tabilidade da cultura ${ }^{(79)}$. Houve uma grande expansão da área cultivada com substancial entrada de recursos para esta lavoura.

Milho e soja são exemplos de associações entre os im pactos da política comercial, moderados pela introdução de novas tec nologias. Em períodos recentes, a soja, mesmo sofrendo algumas taxa ções comerciais, teve modernizações de vulto, repassadas para o aumento da lucratividade da cultura e que foram mais que suficientes

(79) Preços internacionais favoräveis foi fator importante para aumento da rentabilidade da cultura nos anos setenta. 
para superar os efeitos daquelas taxaçōes. Este processo se efetuou, em menor escala, para o milho, em vista da natureza desequilibrada das inovações daquela cultura e das razöes estruturais que caracterizañ seu cultivo. Mesmo assim, as modernizações nas āreas básicas funcionaram como moderadoras das diversas taxações comerciais e man tiveram crescentes a produção total e a área cultivada.

Quanto ao arroz, apresentou proteções efetivas positivas nos anos analisados e seu desempenho relativo ao crescimento da ärea e da produção foram satisfatórios. Por outro lado, a produtividade não se alterou durante o período 1967/80, ficando pröxima de $1.500 \mathrm{~kg} /$ ha. Como visto anteriormente, o arroz não recebeu inovações técnicas significativas no passado, e apenas no presente apresentou algum es-forço, mas que ainda não determinou um impacto sobre os sistemas de produção, principalmente o de sequeiro. O atraso tecnológico foi com pensado por proteções concedidas e a cultura sofreu impactos positivos. Entretanto, o caso do algodão, analisado a seguir, ressalta a importância dos demais instrumentos de politica agrícola, assim como a competição entre culturas na determinação daqueles impactos.

A cotonicultura apresentou evoluçốes tecnológicas dụ rante o passado e o presente, tanto por melhoramento genético de variedades, como por melhoria nos conhecimentos em āreas não básicas, o que explica grande parte do crescimento da produtividade observado atē hoje. 
Por outro lado, a Z̈rea ocupada pela cultura se reduziu deste 1967. Os efeitos das modernizaçes tecnológicas foram redu zidos pela competitividade frente a outras culturas e por taxações na política comercial. FREIRE, MOREIRA e MEDEIROS (1980) citam, confirmando estes pontos, vários fatores conjunturais: a) expansão da soja, que possuia maior rentabilidade pela redução dos seus custos de produção e preços favoräveis no mercado internacional (80); b) fixação de preços mínimos desvantajosos para o algodão; c) elevação dos custos de produção como consequência da participação crescente dos itens adubos, corretivos e defensivos (81).

Mesmo com desenvolvimentos tecnológicos, o algodäo não foi compensado dos efeitos negativos das políticas comerciais, além do que houve competição de outras atividades mais favorecidas. Por ūltimo, o feijã̃o parece ser um caso em que, em termos relativos, não foi dos produtos mais taxados. Na escala de proteção, o feijã̃o ocupou uma posição favorável, com taxas positivas em alguns anos, sendo superado em TPE total apenas pelo arroz. Quanto à tecnologia, apesar dos resultados esparsos, houve criação de algumas variedades em períodos recentes, além do que o cultivo em consörcio passou a contar com mais atenção das pesquisas. Grande par

(80) Não se deve esquecer a competitividade de outras culturas, como a cana-de-açūcar e laranja, ambas com lucratividade crescen te.

(81) Apêndice 1, Tabela 29, confirma este ponto. 
cela do cultivo do feijäo é feito em consorciamento, como atividade suplementar, o que proporciona custos de produção relativamente bai xos, apesar da baixa produtividade. 
6. CONCLUSÕES

Os estudos anteriores sobre a discriminação ou taxa ção do setor agrícola não levaram em conta todo o processo produtivo e consideraram somente os níveis nominais de proteção (preço do produto). A introdução do conceito de Proteção Efetiva na anālise desse problema esbarrou em algumas deficiências de dados e em certas particularidades da agricultura em relação às atividades industriais, e ajustes precisaram ser feitos.

Na determinação da TPE são considerados não somente os produtos, mas, também, os insumos necessários para sua produção. Neste particular, a abrangência da definição de taxação se amplia, porque 0 interrelacionamento entre agricultura e indústria é incorporado, e as políticas pertinentes a um setor podem ter seus efei tos medidos no outro setor. Um exemplo foi o processo de substitui 
ção de importações de insumos modernos, que trouxe os benefícios da industrialização, como as economias externas, empregos,entre outros, mas taxou os produtores na forma de preços mais elevados, uma vez que havia reserva de mercado.

Isso se agravou mais na medida em que o tripé de insumos modernos (defensivos, fertilizantes e tratores) passou a participar mais dos custos de produção, em vista de uma modernização do setor e dos aumentos de preços causados, principalmente, por forças de crises externas.

A própria taxação nominal, via preços dos produtos, foi o argumento maior da discriminação da agricultura. As taxas de proteção nominal (PN) se mostraram negativas para milho, soja, algo dão e para o feijão, na maioria dos anos. As taxas efetivas (TPE) reforçaram aquelas $\mathrm{PN}$ negativas e trouxeram um elemento a mais.

Entretanto, os resultados revelaram produtos do mercado domẻstico (arroz em todos os anos e feijão em 1973 e 1976) com tarifas nominais e efetivas positivas, indicando uma taxação do con sumidor e proteção aos produtores. A explicação para estas tarifas se fundamenta em imperfeições do mercado interno (economia fechada) e dos mercados externos (preços subsidiados), mas não retira a taxa ção implícita do consumidor, uma vez que a alternativa de aquisição a preços externos é, na prätica, viảvel.

Juntamente a isto, deve-se colocar a importância des ses produtos nos orçamentos e na nutrição das famílias de baixa ren da. 
Pelo lado da produção, os argumentos de proteção do setor que as taxas positivas poderiam gerar, não devem se separar das considerações sobre a participação desses produtos no total Ida ärea cultivada e no valor da produção. Em 1978 o milho e o feijão (com TPE negativas e, portanto, taxando o setor agrícola) ocuparam cerca de $70 \%$ da ārea cultivada e $41 \%$ do valor da produção dos prodü tos tidos como de consumo interno, em São Paulo.

As conclusões a respeito do grau das taxações, tanto dos consumidores quanto dos agricultores, precisam levar em conta, alëm dos valores da TPE em si, a importância relativa dos diversos produtos, tanto em termos de ārea colhida e valor da produção, como em termos orçamentārios e nutricionais.

No remanejamento de recursos entre atividades, as previsões teóricas da TPE foram confirmadas em parte pelos testes empíricos. Dos cinco produtos analisados, três associaram a escala de proteção efetiva com saîda/atração de recursos. As falhas de pre visão estariam ligadas, num primeiro estágio, ao número de produtos pesquisados. Alēm disso, não foi possível considerar demais setores, como a pecuária de corte e de leite.

As políticas compensatórias (crédito rural, pesqui sa, extensäo e subsídio a insumos), como argumento de balanceamento dos conceitos de taxação, esbarram nos efeitos de desdobramentos des sas próprias políticas. Neste particular, as características regio- 
nais, os produtos estudados, os custos, os efeitos distributivos e a duração de cada uma dessas políticas tornam a anālise mais ampla e difícil.

No que se refere à política de pesquisa agrícola, estes pontos parecem importantes. Dos produtos estudados, apenas so ja e algodão poderiam ser citados como atividades que contaram com - apoio contínuo de geração de inovações, tanto no passado quanto no presente. Arroz e feijão foram negligenciados na dotação de esforços para implementação de modernizações de seus cultivos. Apenas re centemente esta tendência se modificou, mas, ainda, sem impacto sig nificativo nos sistemas de produção mais representativos.

0 milho, apesar de contemplado com a criação de no vas variedades, apresenta-se como um produto com carência de pesqui sa em āreas não básicas. Além disso, a característica marginal de produção dentro das propriedades pode estar gerando situações que retardam a modernização desta lavoura.

Milho e soja foram exemplos de produtos em que as inovações técnicas ao longo do tempo retroagiram as taxações impostas pela política comercial, resultando em efeitos positivos nas per formances de produção e produtividade.

0 arroz, apesar de protegido comercialmente, não con tou com mudanças técnicas contínuas e significativas. Para este produto, os resultados brasileiros de produção e produtividade se mostraram positivos em períodos recentes. De modo conträrio, o algodão 
parece indicar um desvio nesta argumentação e, apesar de privilegia do em termos de melhorias tecnológicas em todas as äreas, elas não foram suficientes para superar os efeitos negativos das desproteções efetivas impostas ao longo do tempo pelas políticas comerciais. Os impactos negativos na produção se fizeram sentir, não obstante o al godão continuar competitivo e gerando divisas ao Brasil até o final do período estudado.

Neste sentido, parece justo afirmar o carāter asso ciativo dos instrumentos de política na determinação daqueles impac tos. Esta pesquisa não permite inferir o peso que cada instrumento teve nos resultados de cada produto. De maneira geral, as inovações tecnológicas e modernizações das atividades parecen condições neces sárias mas não suficientes para que se tenham impactos positivos nas diversas culturas.

Esta associação se fortalece na medida em que o vas. to leque de atividades, tanto de mercado interno como de exportação, que compõem o setor agrícola, faz com que a competição entre culturas seja um elemento importante na determinação desses impactos.

Este trabalho pretendeu quantificar as taxações impostas à agricultura pela política econômica engajada num processo de industrialização. A análise da taxação foi ampliada quando se in corporou a pesquisa agrícola como um fator de compensação. Entre tanto, as análises sobre a discriminação do setor agrícola devem ser ampliadas por outros estudos, onde se incorporem os efeitos de outros instrumentos de política. 
ALVES, E.L.G. e J.L.T. VIEIRA, 1978. Evolução do padrão alimentar da população da cidade de São Paulo. São Paulo, Fundação Instituto de Pesquisas Econômicas. [Seminário Economia da Tecnologia].

ANJOS, N.M. e J.F. NORONHA, 1974. Anālise dos mercados internacional e brasileiro de fertilizantes. Agricultura em São Paulo. São Pau$10,21(2): 1-23$.

ANJOS, N.M. e A.N. NETO, 1980. Subsídios aos preços de fertilizantes: custo social e benefícios. São Paulo. Secretaria da Agricultura, IEA. 8 p. (Relatório de Pesquisa no 12/80).

ASSOCIAÇÃO NACIONAL PARA A DIFUSÃO DA MECANIZAÇÃO AGRICOLA (ANAGRI), São Paulo, 1980. Características e qualidades técnicas da mecani zação agrícola no Brasil. Apresentado ao I Ciclo de Estudos sobre Mecanização Agrícola, Bauru, SP. 
AYER, H.W. e G.E. SCHUH, 1974. Taxas de retorno social e outros as pectos da pesquisa agrícola. O caso do algodão em São Paulo. Agricultura em São Paulo. São Paulo, 21(1): 1-29.

BALASSA, B., Coord., 1971. The Structure of Protection in Developing Countries. Baltimore. John Hopkins Press.

BARROS, J.R. Mendonça de; H.D. LOBATO; M.A. TROVOLO e M.H. ZOCKUN, 1975. Sistema fiscal e incentivos às exportações. Revista Brasileira de Economia. Rio de Janeiro, 29(4): 3-23.

BARROS, J.R. Mendonça de e D.H. GRAHAM, 1978. A Agricultura Brasileira e o Problema da Produção de Alimentos. São Paulo. IPE/USP. 38 p. Mimeografado.

BARROS, J.R.M.; M.A.S. FONSECA e M. BAUM, 1980. Perfil Técnico Econômico do Setor de Fertilizantes; fase I. 2. ed. São Paulo, Instituto de Pesquisas Tecnológicas (IPT), 81 p. (Publicações especiais).

BAUM, M., 1977. Uma nova fase na indústria de fertilizantes. São Paulo. FEA/USP. (Tese de Mestrado).

BERGSMAN, J. e A. CANDAU, 1969. Industrialization: past sucesses and future problems. In: ELLIS, H.S. ed. The Economy of Brazil. Berkeley, University of California Press.

BERGSHAN, J., 1970. Brazil: Industrialization and Trade Policies. London. Oxford University Press.

BERGSMAN, J., 1975. A política de comërcio exterior no Brasil. Estudos Econômicos. São Paulo, 5⑵: 51-104. 
BLUMENSCHEIN, A. e R.J. GUAZZELLI, 1980. A contribuição das Ciências Agrärias para o desenvolvimento agrícola do arroz e do feijão. Revista de Economia Rural. Brasília, 18(3): 435-446.

BOLETIM DE COMERCIO EXTERIOR, Brasilia, CACEX, 1969-1980.

COMISSÃO DE FINANCIAMENTO DA PRODUÇÃO, Brasília, 1973-1980. Anuārio. Estatístico.

COMISSÃO DE FINANCIAMENTO DA PRODUÇÃO, Brasília, 1975. Preços Mínimos, regiões Centro-Oeste, Sul e Sudeste, safra 75/76.

COMISSÃO DE FINANCIAMENTO DA PRODUÇÃO, Brasília, 1978. Relatório. Anual. $534 \mathrm{p}$.

CONJUNTURA ECONÔMICA, Rio de Janeiro, Fundação Getülio Vargas. 1968-1980 .

CORDEM, W.M., 1971. The Theory of Protection. London, Oxford University Press. 263 p.

CORDEM, W.M., 1934. Trade Policy and Economic Welfare. Oxford, Claredon Press.

CORDEM, W.M., 1979. A estrutura de um sistema tarifário e a taxa de proteção efetiva. In: SAVASINI, J.A.A.; P.S. MALAN e W. BAER, Coord. Economia Internacional. São Paulo, Edição Saraiva, p. $193-217$.

ESTADOS UNIDOS. Departament of Agriculture, 1970-1979. Agricultural. Statistics. 
EVENSON, R.E. e Y. KISLEV, 1973. Research and Productivity in wheat and Maize. Journal of Political Economy. Chicago, 81(6): 130929.

EVENSON, R.E., 1974. International Diffusion of Agrarian Technology. The Journal of Economic History. New York, 34(1): 51-73.

FREIRE, E.C.; J.A.N. MOREIRA e L.C. MEDEIROS, 1980. A contribuição das Ciências Agrárias para o desenvolvimento: 0 caso do algodão. Revista de Economia Rural. Brasília, 18(3): 383-413.

HOMEM DE MELO, F.B. e G.P. ZOCKUN, 1977. Exportações agrícolas, balanço de pagamentos e abastecimento do mercado interno. Estudos Econômicos. São Paulo, $\underline{7}(2):$ 9-50.

HOMEM DE MELO, F.B., 1978. Agricultura brasileira: incerteza e disponibilidade de tecnologia. São Paulo. FEA/USP. 142 p. (Tese de Livre-Docência).

HOMEM DE MELO, F.B., 1979. A política econômica e o setor agrícola no período pós-guerra. Revista Brasileira de Economia. Rio de Janeiro, 33(1): 25-63.

HOMEM DE MELO, F.B., 1980. Disponibilidade de tecnologia entre pro dutos da agricultura brasileira. São Paulo. IPE/USP. 48 p. (Tra balho para Discussão, 36).

HOMEM DE MELO, F.B., 1981. Política comercial, tecnologia e preços de alimentos no Brasil. Estudos Econômicos. São Paulo, 11(2): 123-142. 
HOMEM DE MELO, F.B., 1981a. O Problema Alimentar no Brasil: A Importância dos Desequilíbrios Tecnológicos. São Paulo. FIPE/USP. $362 \mathrm{p}$.

HOMEM DE MELO, F.B. e E.G. FONSECA, 1981. Prōalcool, Energia e Transportes. São Paulo. Pioneira FIPE, $163 \mathrm{p}$.

GARCIA, J.C.; D.G.G. RUAS e R. VENCOVSKY, 1980. A contribuição das Ciências Agrärias para o desenvolvimento do milho e do sorgo. Revista de Economia Rural. Brasília, 18(3): 475-493.

INFORMAÇÕES AGRICOLAS, São Paulo, Instituto de Economia Agrícola, 1971-1980.

JOHNSON, D.G., 1973. World Agriculture in Disarray. Londres, Fontana/Collins and Trade Policy Research Center. 304 p.

KASTER, M. e E.R. BONATO, 1980. Contribuição das Ciências Agrárias para o desenvolvimento: A pesquisa em soja. Revista de Economia Rura1. Brasília, 18(3): 415-434.

KNIGHT, P.T., 1971. Brazilian Agricultural Technology and Trade: A Study of Five Commodities. New York. Praeger Publishers. 223 p.

LEFF, N.H., 1969. The "Exportable Surlus" approach to foreing trade in underdeveloped countries. Economic Development and Cultural Change. Chicago, $17(3): 346-355$.

LEMGRUBER, A.C., 1976. O sistema cambial brasileiro a taxas flutuantes. Conjuntura Econômica. Rio de Janeiro, 30(5): 87-102. 
LOPES, M.R., 1979. Política Monetária e Crédito Rural. Revista de. Economia Rural. Brasília, $17(1)$ : 19-50.

LOPES, M.R. e G.E. SCHUH, 1979. A Mobilização de Recursos da Agricultura: Uma Anālise Política para o Brasil. Brasília, Comissão de Financiamento da Produção. 105 p. (Coleção Anālise e Pesquisa, 8).

MALAVOLTA, E. e J.P. ROMERO, Coord., 1975. Manual de Adubação. 2. ed. São Paulo, ANDA. 346 p.

MAtSunaGA, M.; P.F. BEmElmans; P.E.N. de TOLEdO; R.D. DULley; H. OKAWA e I.A. PEDROSO, 1976. Metodologia de custo de produção utilizada pelo IEA. Agricultura em São Paulo. São Paulo, 23(1): 123-139 .

NEUHAUS, P., 1977. Uma nota sobre o conceito de proteção efetiva. Revista Brasileira de Economia. Rio de Janeiro, 31 (3): 547-552.

OFFICER, L.H., 1976. The purchasing-power-parity theory of exchange rates: A review article. IMF Staff Papers, 23(1): 1-60.

PASTORE, J.; G.L.S. DIAS e M.C. CASTRO, 1976. Condicionantes da produtividade da pesquisa agrícola no Brasil. Estudos Econômicos. São Paulo, 6 (3): 147-182.

PASTORE, A.C., 1979. Exportações agrícolas e desenvolvimento econô mico. In: VEIGA, A., Coord. Ensaios Sobre Politica Agrícola Brasileira. São Paulo, Secretaria da Agricultura, p. 207-231.

PETERSON, W.L., 1979. International farm prices and the social cost of cheap food policies. American Journal of Agricultural Economics. Menasha, 61(1): 12-21. 
SCHUH, G.E., 1968. Effects of some general economic development. American Journal of Agricultural Economics. Menasha, 50(5): 1283-1293.

SCHUH, G.E., 1974. The exchange rate and U.S. agriculture. American Journal of Agricultural Economics. Menasha, 56(1): 1-13.

SILVA, G.S.P.; M.A. FONSECA e N.B. MARTIN, 1979. Os rumos da pesquisa agrícola e o problema da produção de alimentos. Algumas evidências no caso de São Paulo. São Paulo. Secretaria da Agri cultura, IEA. 25 p.

SILVA, G.L.P.S.; M.A.S. FONSECA e N.B. MARTIN, 1980. Investimento na geração e difusão de tecnologia agrïcola no Brasil. Revista de Economia Rural. Brasília, 18(2): 327-338.

STATE OF FOOD AND AGRICULTURE, Rome, FAO, 1979.

VALDES, A.E., 1973. Trade policy and its effect on external agricultural trade of Chile 1945-1965. American Journal of Agricultural Economics. Menasha, 55(2): 154-164.

VEIGA, A., 1974. The impact of trade policy on Brazilian Agriculture, 1947-1967. Lafayette, Indiana, Purdue University. 522 p. (Tese de $\mathrm{PhD}$ ).

VEIGA, A., 1979. A falsa dicotomia: exportação e abastecimento interno. Revista de Economia Rural. Brasilia, 17(1): 75-78.

VERA FILHO, F. e H. TOLLINI, 1979, Progresso tecnológico e desenvolvimento agrícola. In: VEIGA, A., Coord. Ensaios sobre Política Agrícola Brasileira. São Paulo, Secretaria de Agricultura, · p. $87-136$. 
132.

TRADE YEARBOOK. FAO, RoTRe, 1979.

ZOCKUN, M.H.G.P., Coord., 1976. A Agricultura e a Politica Comercial Brasileira. São Paulo. USP/IPE. 138 p. (Série Monografia, 8). 
133.

$A P E N D I C E S$ 
134.

APENDICE 1: Participação do tripē de insumos modernos (fertilizantes, defensivos e trator) no custo de produção das cuI turas de arroz, algodão, feijão, milho e soja.

As ponderações com respeito ao nível de tecnolo gia, sistemas de produção e as regiões (DIRAS) consideradas foram as mesmas efetuadas para o cálculo dos coeficientes técnicos (Tabe 1 as 28 a 32). Para maiores detalhes consultar os rodapés das referidas Tabelas. 
135.

Tabela 28 - Participação porcentual de fertilizantes, defensivos e trator de rodas no custo de produção de arroz. São Pau1o. $1970 / 71-1979 / 80$.

\begin{tabular}{ccccc}
\hline $\begin{array}{c}\text { ANO } \\
\text { AGRICOLA }\end{array}$ & $\begin{array}{c}\text { DEFENSIVOS } \\
\%\end{array}$ & $\begin{array}{c}\text { FERTILI- } \\
\text { ZANTES } \\
\%\end{array}$ & $\begin{array}{c}\text { TRATOR } \\
\text { DE RODA } \\
\%\end{array}$ & $\begin{array}{c}\text { TOTAL } \\
\%\end{array}$ \\
\hline $1970 / 71$ & 6,8 & 15,5 & - & 22,3 \\
$1971 / 72$ & 6,0 & 15,0 & - & 21,0 \\
$1972 / 73$ & 4,9 & 15,5 & - & 20,4 \\
$1973 / 74$ & 5,0 & 16,0 & - & 21,0 \\
$1974 / 75$ & 5,0 & 24,5 & 6,6 & 31,6 \\
$1975 / 76$ & N.E. & 25,0 & 14,0 & 35,1 \\
$1976 / 77$ & 1,9 & 19,2 & 17,9 & 45,2 \\
$1977 / 78$ & 1,5 & 25,8 & 16,8 & 43,2 \\
$1978 / 79$ & 1,3 & 25,1 & 29,4 & 44,9 \\
$1979 / 80$ & 5,4 & 10,1 & & \\
\hline
\end{tabular}

N.E.: Não Especificado. 1970/71 - 1975/76 - Custo efetivo. 1976/77 - 1979/80 - Custo total.

FONTE: Instituto de Economia Agrícola (IEA). 
136.

Tabela 29 - Participação de defensivos, fertilizantes e trator de ro das no custo de produção de algodão. São Paulo. 1970/71$-1979 / 80$.

\begin{tabular}{ccccc}
\hline $\begin{array}{c}\text { ANO } \\
\text { AGRICOLA }\end{array}$ & $\begin{array}{c}\text { DEFENSIVOS } \\
\%\end{array}$ & $\begin{array}{c}\text { FERTILI- } \\
\text { ZANTES } \\
\%\end{array}$ & $\begin{array}{c}\text { TRATOR } \\
\text { DE RODAS } \\
\%\end{array}$ & $\begin{array}{c}\text { TOTAL } \\
\%\end{array}$ \\
\hline $1970 / 71$ & 13,6 & 13,0 & 14,5 & 41,1 \\
$1971 / 72$ & 14,2 & 12,5 & 14,0 & 40,7 \\
$1972 / 73$ & 14,3 & 13,9 & 11,5 & 39,7 \\
$1973 / 74$ & 12,0 & 14,5 & 10,7 & 37,2 \\
$1974 / 75$ & 9,0 & 33,2 & 6,1 & 48,3 \\
$1975 / 76$ & 9,5 & 32,5 & 5,4 & 47,4 \\
$1976 / 77$ & 13,7 & 14,4 & 7,9 & 36,0 \\
$1977 / 78$ & 12,0 & 18,0 & 8,6 & 38,6 \\
$1978 / 79$ & 13,7 & 21,2 & 9,7 & 44,6 \\
$1979 / 80$ & 14,7 & 19,7 & 11,0 & 45,4 \\
\hline
\end{tabular}

1970/71 - 1975/76 - Custo efetivo. 1976/77 - 1979/80 - Custo total.

FONTE: Instituto de Economia Agrícola (IEA). 
137.

Tabela 30 - Participação de fertilizantes, defensivos e trator de ro das no custo de produção de feijão. São Paulo. 1970/71 $1979 / 80$.

\begin{tabular}{ccccc}
\hline $\begin{array}{c}\text { ANO } \\
\text { AGRICOIA }\end{array}$ & $\begin{array}{c}\text { DEFENSIVOS } \\
\%\end{array}$ & $\begin{array}{c}\text { FERTILI } \\
\text { ZANTES } \\
\%\end{array}$ & $\begin{array}{c}\text { TRATOR } \\
\text { DE RODAS } \\
\%\end{array}$ & $\begin{array}{c}\text { TOTAL } \\
\%\end{array}$ \\
\hline $1970 / 71$ & - & 20,4 & - & 20,4 \\
$1971 / 72$ & - & 19,4 & - & 19,4 \\
$1972 / 73$ & - & 34,6 & 8,6 & 43,2 \\
$1973 / 74$ & 2,0 & 28,0 & 6,5 & 36,5 \\
$1974 / 75$ & 1,6 & 42,6 & 4,5 & 48,7 \\
$1975 / 76$ & 4,5 & 26,5 & 13,8 & 44,8 \\
$1976 / 77$ & 4,1 & 10,8 & 14,4 & 29,3 \\
$1977 / 78$ & 3,6 & 14,4 & 18,8 & 36,8 \\
$1978 / 79$ & 10,8 & 17,4 & 15,7 & 43,9 \\
$1979 / 80$ & 10,7 & 18,3 & 17,8 & 46,8 \\
\hline
\end{tabular}

1970/71 - 1973/74 - Custo efetivo. 1974/75 - 1979/80 - Custo total.

FONTE: Instituto de Economia Agrícola (IEA). 
138.

Tabela 31 - Participação de defensivos, fertilizantes e trator de ro das no custo de produção de milho. São Paulo. 1970/71 - $1979 / 80$.

\begin{tabular}{ccccc}
\hline $\begin{array}{c}\text { ANO } \\
\text { AGRICOLA }\end{array}$ & $\begin{array}{c}\text { DEFENSIVOS } \\
\%\end{array}$ & $\begin{array}{c}\text { FERTILI- } \\
\text { ZANTES } \\
\%\end{array}$ & $\begin{array}{c}\text { TRATOR } \\
\text { DE RODAS } \\
\%\end{array}$ & $\begin{array}{c}\text { TOTAL } \\
\%\end{array}$ \\
\hline $1970 / 71$ & - & 28,0 & 19,5 & 47,5 \\
$1971 / 72$ & - & 25,4 & 23,4 & 48,8 \\
$1972 / 73$ & - & 30,0 & 18,4 & 48,4 \\
$1973 / 74$ & - & 39,9 & 12,4 & 52,3 \\
$1974 / 75$ & - & 39,9 & 12,4 & 52,3 \\
$1975 / 76$ & - & 39,9 & 12,4 & 52,3 \\
$1976 / 77$ & - & 20,8 & 22,7 & 43,5 \\
$1977 / 78$ & - & 28,5 & 28,5 & 57,0 \\
$1978 / 79$ & - & 28,3 & 26,4 & 54,7 \\
$1979 / 80$ & - & 28,2 & 30,8 & 59,0 \\
\hline
\end{tabular}

1970/71 - 1975/76 - Custo efetivo. 1976/77 - 1979/80 - Custo total.

FONTE: Instituto de Economia Agrícola (IEA). 
139.

\begin{tabular}{|c|c|c|c|c|}
\hline $\begin{array}{c}\text { ANO } \\
\text { AGRICOLA }\end{array}$ & $\begin{array}{c}\text { DEFENSIVOS } \\
\%\end{array}$ & $\begin{array}{c}\text { FERTILI- } \\
\text { ZANTES } \\
\%\end{array}$ & $\begin{array}{c}\text { TRATOR } \\
\text { DE RODAS } \\
\%\end{array}$ & $\begin{array}{c}\text { TOTAL } \\
\%\end{array}$ \\
\hline $1970 / 71$ & 3,8 & 19,7 & 19,0 & 42,5 \\
\hline $1971 / 72$ & 3,4 & 16,2 & 19,4 & 39,0 \\
\hline $1972 / 73$ & 2,9 & 20,0 & 16,2 & 39,1 \\
\hline $1973 / 74$ & 3,0 & 19,3 & 10,2 & 32,5 \\
\hline $1974 / 75$ & 6,0 & 28,5 & 10,4 & 44,9 \\
\hline $1975 / 76$ & 6,0 & 28,5 & 10,4 & 44,9 \\
\hline $1976 / 77$ & 14,3 & 17,6 & 10,8 & 42,7 \\
\hline $1977 / 78$ & 12,8 & 23,3 & 14,3 & 50,4 \\
\hline $1978 / 79$ & 12,5 & 26,0 & 14,7 & 53,2 \\
\hline $1979 / 80$ & 14,8 & 25,0 & 19,4 & 59,2 \\
\hline
\end{tabular}

1970/71 - 1974/75 - Custo efetivo.

1975/76 - 1979/80 - Custo total.

FONTE: Instituto de Economia Agrícola (IEA). 
140.

APENDICE 2: Custos de beneficiamento de arroz e algodão. 
141.

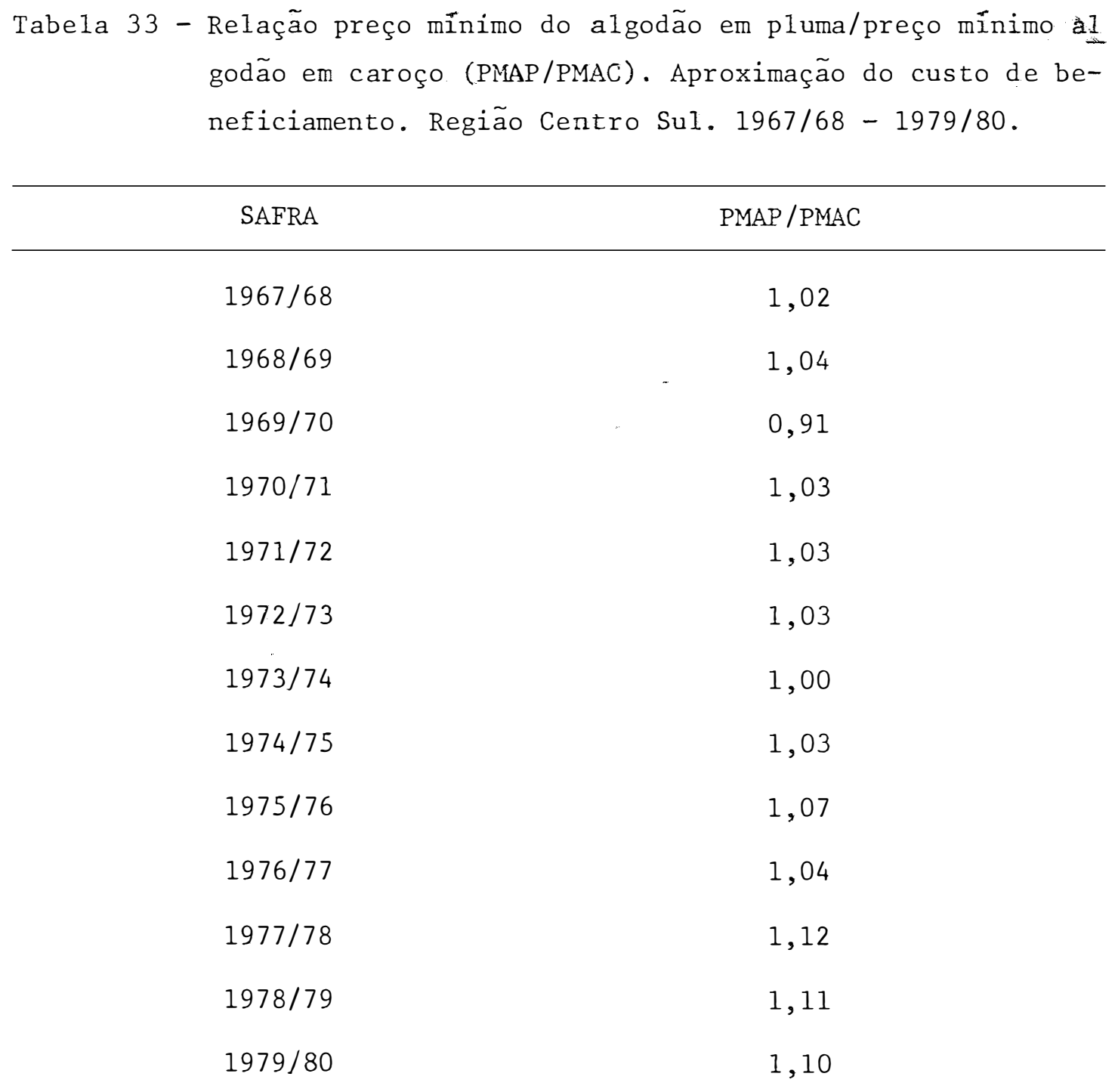

FONTE: Dados primários da Comissão de Financiamento da Produção (CFP). 
Tabela 34 - Custo de beneficiamento de arroz. Região Centro Sul. 1968-1980.

\begin{tabular}{|c|c|}
\hline ANO & Cr $\$ /$ TONELADA BENEFICIADA \\
\hline 1968 & 76,00 \\
\hline 1969 & 92,00 \\
\hline 1970 & 111,00 \\
\hline 1971 & 133,00 \\
\hline 1972 & 156,00 \\
\hline 1973 & 179,00 \\
\hline 1974 & 231,00 \\
\hline 1975 & 295,00 \\
\hline 1976 & 355,00 \\
\hline 1977 & 405,00 \\
\hline 1978 & 561,00 \\
\hline 1979 & 864,00 \\
\hline $1980^{-}$ & $1.730,00$ \\
\hline
\end{tabular}

FONTE: Comissão de Financiamento da Produção (CFP). Os valores acima foram obtidos deflacionando os dados de custo de beneficiamento de 1975 (1968 a 1974) e de 1977 (valores de 1978 a 1980). Utilizou-se como deflator o indice " 2 " da Conjuntura Econômica. 
143.

APENDICE 3: Dados complementares. 
Tabela 35 - Teor de nutrientes (N, $\mathrm{P}_{2} \mathrm{O}_{5}$ e $\mathrm{K}_{2} \mathrm{O}$ ) nos fertilizantes sul fato de amônio, superfosfato simples, superfosfato triplo e cloreto de potássio.

\begin{tabular}{|c|c|c|c|}
\hline & $\mathrm{P}_{2}{ }_{\%}^{0} 5$ & $\mathrm{~K}_{2} \mathrm{O}$ & $\begin{array}{l}N \\
\%\end{array}$ \\
\hline Sulfato de amōnio & - & - & - \\
\hline Superfosfato simples & $\begin{array}{c}19-21 \\
(20)\end{array}$ & - & - \\
\hline Superfosfato triplo & $\begin{array}{c}42-46 \\
(44)\end{array}$ & - & - \\
\hline Cloreto de potássio & - & $\begin{array}{c}60-62 \\
(61)\end{array}$ & - \\
\hline
\end{tabular}

FONTE: MALAVOITA e ROMERO; Coord. (1975). Manual de Adubação. Associação Nacional para Difusão de Adubos (ANDA). 
145.

Tabela 36 - Vendas de tratores de quatro rodas no Brasil, segundo a faixa de potência. 1970-1979.

\begin{tabular}{rccc}
\hline ANO & $\begin{array}{c}\text { Até } 51 \mathrm{HP} \\
\text { (Baixa Potência) }\end{array}$ & $\begin{array}{c}52 \mathrm{HP} \text { a } 70 \mathrm{HP} \\
\text { (Mêdia Potência) }\end{array}$ & $\begin{array}{c}\text { Acima de } 71 \mathrm{HP} \\
\text { (Alta Potência) }\end{array}$ \\
\hline 1970 & 4.732 & 6.588 & 2.247 \\
1971 & 6.888 & 10.712 & 3.845 \\
1972 & 9.343 & 13.041 & 5.755 \\
1973 & 6.635 & 16.595 & 12.769 \\
1974 & 7.321 & 20.449 & 13.662 \\
1975 & 6.832 & 25.865 & 21.010 \\
1976 & 5.683 & 28.287 & 24.402 \\
1977 & 3.855 & 20.676 & 17.335 \\
1978 & 2.892 & 16.782 & 20.762 \\
1979 & 2.433 & 22.753 & 25.250 \\
\hline
\end{tabular}

FONTE: Dados primärios da ANAGRI. Foram computadas as marcas CBT, Ford, Massey Ferguson e Valmet. 
146.

Tabela 37 - Participação porcentual dos Estados Unidos na importação de defensivos (toneladas e valor em dólares) pelo Brasil. 1968-1980.

\begin{tabular}{ccc}
\hline ANO & $\begin{array}{c}\text { PORCENTAGEM } \\
\text { (Toneladas) }\end{array}$ & $\begin{array}{c}\text { PORCENTAGEM } \\
\text { (Valor US } \$)\end{array}$ \\
\hline 1968 & 52,6 & 43,7 \\
1969 & 44,2 & 35,2 \\
1970 & 45,6 & 35,5 \\
1971 & 30,0 & 28,0 \\
1972 & 25,1 & 24,6 \\
1973 & 28,3 & 25,1 \\
1974 & 29,3 & 23,9 \\
1975 & 54,1 & 51,3 \\
1976 & 40,7 & 49,8 \\
1977 & 34,4 & 42,7 \\
1978 & 46,0 & 49,1 \\
1979 & 63,1 & 67,4 \\
1980 & 27,4 & 65,0 \\
\hline 1968 & 50,3 &
\end{tabular}

Nota: De 1968-1970, NBM 59240 e 59260. De 1971-1973, 38.11.02.00 e 38.11.03.00. 1974, 38.11.02.00 e 38.11.03.01. De 1975-1979, $38.11 .02 .00,38.11 .03 .01$ e 38.11.03.02. 1980, 38.11.02.01, $38.11 .02 .99,38.11 .03 .01$ e 38.11 .03 .02 .

FONTE: Boletim de Comércio Exterior - CACEX. 
147.

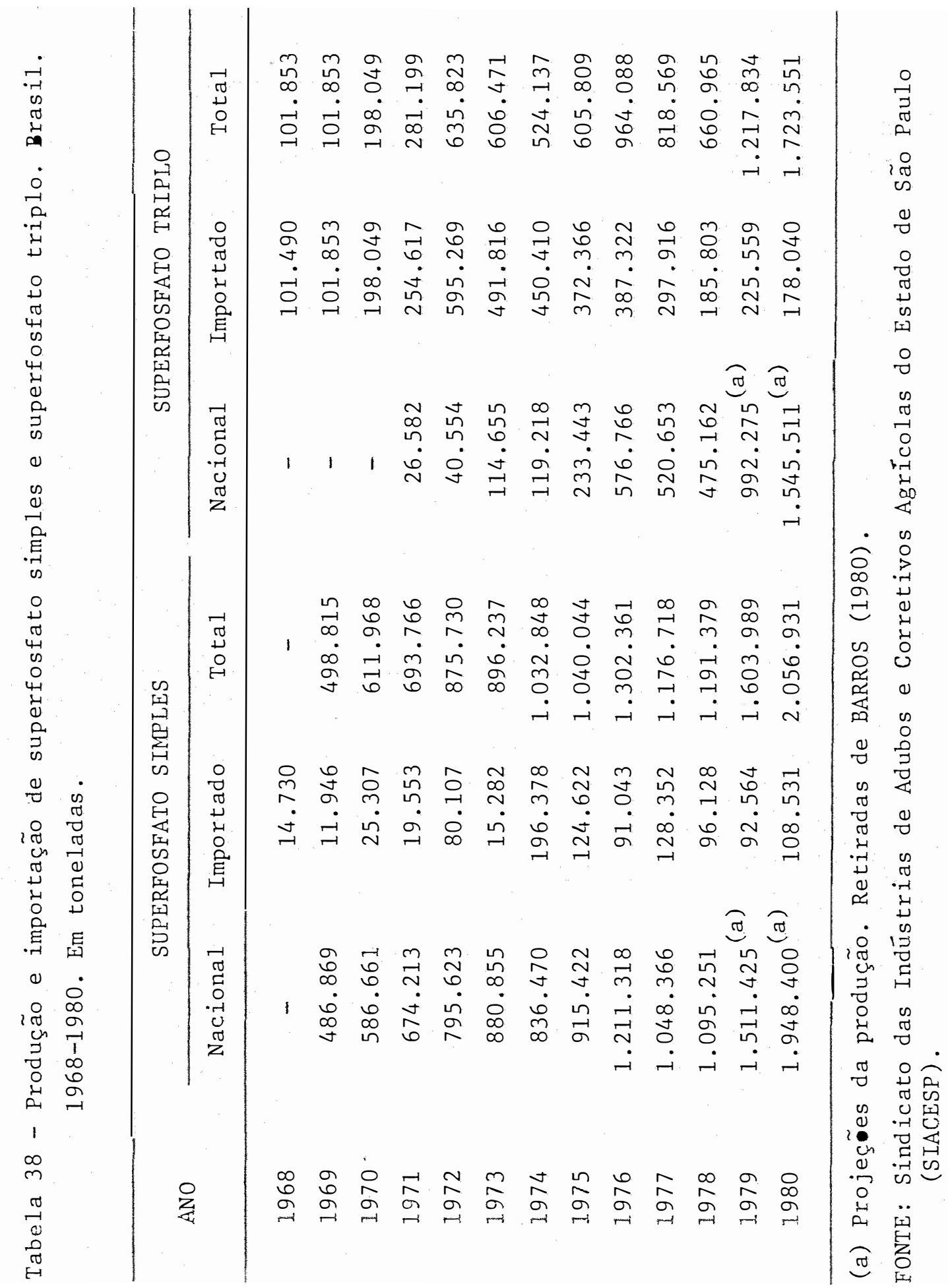


148.

Tabela 39 - Taxa de câmbio ponderada. Brasil. 1968-1980.

\begin{tabular}{lc} 
ANO & CR \$ /US $\$$ \\
\hline 1968 & 3.409 \\
1969 & 4.076 \\
1970 & 4.594 \\
1971 & 5.282 \\
1972 & 5.934 \\
1973 & 6.126 \\
1974 & 6.790 \\
1975 & 8.126 \\
1976 & 10.670 \\
1977 & 14.138 \\
1978 & 18.063 \\
1979 & 26.870 \\
1980 & 52.699 \\
\hline
\end{tabular}

FONTE: Conjuntura Econômica - FGV. 
Tabela 40 - Consumo base de óleo diesel em um dia máquina. 1970-1979.

\begin{tabular}{ll}
\hline ANO & LITROS DE OLEO DIESEL \\
\hline 1970 & 55 \\
1971 & 55 \\
1972 & 56 \\
1973 & 59 \\
1974 & 61 \\
1975 & 63 \\
1976 & 65 \\
1977 & 65 \\
1978 & 67 \\
1979 & 68
\end{tabular}

Nota: 0 consumo de óleo diesel por faixa de potência foi ponderado pela venda acumulada de tratores (Tabela 36), segundo as mesmas faixas de potência, para obtenção do consumo base em cada ano. 